Utah State University

DigitalCommons@USU

All U.S. Government Documents (Utah Regional U.S. Government Documents (Utah Regional Depository)

Depository)

1981

\title{
Geochemical Results from a Rock Geochemical Survey in the Mount Belknap Caldera Vicinity, Utah
}

Robert E. Tucker

William R. Miller

J. N. Motooka

U.S. Geological Survey

Follow this and additional works at: https://digitalcommons.usu.edu/govdocs

Part of the Geochemistry Commons

\section{Recommended Citation}

Tucker, Robert E.; Miller, William R.; Motooka, J. N.; and U.S. Geological Survey, "Geochemical Results from a Rock Geochemical Survey in the Mount Belknap Caldera Vicinity, Utah" (1981). All U.S. Government Documents (Utah Regional Depository). Paper 564.

https://digitalcommons.usu.edu/govdocs/564

This Report is brought to you for free and open access by the U.S. Government Documents (Utah Regional Depository) at DigitalCommons@USU. It has been accepted for inclusion in All U.S. Government Documents (Utah Regional Depository) by an authorized administrator of DigitalCommons@USU. For more information, please contact digitalcommons@usu.edu.

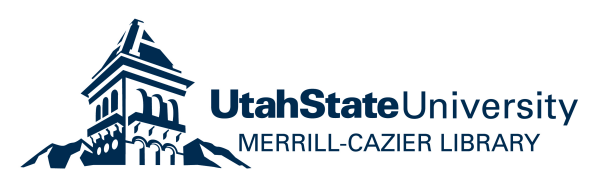




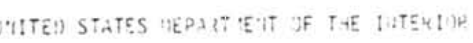

GEOLOGICAL SHQVEYY

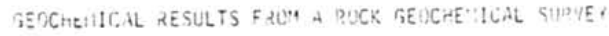

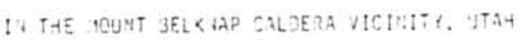

$\therefore y$

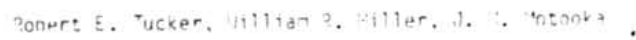

Cuen-File Pasor: 31-573

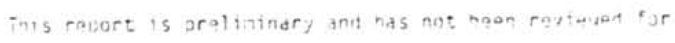
contarilty with U.S. Feolopical Survey editoride stancar:s. 

Rock, stream-sedinent, and hydrogeochemical surveys were conducted th the Mount Belknad c.ldera ared, south-central Utah, during the sunner of 1979. The presence of leucocratic rocks and relatively nith concentrations of the elements $v_{b}$, Be, Gd, Y, Ps, Sn, Mo, and F with corresponding low concentratio.1s of the elements $\mathrm{3a}, \mathrm{Mg}, \mathrm{Ca}, \mathrm{Fe}, \mathrm{Sr}$, and $\mathrm{Cu}$ suggests that late onase, hichly differentiated felsic magmas were int ruded and(or) erubted in the caldera vicinity. The presence of $y_{0}$ and $s_{n}$ in the rocks and $=$ in the water samoles suggest that the ore elenents were concentrated, first in residual fluids in the nadma and possibly later th aptgenetic ineral deposits. The data sugqest several target areas for further exploration.

\section{ACKNONLEOGMENTS}

J.F. Guadagnol, and J.D. Tucker ussisted with the sample collection and

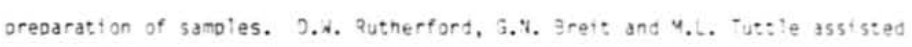
with the statistical analysts. O1scusstons with T.A. Steven, C.A. Cunntughan and J.0. Tucker on the geology and geochentistry of the area were ext-ere', heloful. 


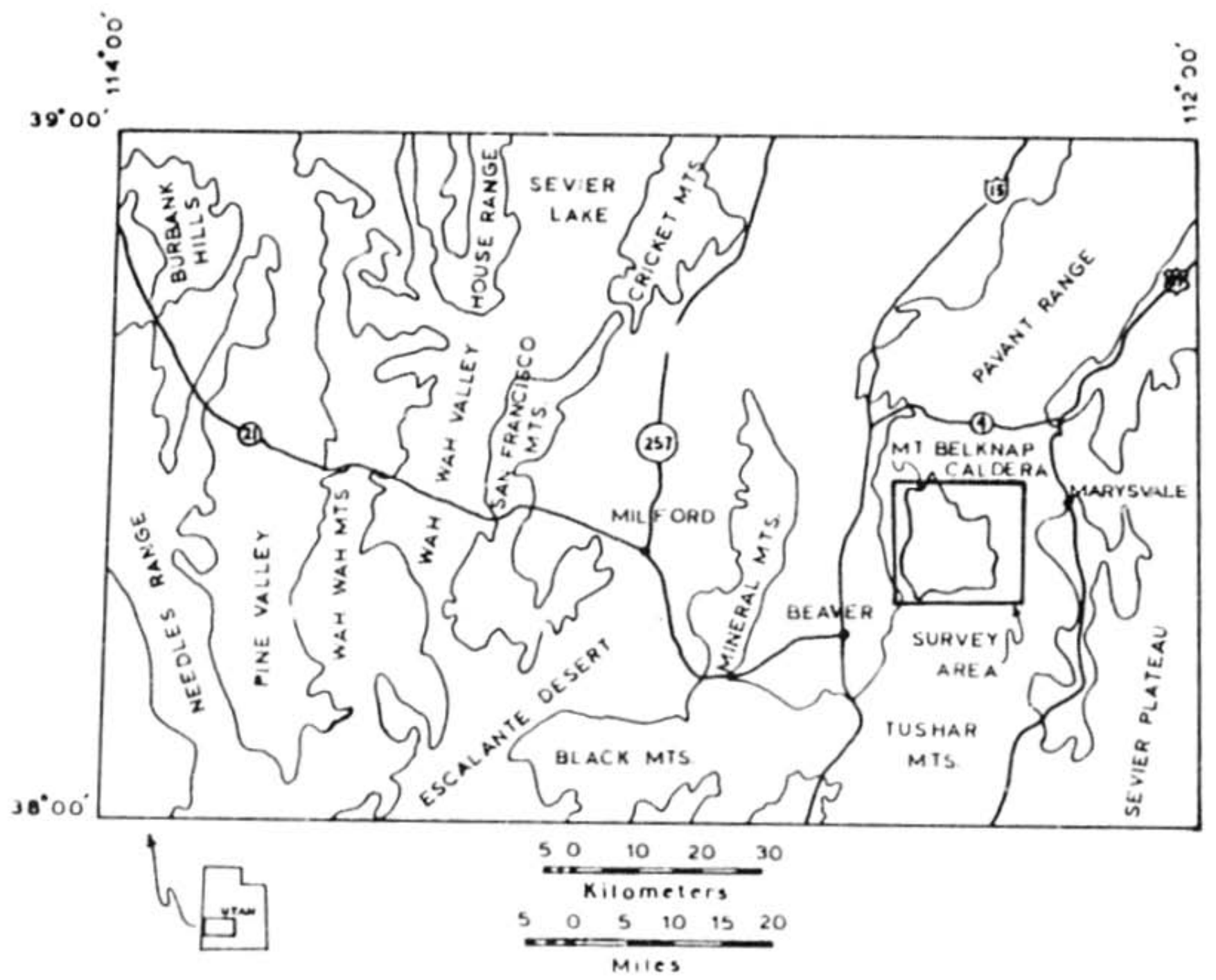

Figure 1... Index map of the Mount Belknap calderd survey ared, from the Richileld $1^{\circ}$ by $2^{\circ}$ quadrangle, Utah. 



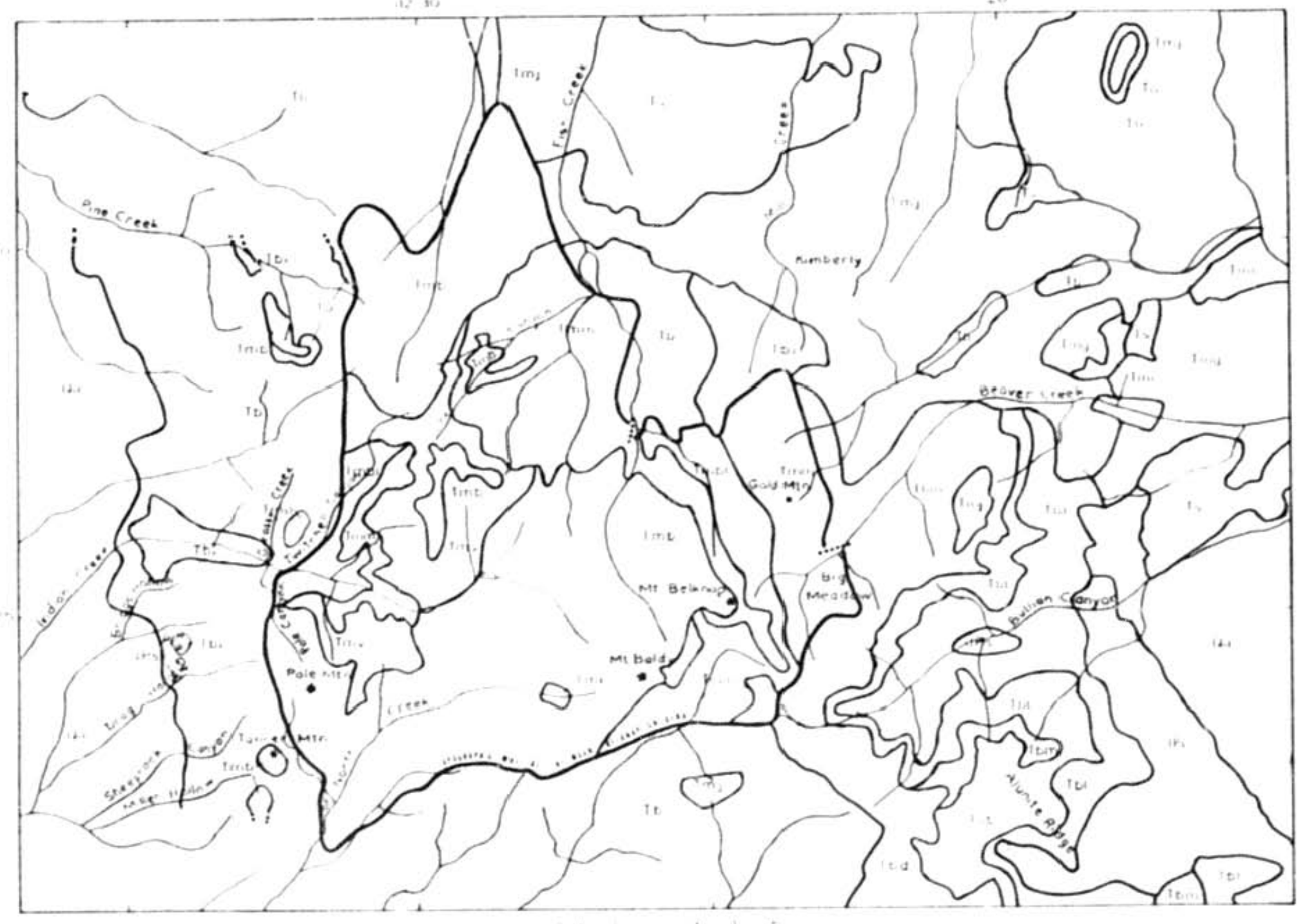


DESCR:PTION OF MAP UN:TS

ALLUVIAL DEPOS:TS (HOLOCENE)---5t1:s, sands, and grave's in alluvial fans, alluvial slope rash, and strean alluvium. SEVIER z:VER BorMAT:ON, LONER OART (PLTOCEVE AND M:OCENE)-.-

fluvtatile gravels, sands, and sitt:s, wish intertayered ash-. fall tuffs

YOUNT BELKNAP YOLCANICS (MTOCENE) Interstue rocks--Several snall porohyrttic juar:z dattic to

Thyolitic stocks contatining scattered ahenocrysts of quar:z, glagtoclase, and saniline in a finely granular rosstc of alkali feldsgar and guartz

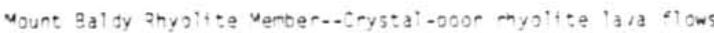

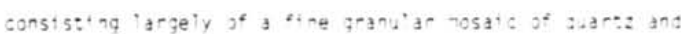

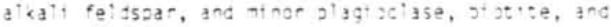
henative. Contored "low 'ayers are somon

Holcanislastic racks... Dominant ly lanaric nud-flow brecet as from hearoy lava tlows of the Mount 3aldy anyolite Member ("Tab). Some landstide sebrts and fluviatite sands and gravels are included

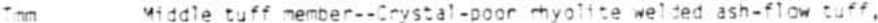
closely simlar :o that in the out flow joe Lot: Menber (" hy

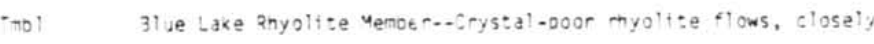

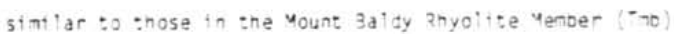

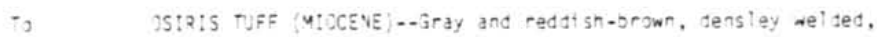
crystal-rich asn-flow :uff onenocrys:s constst of andesthe

(25 gersent), atotite ' 2 vercent), and : zercent each of

santdine, zymoxene, and Fe-"it axtces. A-ir age is about 22

$7 . y$. Fleck and ot ners :975:

7:LL:ON CANYON JOLZNVCS M:OCEVE AVD OL:GOCEVE

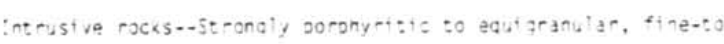

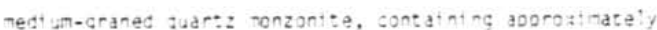
equal argoor tons of glagtociase and athociase, as tuch as

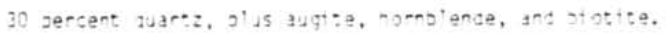

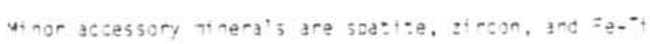
oxides

$r d$

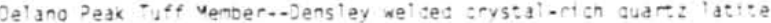

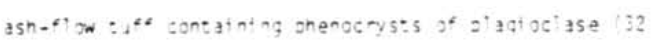

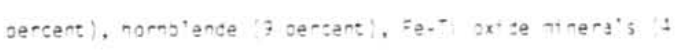

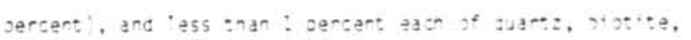
and aod: : 


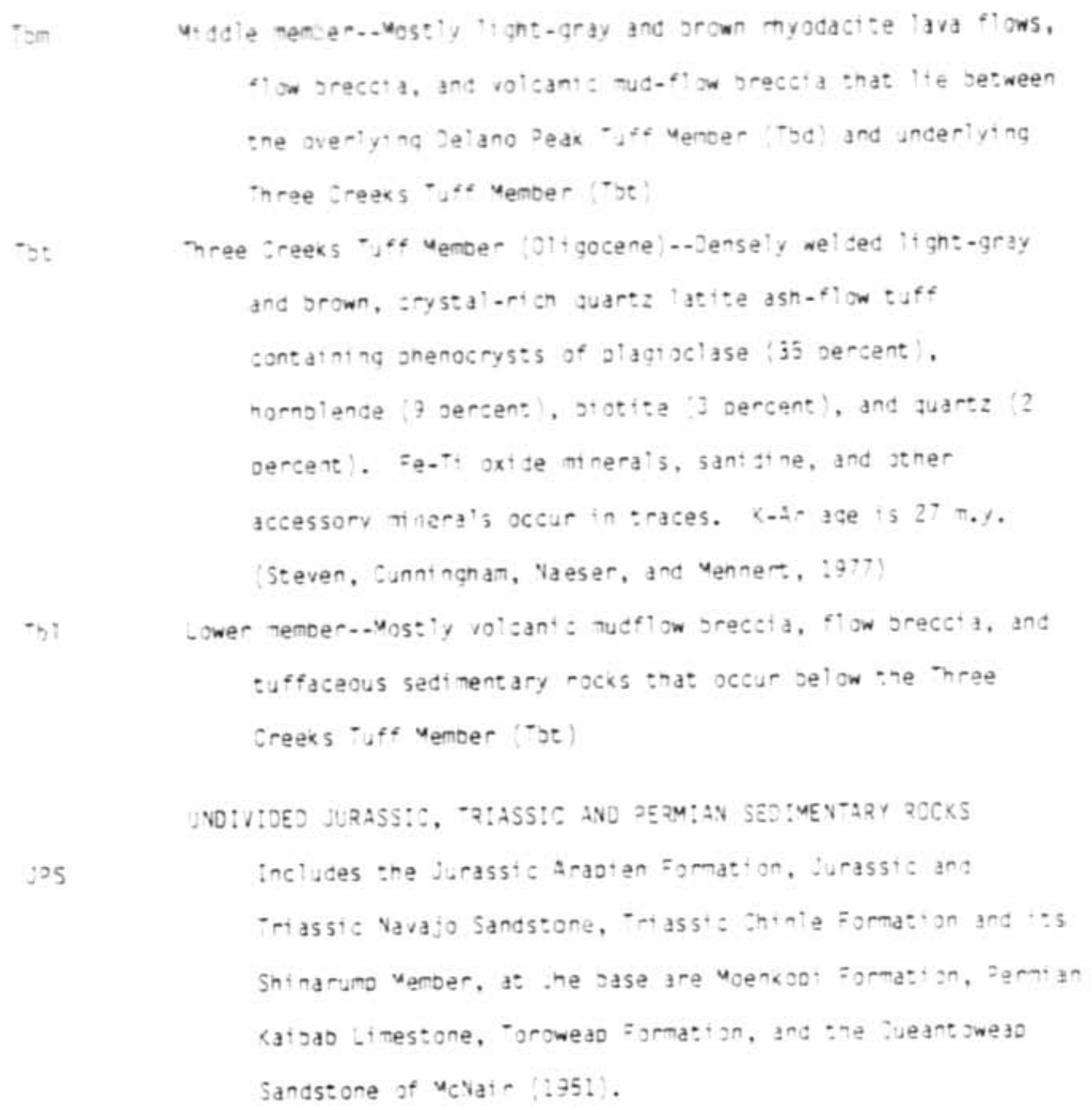

INDIVIDEO JURASS:C, -RIASS:C AND JEZM:AN SED:MEVTARY ROCKS 



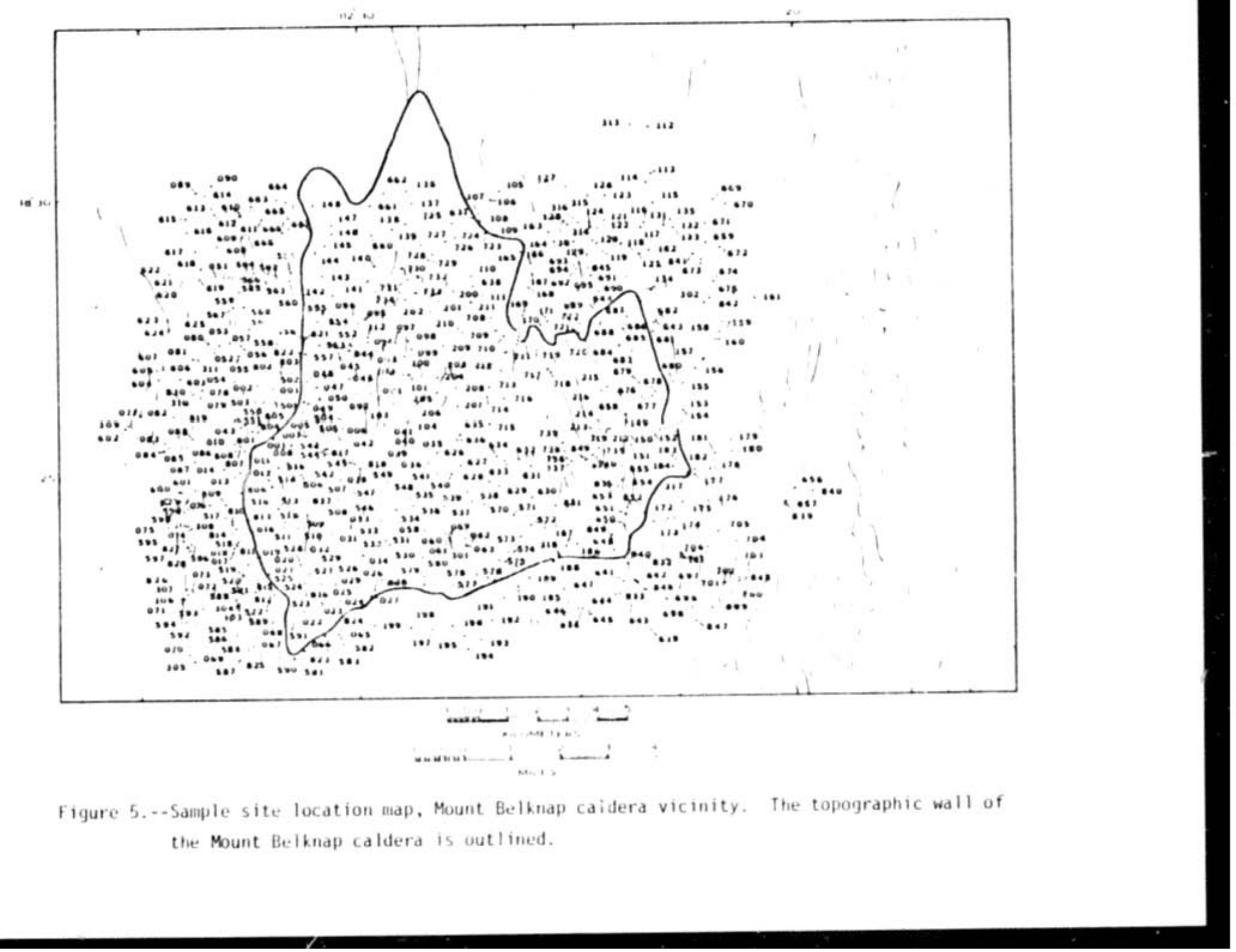


ddoining intervals on either side of the value 96 dercent of the time. The andivtical results for 22 elements are given in Appendix 1. Appendix 2 itsts etiont elenents which had fewer than $: 5$ detected concent rations. The andiytical resul:s cor the ojective samples are sumarized in table 3.

The variance within the sample set was analysed to determine the variance Jetween the different level; of the samoling desizn and to obtain a better inders:anding of the geochemtcal trends. The variance was analysed a: 5 levels. The airst level heasures the vartance be:ween the rnyolites and the ia:lies. The second leve: heasures the variance be: ween the 0.64 -square¿'lometer cel's, defined as the recional artance. The :hird level measures how we"' subcell samoles crom the same rock tyde redresent the combosition of the antire cell. The fourth ievel measures the variance that exists within a It ren sutcroo. The fifth level heasures the analytical rariance. Samoles usat in these dituerent andiyses of variance are itsted in table 4. Elament al concent rations :nat were de:ected but were less :nan :he terection itnit were given values equal to one iog interval below the tetection $1+71 \%$ Elemental concentrations :nat were not cetected were

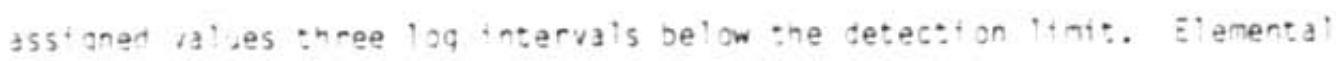
zoncentrations greater :nan the nithes: standard were as $5^{\prime}$ gned a vat ie one iog

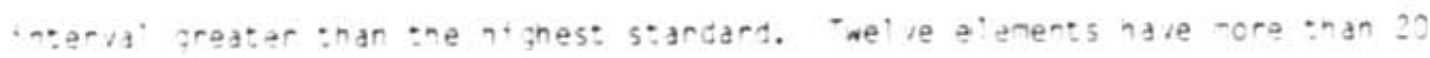
gercen: unqual, ried data and were used in the andigsts of vartance thof man and others, $19^{-9}$ ). The data were logarithmicaliy transformed ortor to

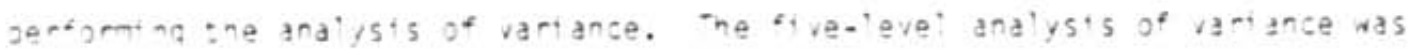

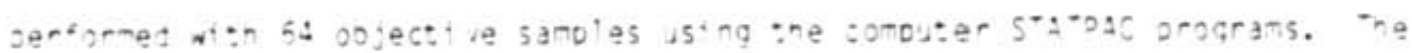
ariance zomoonents are shown on lable 5 and Fi jure 5.

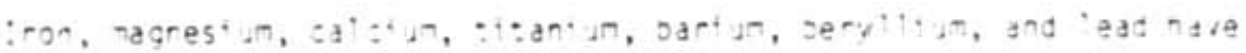

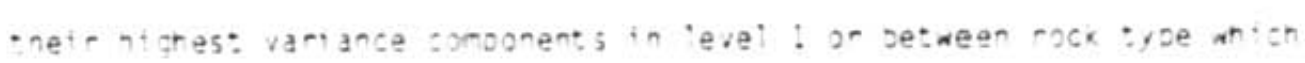


Table 3..- Sumary of andytical results for objective samples

\begin{tabular}{|c|c|c|c|c|c|c|c|c|c|c|}
\hline Elenent * & & Maximuai & Mean & $\begin{array}{l}\text { Geometric } \\
\text { mean }\end{array}$ & $\begin{array}{l}\text { Standard } \\
\text { deviation }\end{array}$ & $\begin{array}{l}\text { Geonetric } \\
\text { deviation }\end{array}$ & Valid* & L $\cdots$ & $N \cdots$ & G* \\
\hline fe 0.05 & 0.05 & 10 & 2.99 & 1.68 & 3.28 & 3.01 & 449 & 1 & 1 & 0 \\
\hline Mg $0.02=$ & 0.02 & 7 & 1.08 & 0.341 & 1.54 & 5.14 & 440 & 11 & 0 & 0 \\
\hline $\mathrm{Ca} 0.05=$ & 0.05 & 10 & 1.35 & 0.387 & 1.83 & 5.60 & 429 & $2:$ & 0 & 0 \\
\hline 110.002 & 0.01 & 1 & 0.466 & 0.313 & $\cdot \quad 0.375$ & 2.65 & 449 & 0 & 0 & 2 \\
\hline Mn 10ppai & 10 & 5000 & 667. & 464. & 562. & 2.73 & 448 & 1 & 0 & 2 \\
\hline Ay $0.5 p p=$ & 0.5 & 15 & 0.629 & 0.205 & 1.01 & 2.21 & 50 & 195 & 206 & 0 \\
\hline Ba 20ppai & 20. & 5000 & 640. & 223. & 794. & 4.90 & 436 & 13 & 2 & 0 \\
\hline He Ippan & 1. & 70 & 9.19 & 5.88 & 7.74 & 2.89 & 440 & 8 & 3 & 0 \\
\hline Сo 5 ppri & 5. & 70 & 12.3 & 3.10 & 13.2 & 4.26 & $: 78$ & 1 & 272 & 0 \\
\hline $\mathrm{Cr} 20$ pim & 20. & 500 & 46.3 & 21.7 & 80.5 & 3.12 & 194 & 107 & 150 & 0 \\
\hline Cu 5ppan & 5. & 100 & 19.1 & 5.72 & 22.2 & 4.89 & 210 & 90 & 151 & 0 \\
\hline Ia $20 p$ pin & 20. & 300 & 59.0 & 49.1 & 30.5 & 1.93 & 423 & 5 & 23 & 0 \\
\hline Mo 5 pinai & 5. & 20 & 5.78 & 2.07 & 2.20 & 2.50 & 150 & 37 & 264 & 0 \\
\hline Nb 20 pinta & 20. & 100 & 41.5 & 31.2 & 20.9 & 2.10 & 318 & 95 & 38 & 0 \\
\hline *1 5ppan & 5. & 100 & 14.8 & 5.57 & 18.6 & 3.74 & 160 & 190 & 101 & 0 \\
\hline $\mathrm{Pt} \quad 10 \mathrm{ppm}$ & 110. & 150 & 42.6 & 34.1 & 23.4 & 2.07 & 431 & 7 & 13 & 0 \\
\hline Sn 10ppmi & 10. & 15 & 10.0 & 4.08 & 0.235 & 1.55 & 24 & 129 & 298 & 0 \\
\hline Sr 100ppn & 100. & 2000 & 329 & 115. & 334. & 4.20 & 200 & 43 & 208 & 0 \\
\hline V 20pper & 20. & 500 & 97.1 & 22.1 & 98.1 & 4.28 & 172 & 29 & 250 & 0 \\
\hline Ү 10рри & 10. & 100 & 31.8 & 28.3 & 13.3 & 1.69 & 436 & 7 & 8 & 0 \\
\hline Zr 50ppen & 70. & 1000 & 222 & 207. & 99.4 & 1.45 & 451 & 0 & 0 & 0 \\
\hline Ga 10ppa & 10. & 70 & 29.4 & 26.2 & 10.9 & 1.73 & 433 & 1 & 17 & 0 \\
\hline
\end{tabular}




\begin{tabular}{|c|c|c|c|c|}
\hline \multicolumn{2}{|c|}{ Subcell duplicates } & \multicolumn{2}{|c|}{ Site cuplicates } & \multirow[t]{2}{*}{ And lytical dudicates. } \\
\hline Rnyolite & Latite & Rnyo: ite & Last:e & \\
\hline 035 & 017 & 040 & 153 & 059 \\
\hline 036 & 018 & 041 & 154 & 261 \\
\hline 044 & $\begin{array}{l}053 \\
057\end{array}$ & 121 & $\begin{array}{l}550 \\
551\end{array}$ & 263 \\
\hline 183 & 089 & 1,32 & 565 & 065 \\
\hline 184 & 614 & $13 ?$ & 566 & 175 \\
\hline $\begin{array}{l}204 \\
205\end{array}$ & $\begin{array}{l}173 \\
174\end{array}$ & $\begin{array}{l}531 \\
532\end{array}$ & $\begin{array}{l}593 \\
594\end{array}$ & $\begin{array}{l}130 \\
132\end{array}$ \\
\hline 510 & $\begin{array}{l}519 \\
520\end{array}$ & 736 & & 194 \\
\hline 211 & 5206 & & & 96 \\
\hline $\begin{array}{c}540 \\
541\end{array}$ & $\begin{array}{l}0606 \\
607\end{array}$ & & & 198 \\
\hline $\begin{array}{l}548 \\
\vdots \neq 19\end{array}$ & 512 & & & 210 \\
\hline 549 & $6: 3$ & & & 583 \\
\hline $\begin{array}{l}577 \\
573\end{array}$ & $\begin{array}{l}520 \\
621\end{array}$ & & & \\
\hline 732 & & & & \\
\hline
\end{tabular}

able $\mathbf{3} . .$. aruance comorents as zercentages of totat arrarce and the

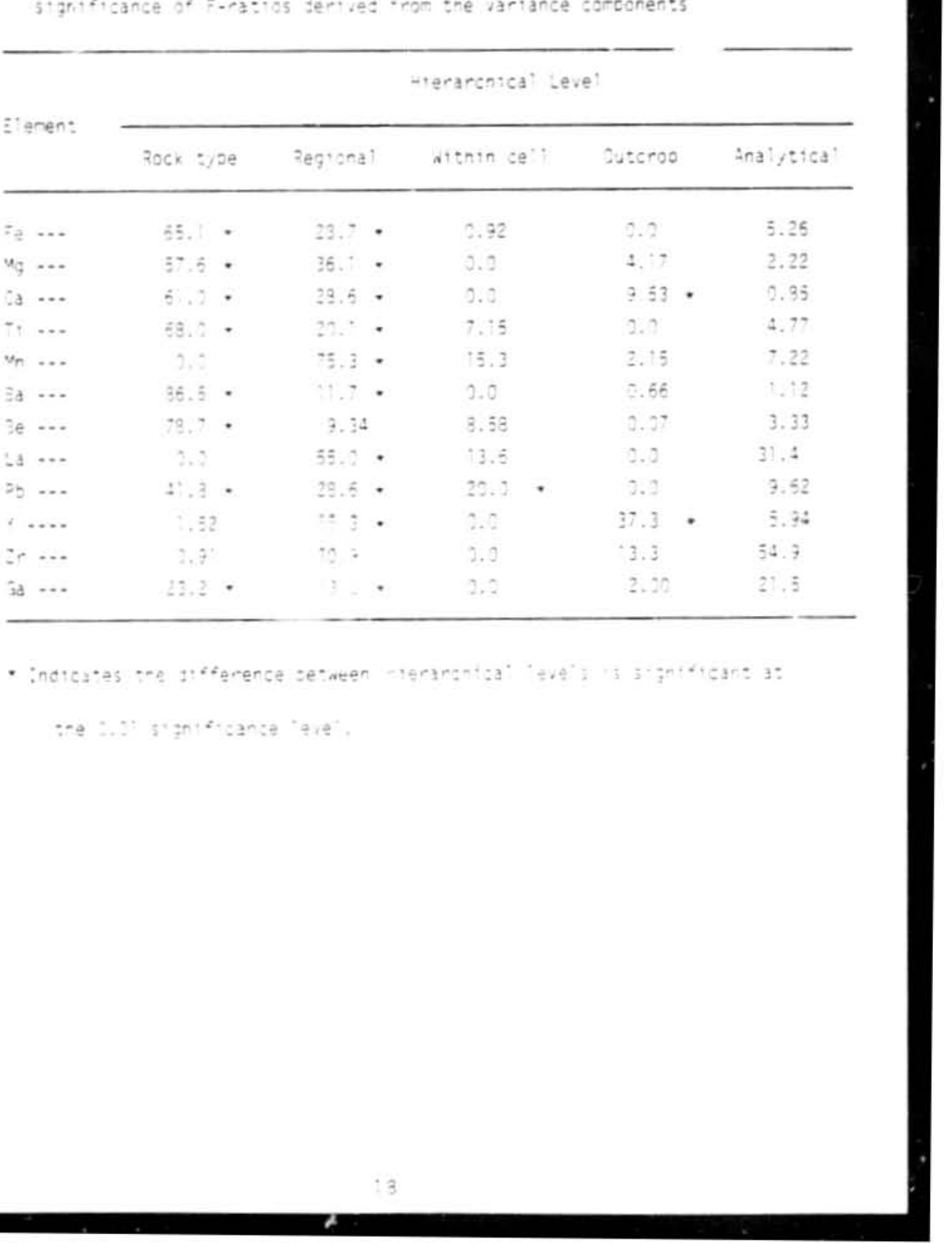




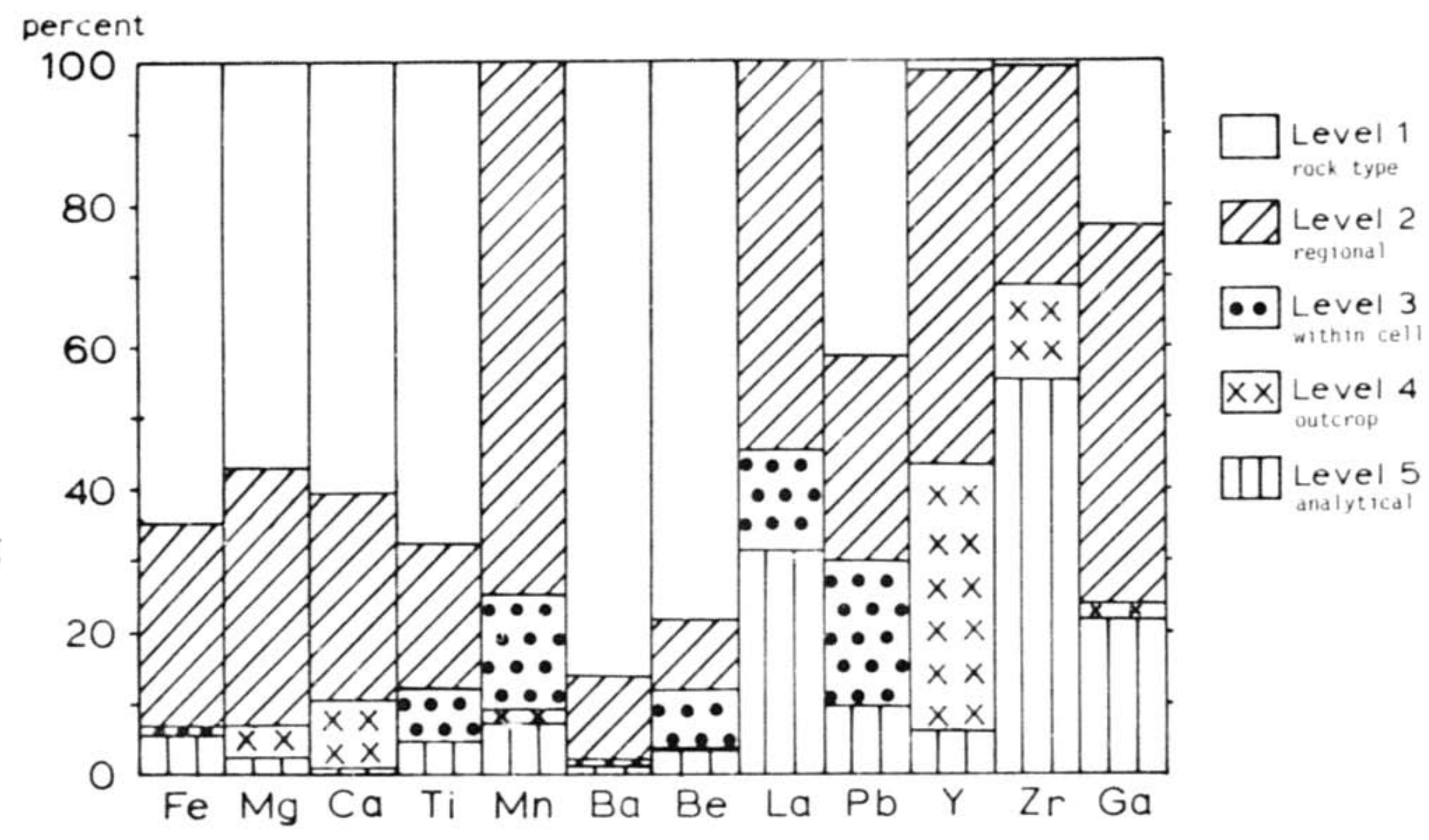

Figure 6... Graphical represenuation of the variance components between the hierarchical levels. 


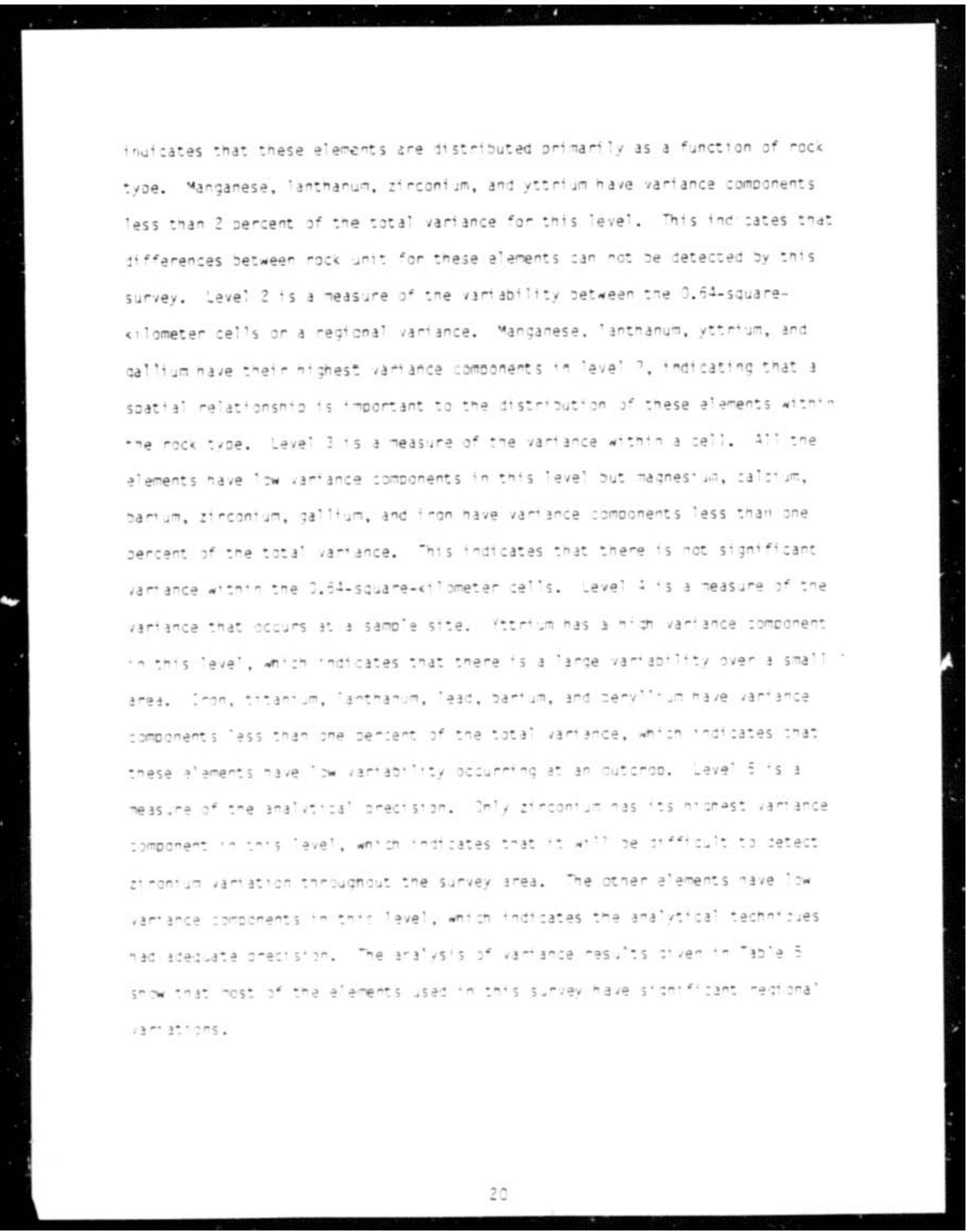


GEOCHEM.STRY OF THE ROCKS

Rock geochemistry can be useful in sineral exsloration and for gaining an uncerstanding of the geological and geochenical jrocesses that have :aken olace in an area. Careful geochemical studies of known porohyry-tyde molyodenum and : in deposits nave identiffed rany charactertst. aseful for exploration 'vallace and others, 1978; Sharo, :979; Sherator and alack, :973; 5illitor, Halls, and Grant, 19-5; Groves and McCarthy, :973; Groves and Tyylor, 1973; Van Alstine, 1975; Dagger, 1972; - - wenendorf, 1972: and Hosking, 1965). There are five indortant characteristics: (1) : nistory of volcantc andior) intrusive activity where rocks of leucocratic, alkalf anyoltitc or granitic composition are oresent; (2) Dresence of aronalous concentrations of

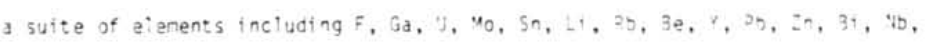
and $\mathrm{un}$; (3) the depletion of certain eleaents from the fagnd such as =o, Th, 3a, Sr, Yg, Ce, La, Al, Cu, and $2 r$, with subseguent aduct:y of dark ninerals:

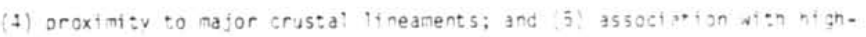
flourine delts. The zoronyry goiyodenum systams of zth rax, tencerson, .rad,

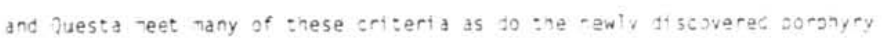
noiyodenum deposit at pine Grove in the van van "ountains, tan, and the ineralized areas associated with the vount 3eicnas calle-a ragt on being discussed here. Carest geologite ard geochemical stuctios concucted th the Yount Belknap caldera and around Aiunite Ridge by 5teven. Aunninghan, and Machette, (1980); Steven and Cunnthgham, (1979) and Cunninghan and Steven (1973b and $1978 c$ ) suggest :hat in thts area venatyoe urant dn depost:s fay be

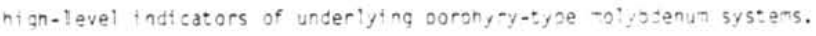

The degree to which the nineralizing solutions fed by lasifual aldts are

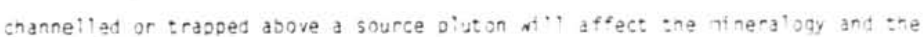
ayse of rineral deposits famed. Jebosition is controlled by factors such as gressure, themal Gradient, complexing fons, DH, and Ex swallace and others, 1978; ischendorf, 1972; and Hosking, 1963). The resuiting reactions commonily form concentration halues imprinted ont o a hos: rock; the form and extent of such haloes tedend an the complex tnteraction of such factors as (1) elemental concentrations, (2) thermal gradient and cooling ntstory, (3) wall rock nineralogy, and (4) degree of fracturing in the host rock (Groves thi Mccarhy, 1973; wallace and others, 1978; Jagger, 1972; Tischendorf, 1972; Hosking, :965, and Tucker and others, :93:). For porohyry molybdenum systems, rolybdentie is found in the central zone with consecuttvely larger naloes of 3i, Sn, and $A$ (wallace and others, :978). Figure $?$ depic:s tdealized alemental halo oatterns associated with the emolacement of a nighly differentfated leucocrat ic body containting significant concentrations of the elements yo and $\mathrm{sn}$. These naloes can express themselves as enrt rents of certain

elements and deolettons in other elements. The geochentical interrelationshios of these elements can be used to locate arnas of anomalousily iow

concentrations as wel' as areas of anomatousiy nith concentrations.

A correlation natrix is given in table 5 . The signiftcant corralation

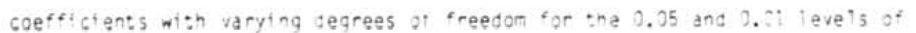
stantficance are given in able 7. Wo distinct suttes of eiements energe from the correlation natrix. The first suite consists of the elanents ib, $2 b$, $Y$, Ga, and Be which have significant correlation dt the 0.05 ievet with Mo. The second suite consists of the elements $\mathrm{ug}, \mathrm{Ca},{ }^{+}, \mathrm{un}, \mathrm{Ba}, \mathrm{Cr}, \mathrm{Cu}, \mathrm{Vi}$, and Sr which have significant correlation with Fe and the 0.05 level. Sn and ag have no significant comelation with any elements, which nay be at:-risuted :2 the small number of samples haying reasurable concentrations of these elements. The : wo suttes can also be distinuqished when sthqle-plerent diots are exaninec. Hign corcent rations of $\mathrm{vb}, 3 e, \mathrm{Gd}, \mathrm{v}, \mathrm{pb}_{\mathrm{b}}$, and sh are associatec 


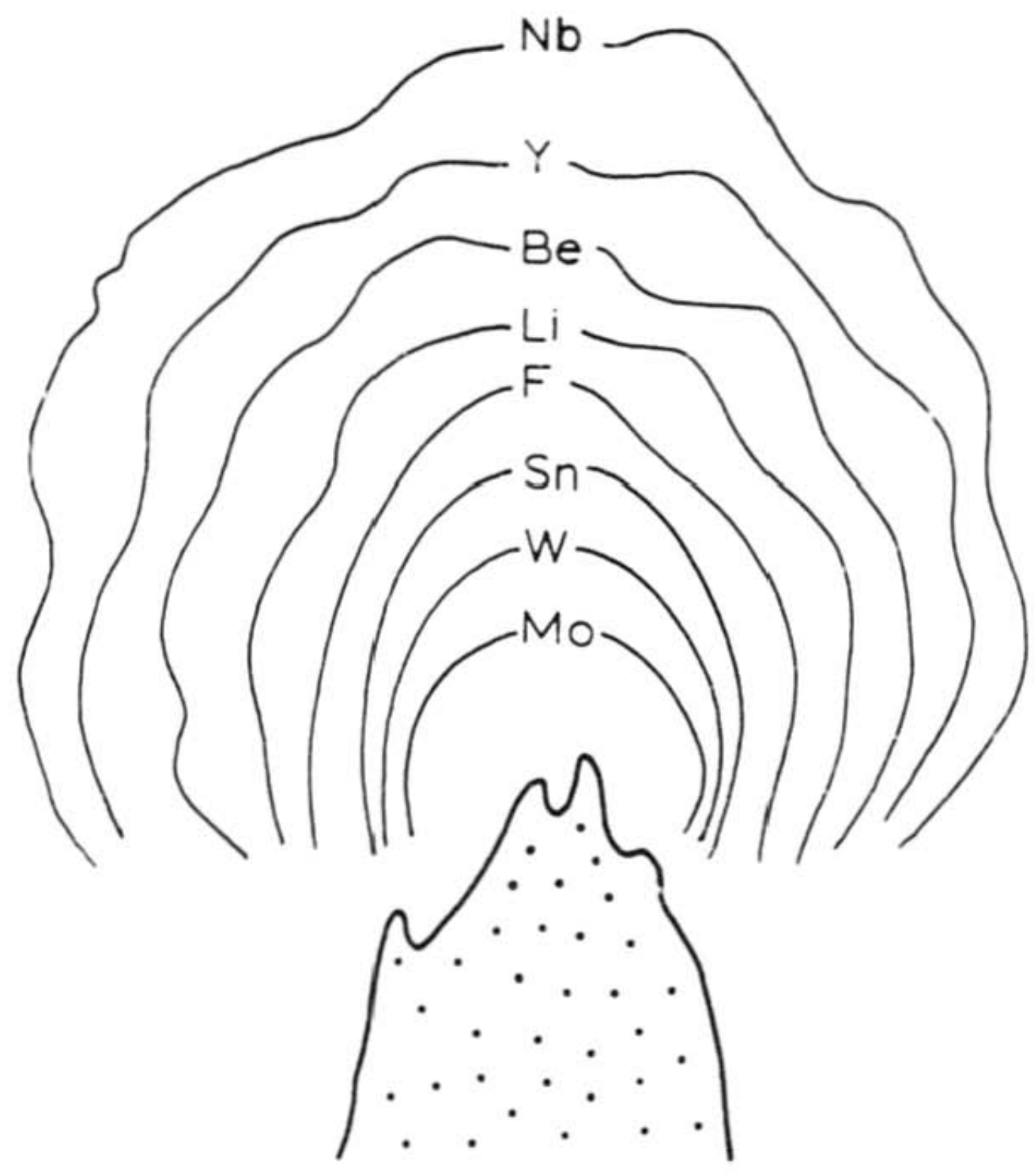

Figure 7.-.idealized cross section of elemen:al disterstor atcrg :merma gradients around an ore bearing feisic body. Sumarized from id liace and otmers (1979); Groves and MeCarthy (1978); and 7ischendorf 11973$)$. 
Tabie b...-Correlation coeffictents for rock data

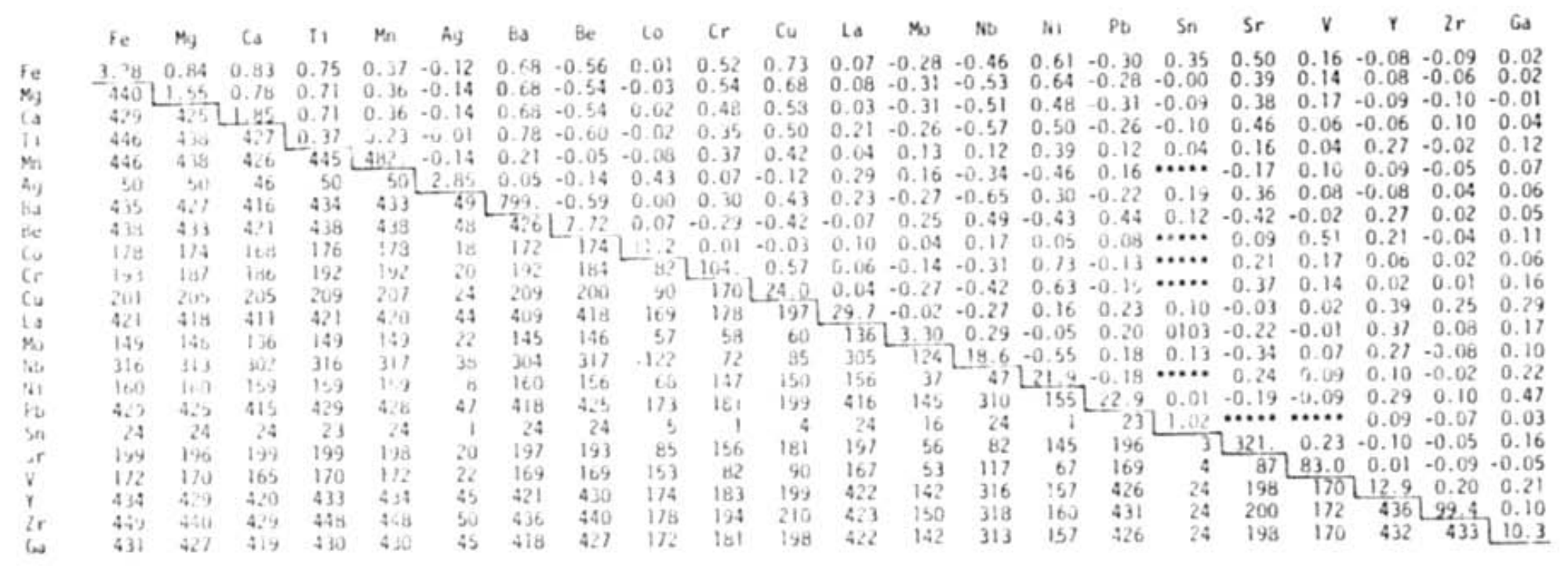

Hais. the diagual whierscored nusters of the correlation futrix contains the standard deviation of the variable for onily the valid pairs: the buters beiow the line detwie the valid pairs used in the correlation matrix calculations: .... denotes that no correlation

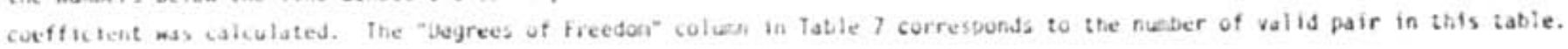




\begin{tabular}{|c|c|c|c|c|c|}
\hline $\begin{array}{l}\text { Jegrees of } \\
\text { Freedom }\end{array}$ & 5 & $1:$ & $\begin{array}{l}\text { Degrees of } \\
\text { Freedom }\end{array}$ & 5 & $1:$ \\
\hline 1 & .997 & 1.000 & 24 & 388 & .496 \\
\hline 2 & .950 & .990 & 25 & .381 & .487 \\
\hline 3 & .878 & .959 & 26 & .374 & .478 \\
\hline 4 & .811 & .917 & 27 & .367 & .270 \\
\hline 5 & .754 & .874 & 28 & .361 & .463 \\
\hline 6 & .707 & .334 & 29 & .355 & .456 \\
\hline 7 & .666 & .798 & 30 & .349 & .249 \\
\hline 8 & .632 & .765 & 35 & .325 & $\therefore 8$ \\
\hline 9 & .602 & .735 & 40 & .304 & .393 \\
\hline 10 & .576 & .708 & 45 & .298 & .372 \\
\hline 11 & .553 & .684 & 50 & .273 & .354 \\
\hline 12 & .532 & $.66 \mathrm{t}$ & 60 & .250 & .325 \\
\hline 13 & $.5 \%$ & .641 & 70 & .232 & .302 \\
\hline 14 & .497 & .523 & 30 & .217 & .233 \\
\hline 15 & .482 & .506 & 90 & .205 & .257 \\
\hline 15 & .468 & .590 & 100 & .195 & .254 \\
\hline$i 7$ & .456 & .575 & 125 & .174 & .229 \\
\hline is & .444 & .561 & 150 & .159 & .208 \\
\hline 19 & .433 & .549 & 200 & $\therefore z$ & .131 \\
\hline 20 & .423 &.$\$ 37$ & 300 & $\therefore 3$ & $\therefore 143$ \\
\hline $2:$ & .413 & .526 & 400 & .098 & $\therefore 29$ \\
\hline 22 & .004 & $.51 \lesssim$ & 500 & .288 & $\therefore ;$ \\
\hline 23 & .396 & .505 & 1000 & .262 & .281 \\
\hline
\end{tabular}

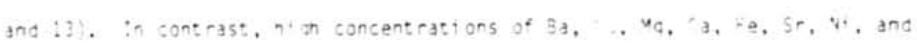

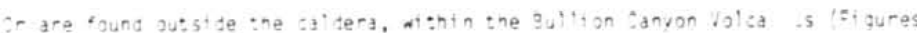

$: 2,: 5,: 5,: 7,: 3,: 9,20$, and $2: \%$. wolyodenun, $: 9,{ }^{4}$, and ta show no

setinte : rends latgurec 22, 23, 24, and 25 ! .

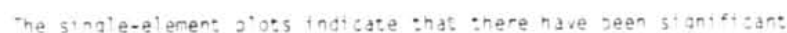

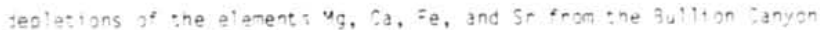

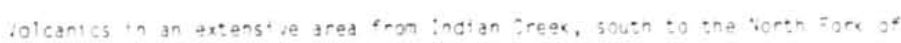

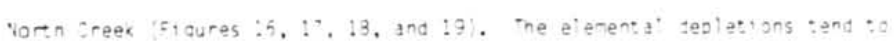

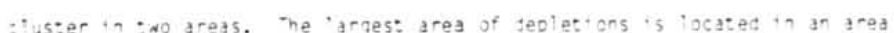

bardered ov grigas tollow an the north. Dote danyon on the eas: and zrag

Hollow on the south. His area is destignated the zray toll ow geochential

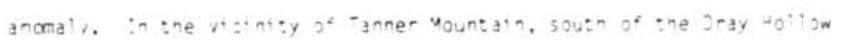

ceochentcal ancra', an anomat sus area bounses oy sneedock canyon an the

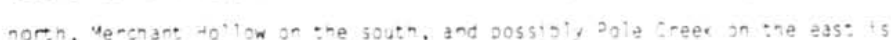

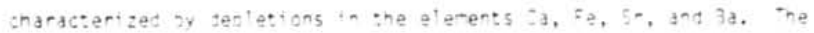

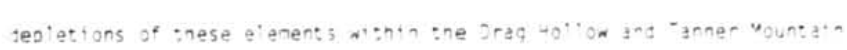

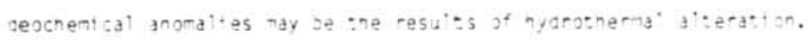

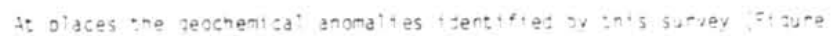

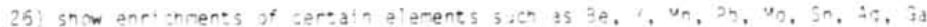




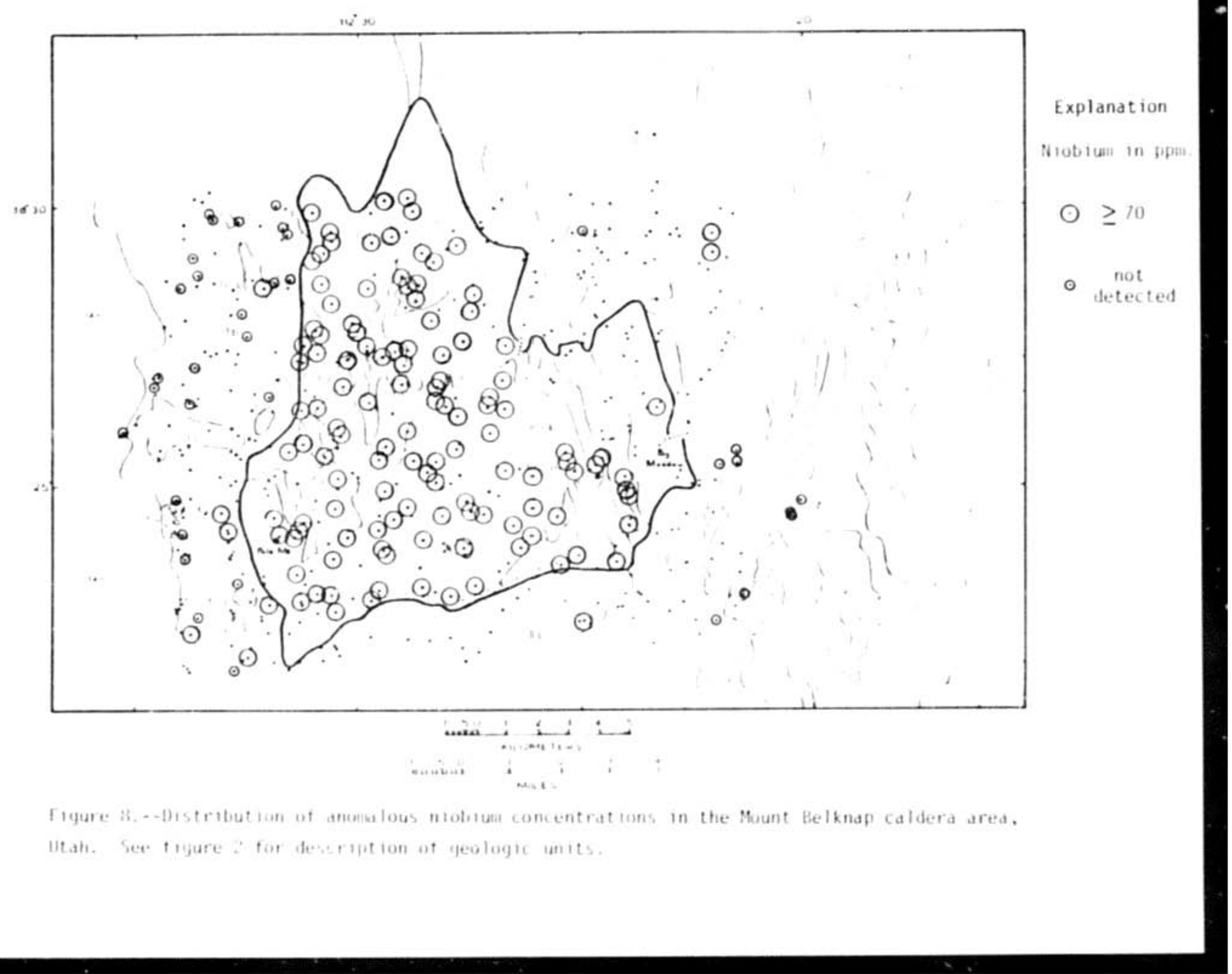




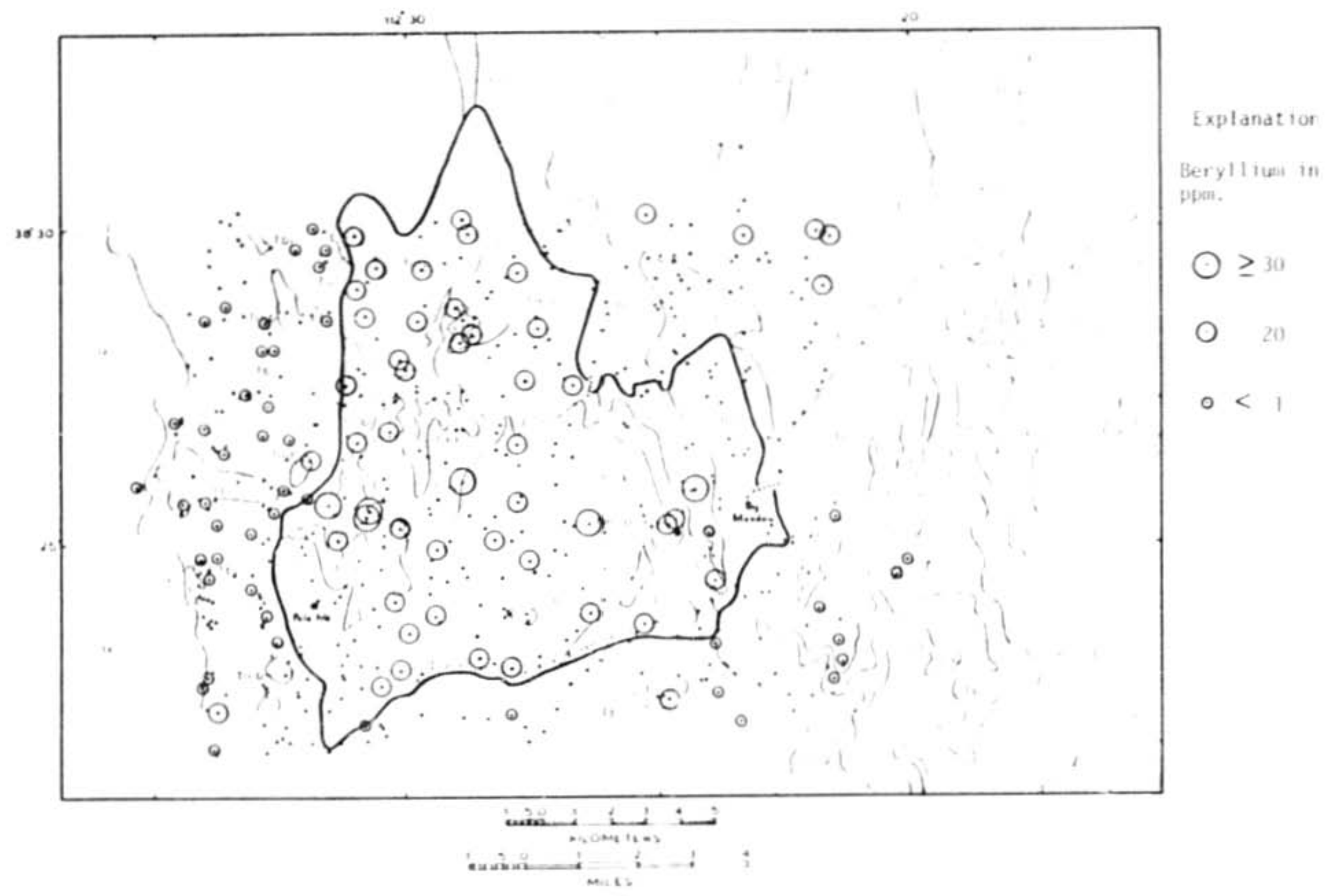

figure 9.-.Distribution of ancilalous beryllium concentrations in. the Mount Belbnaf caldera area, Utah. See tiqure? for descrimtion of geologic units. 


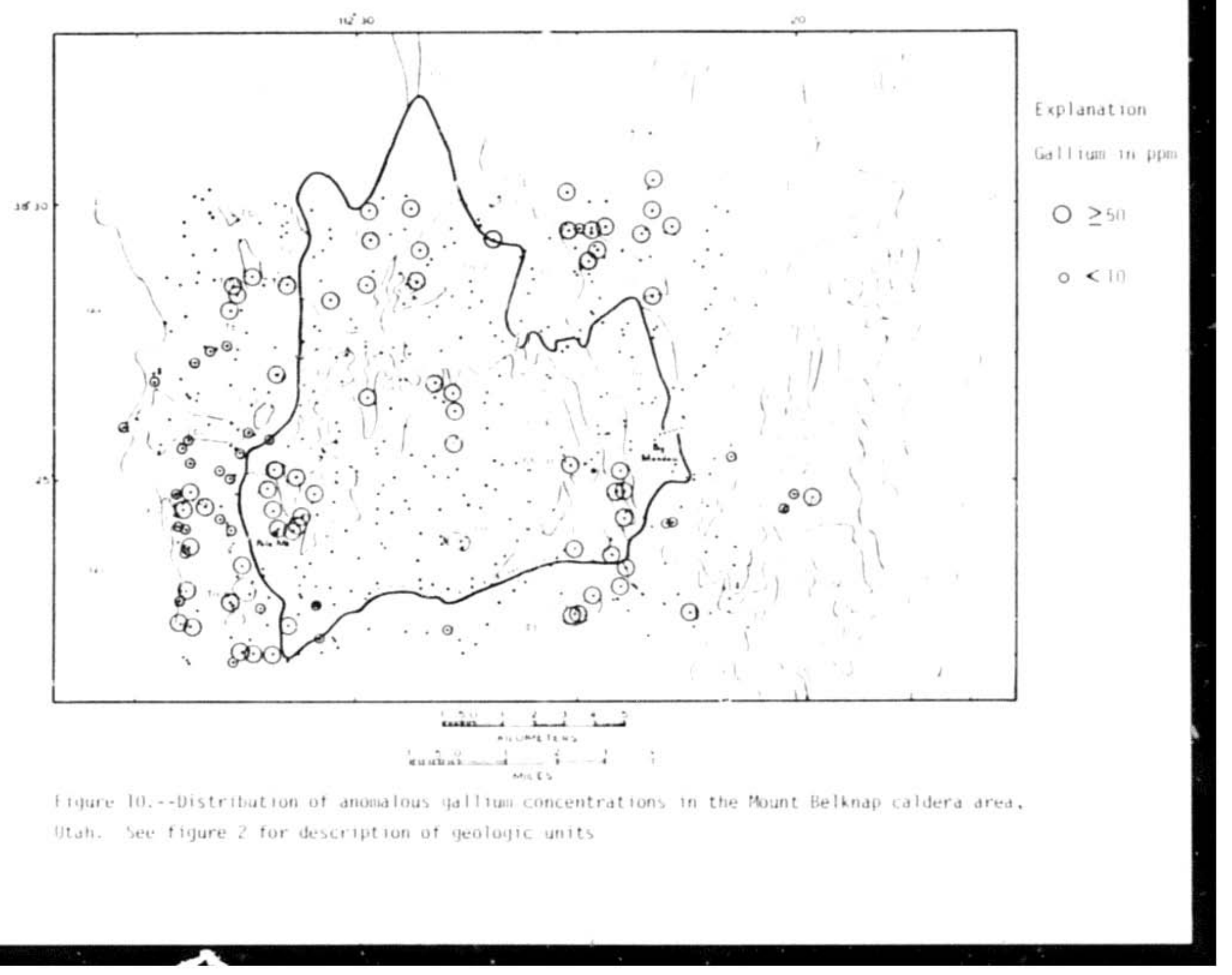




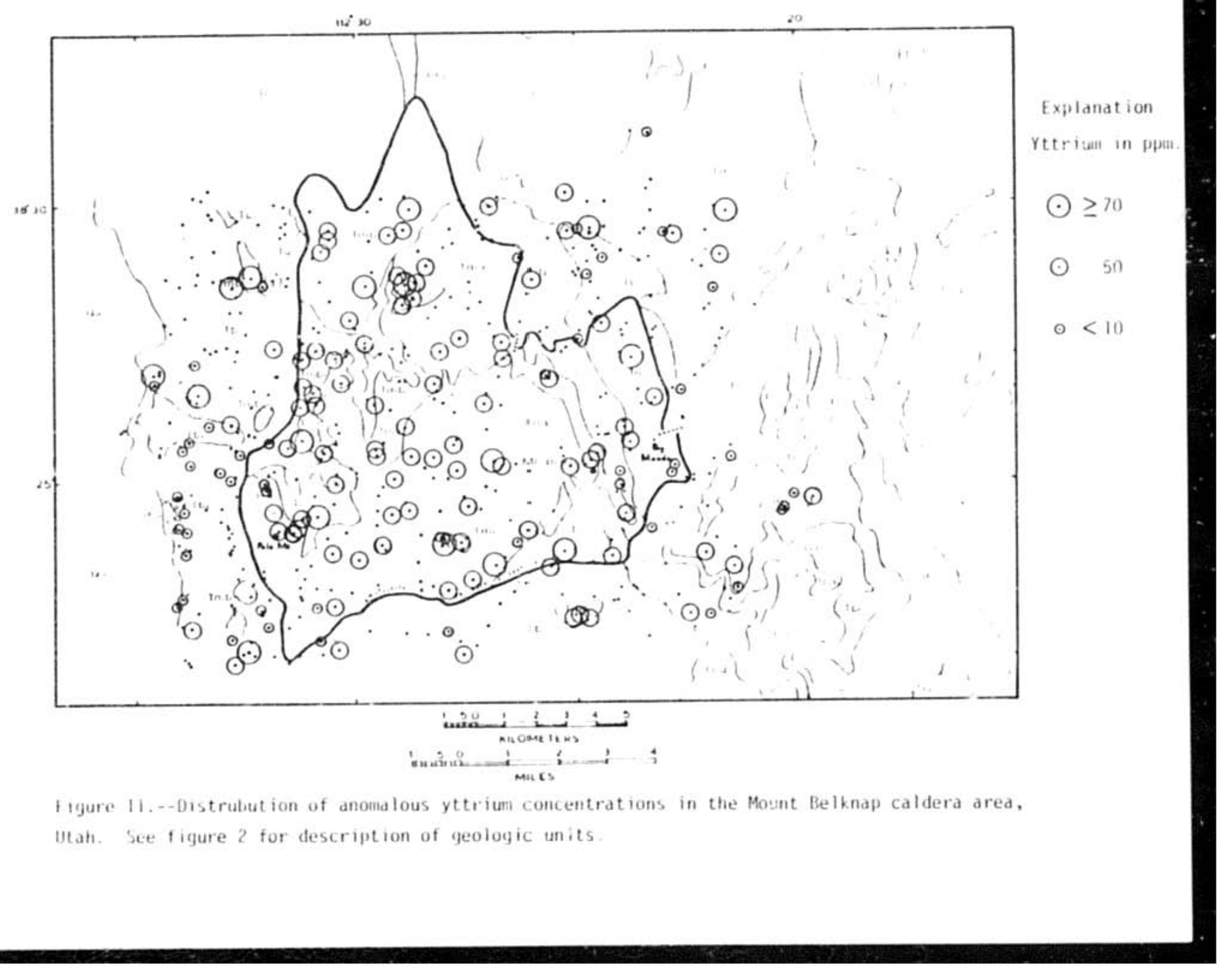




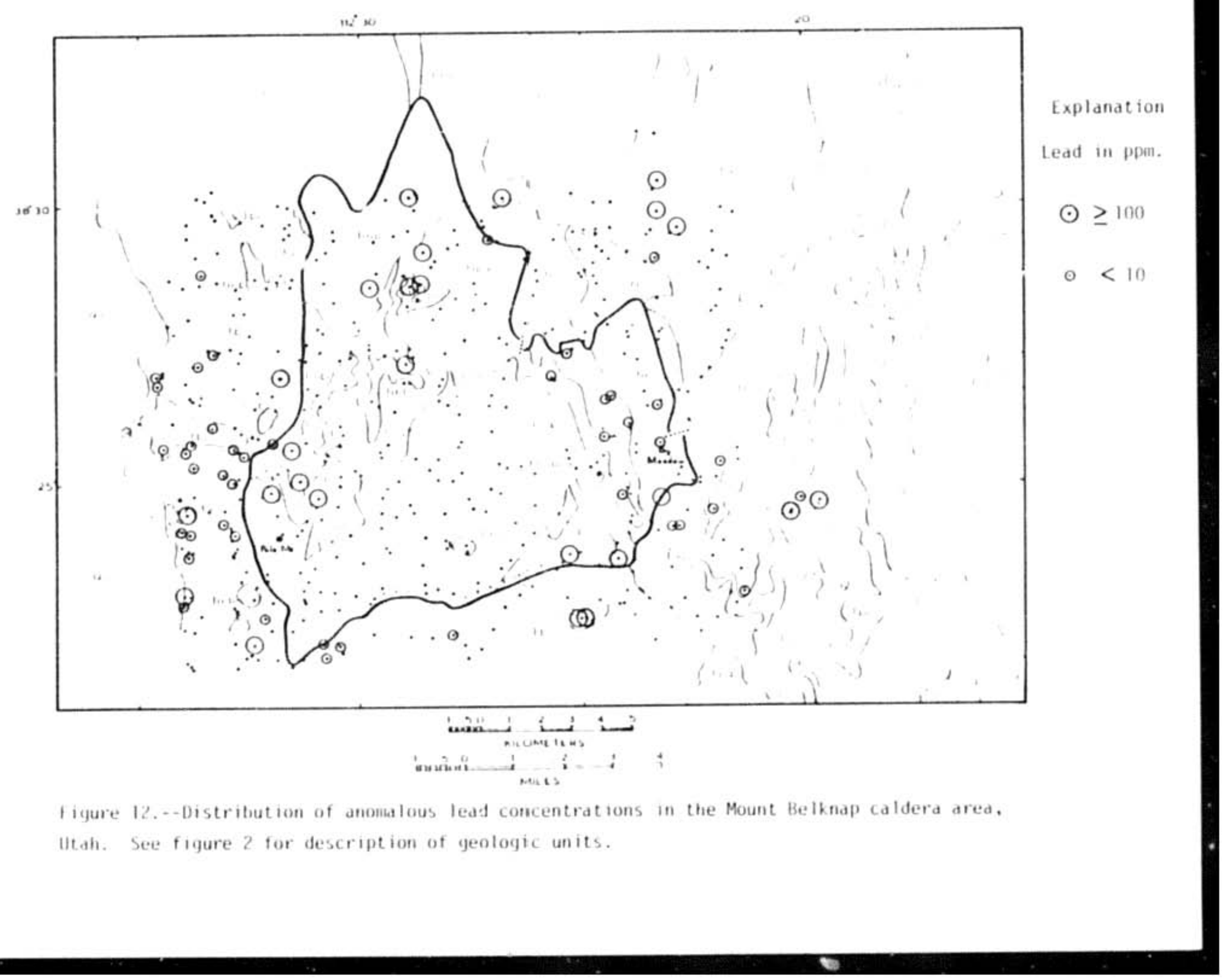




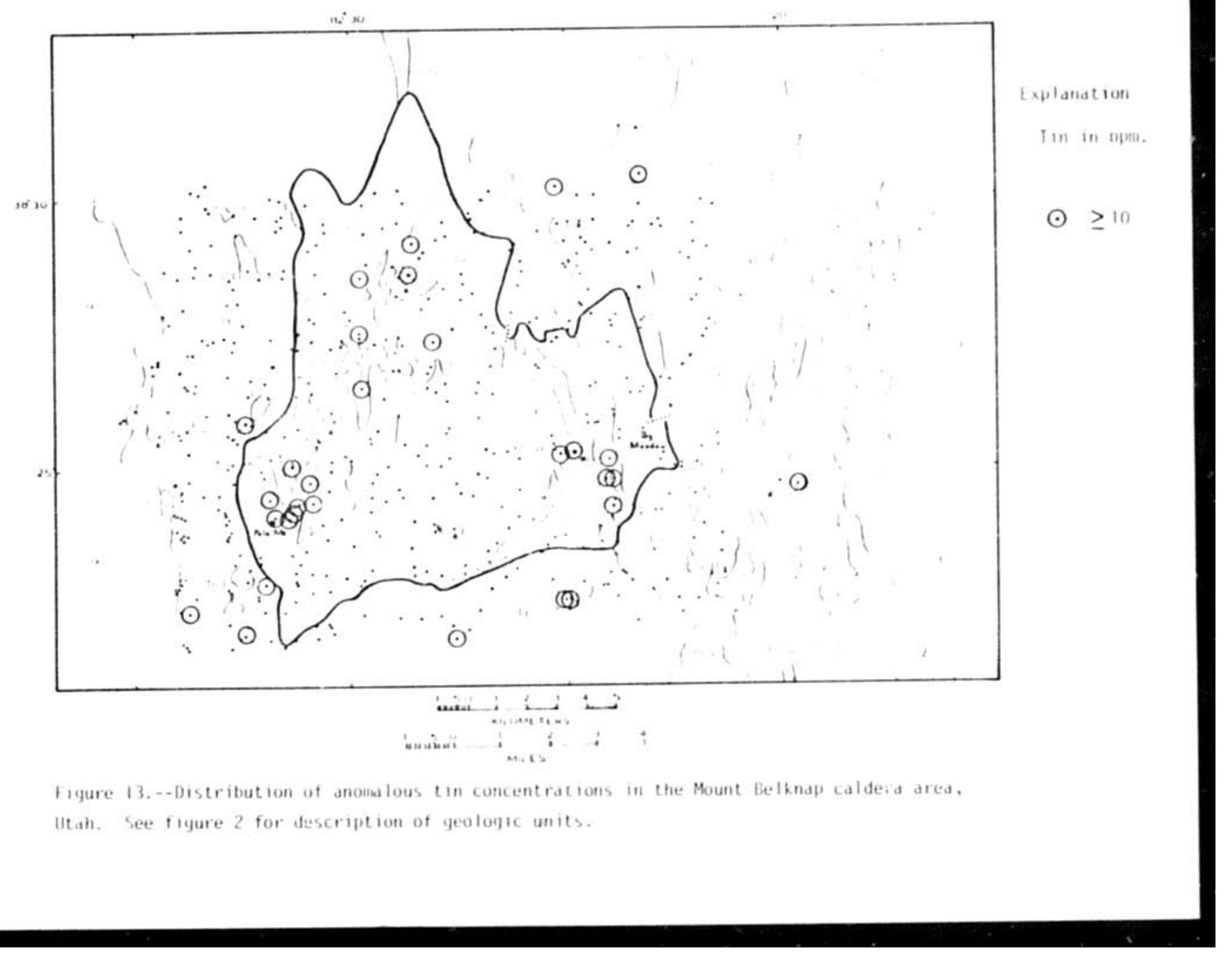




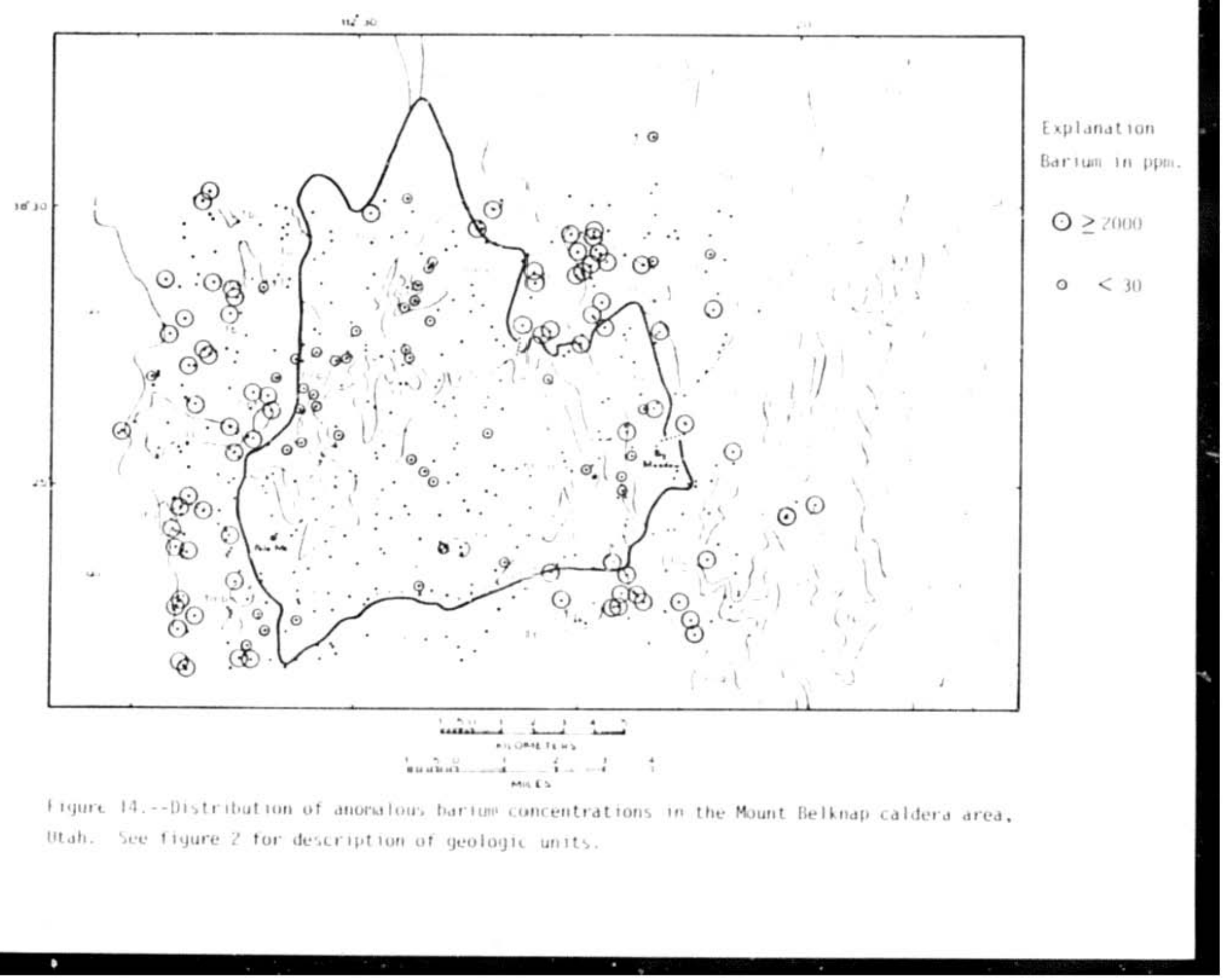




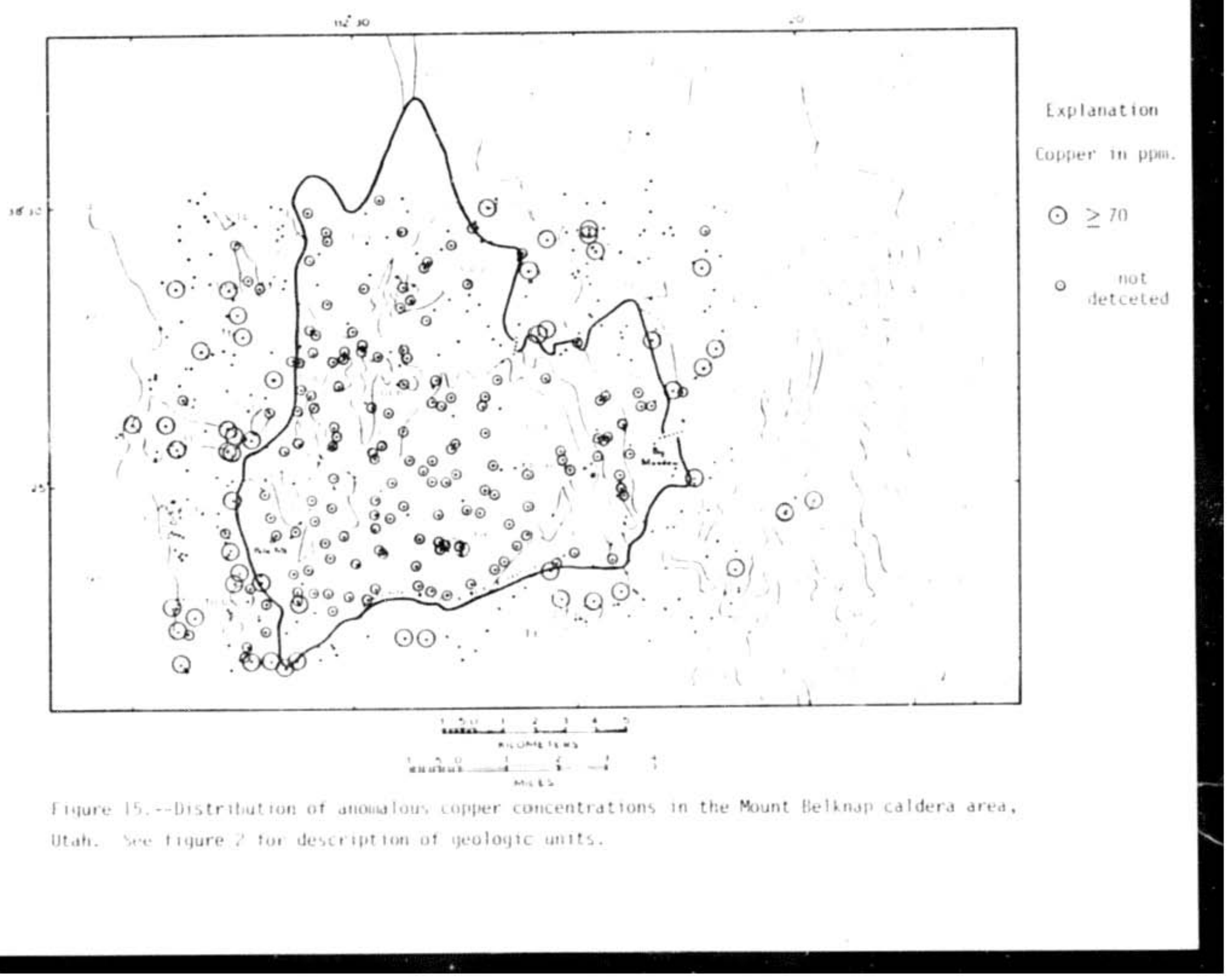




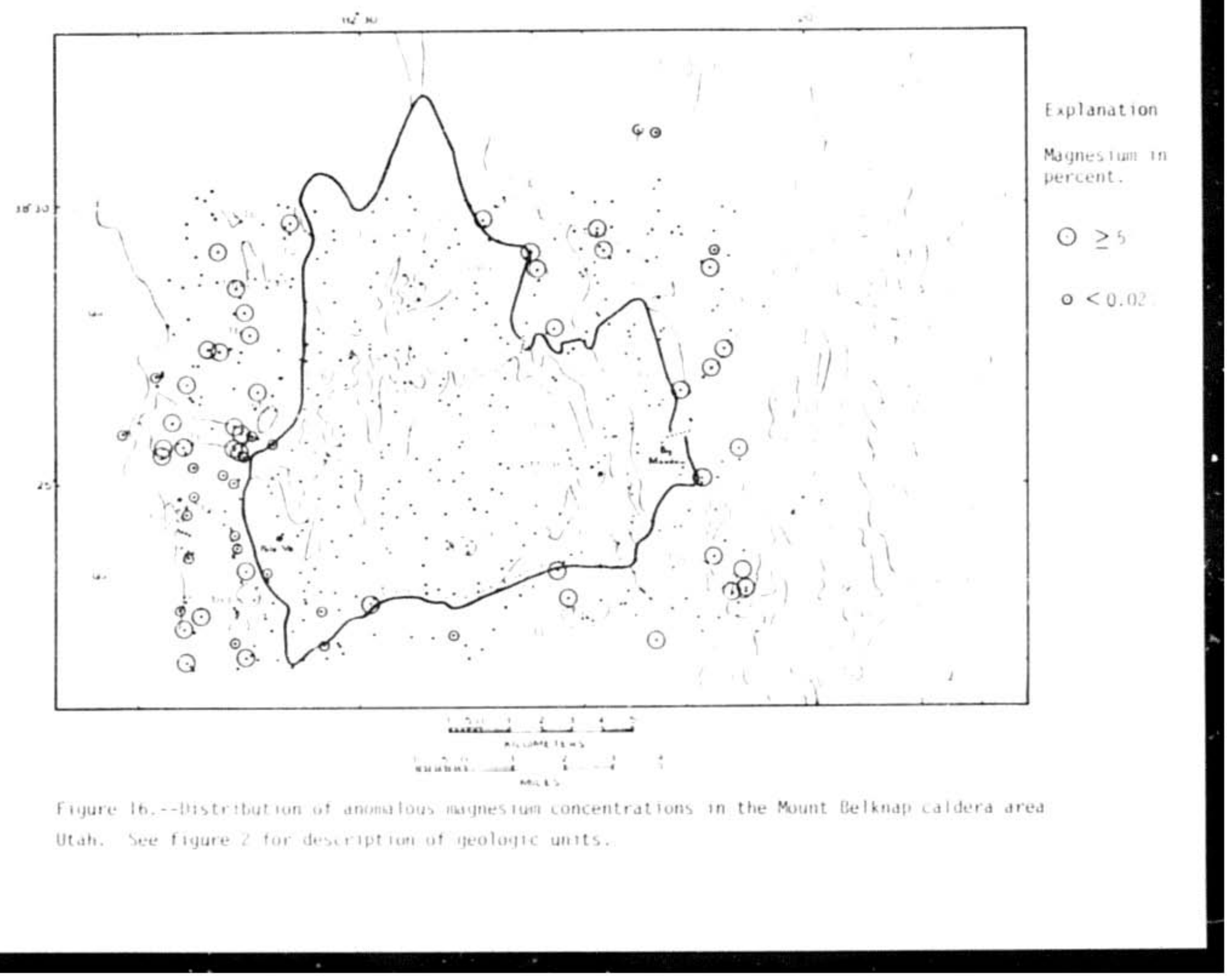




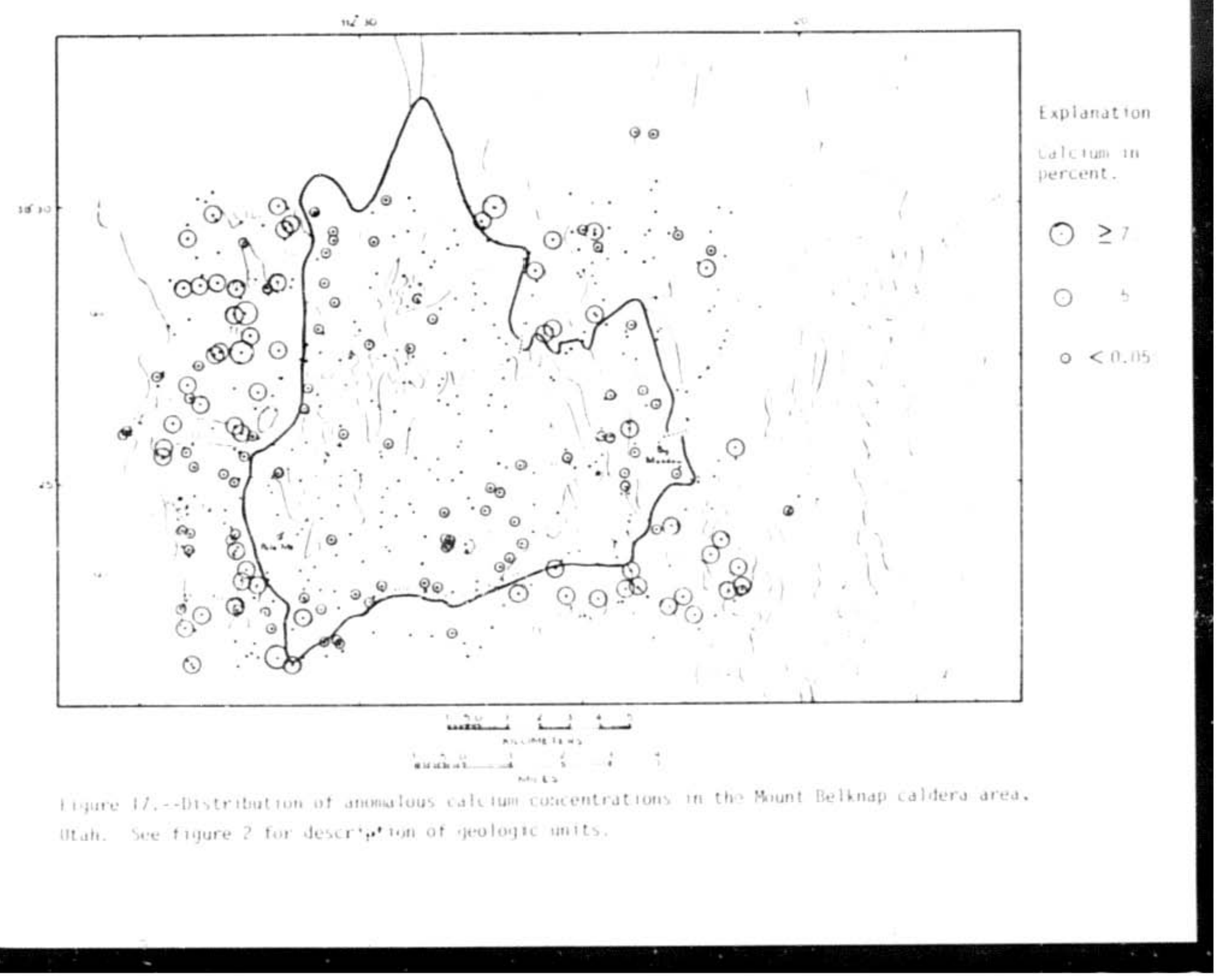




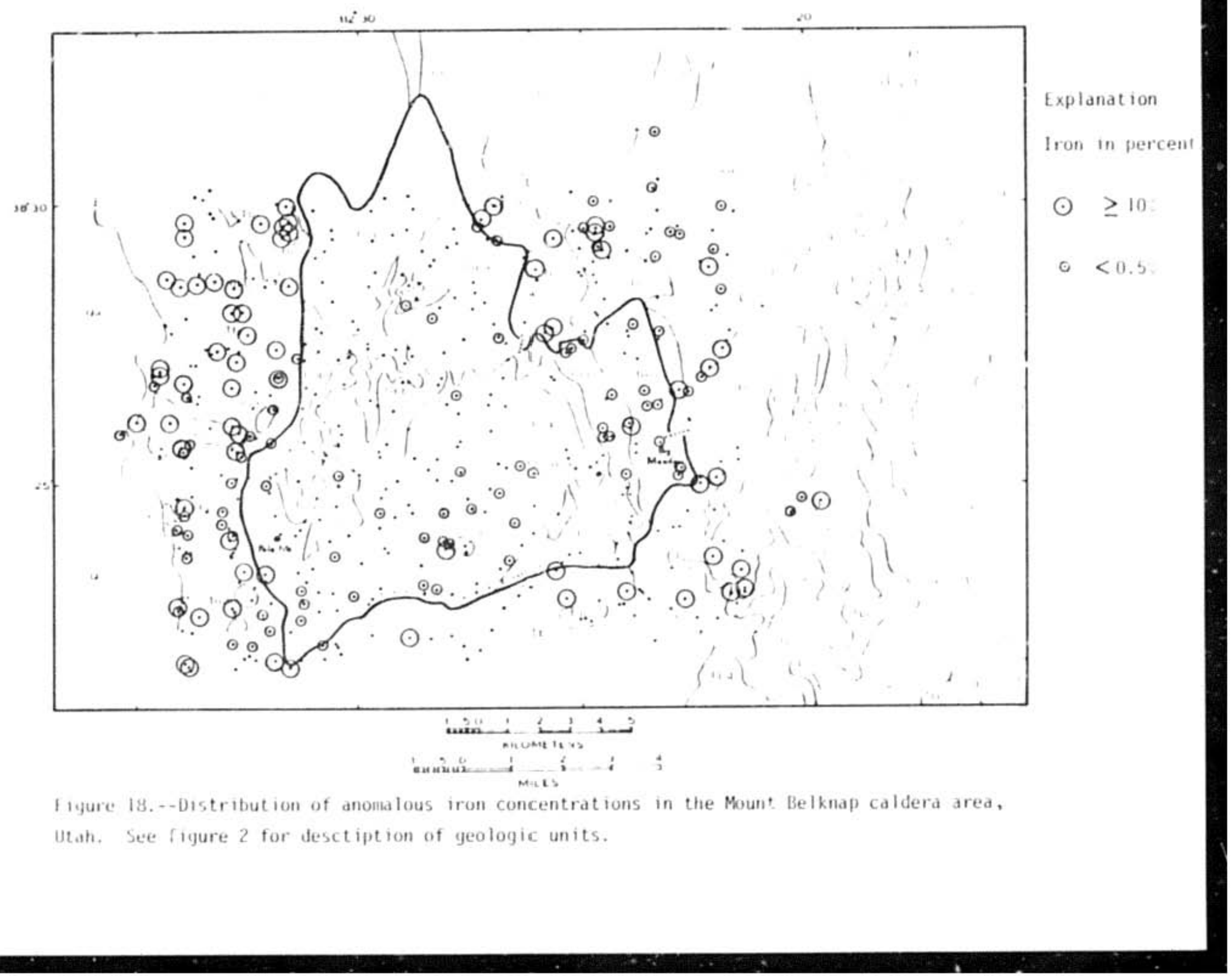




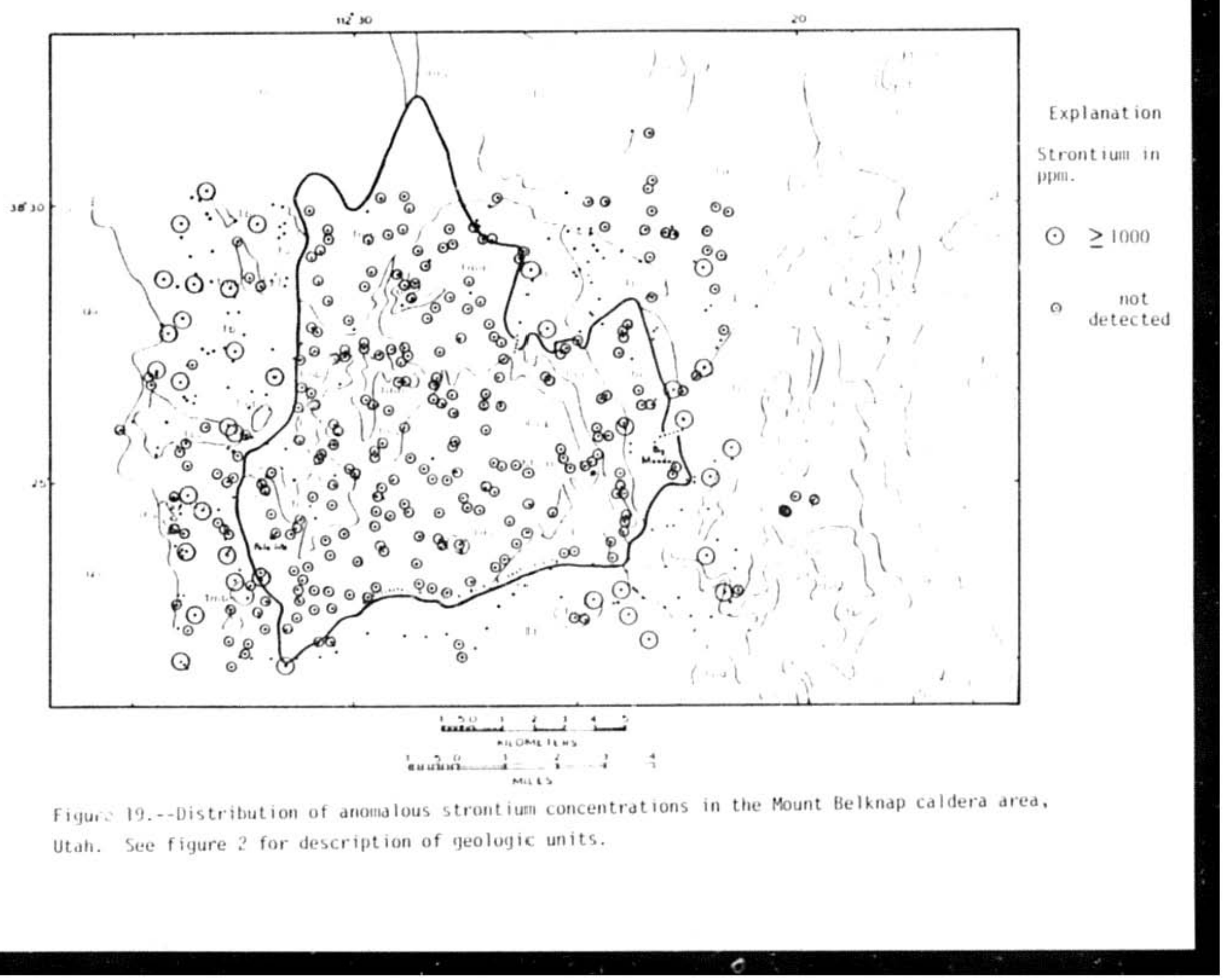




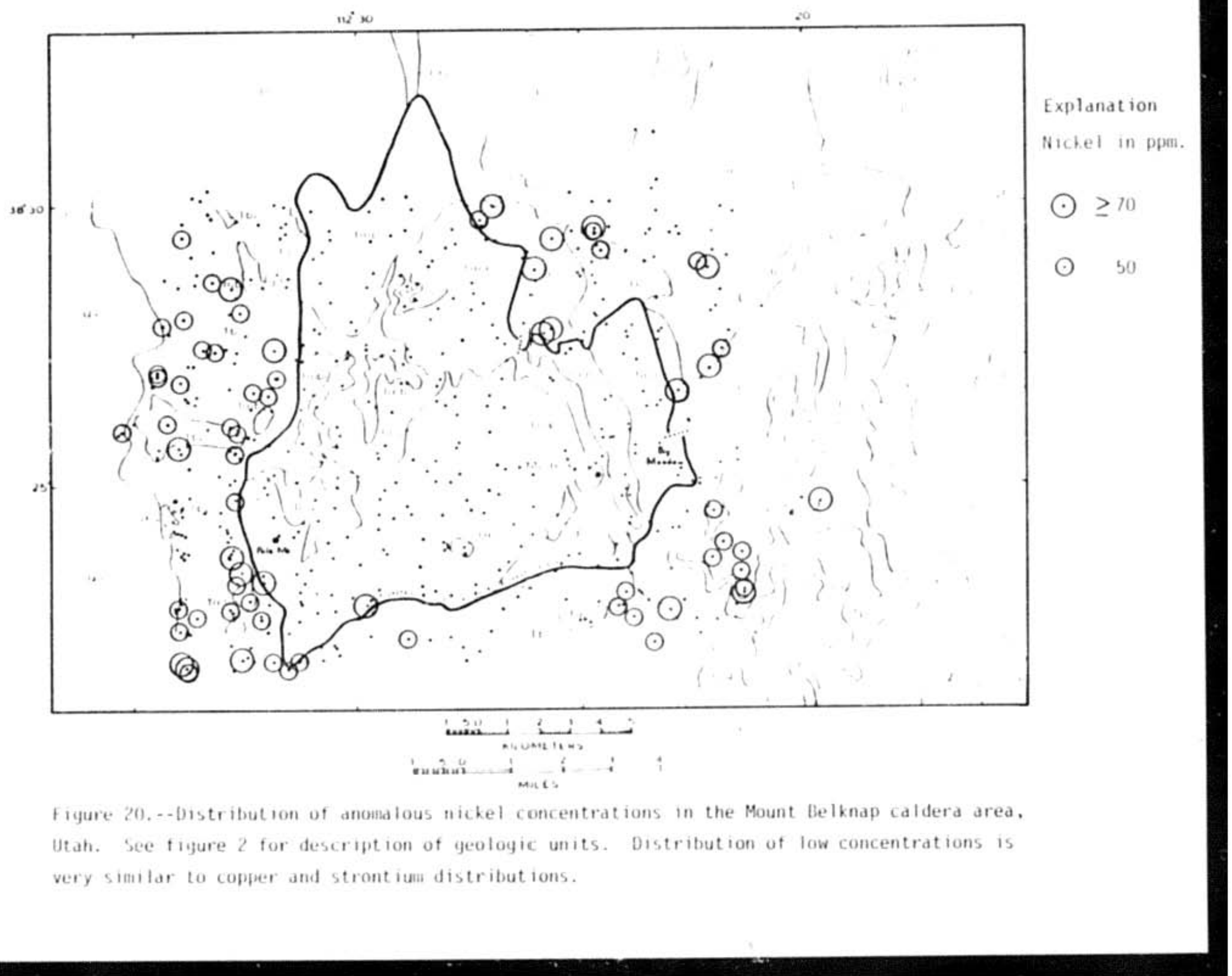




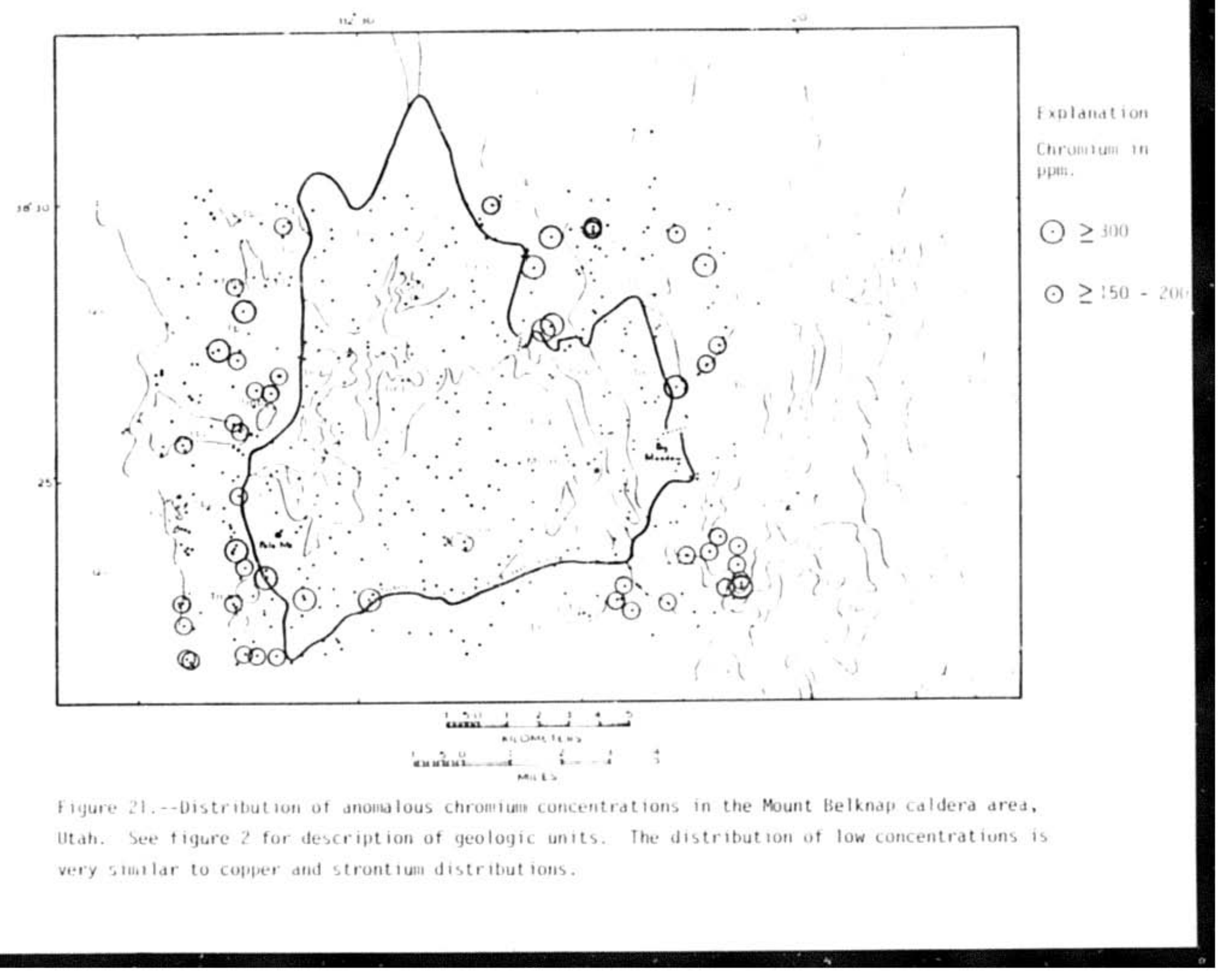




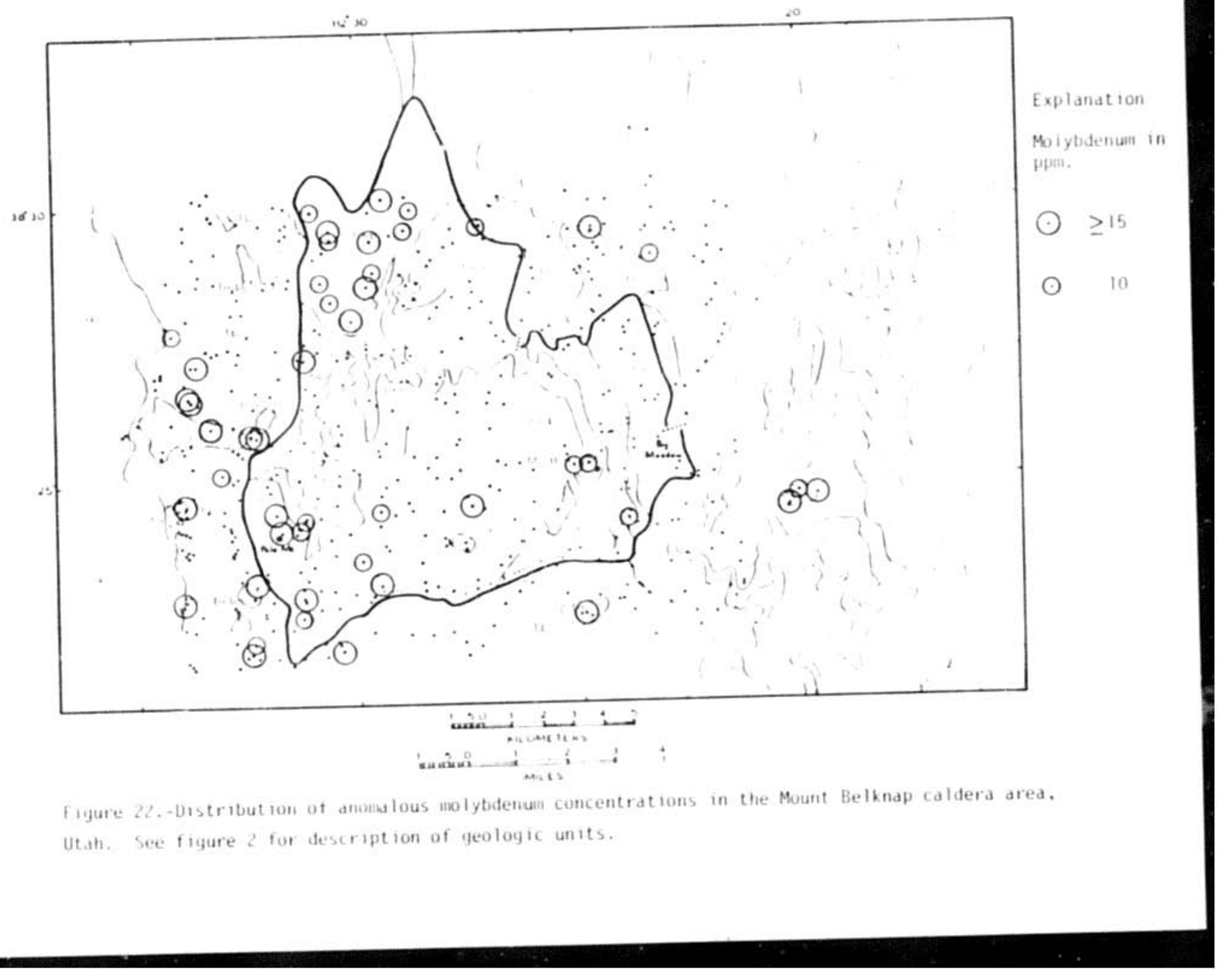




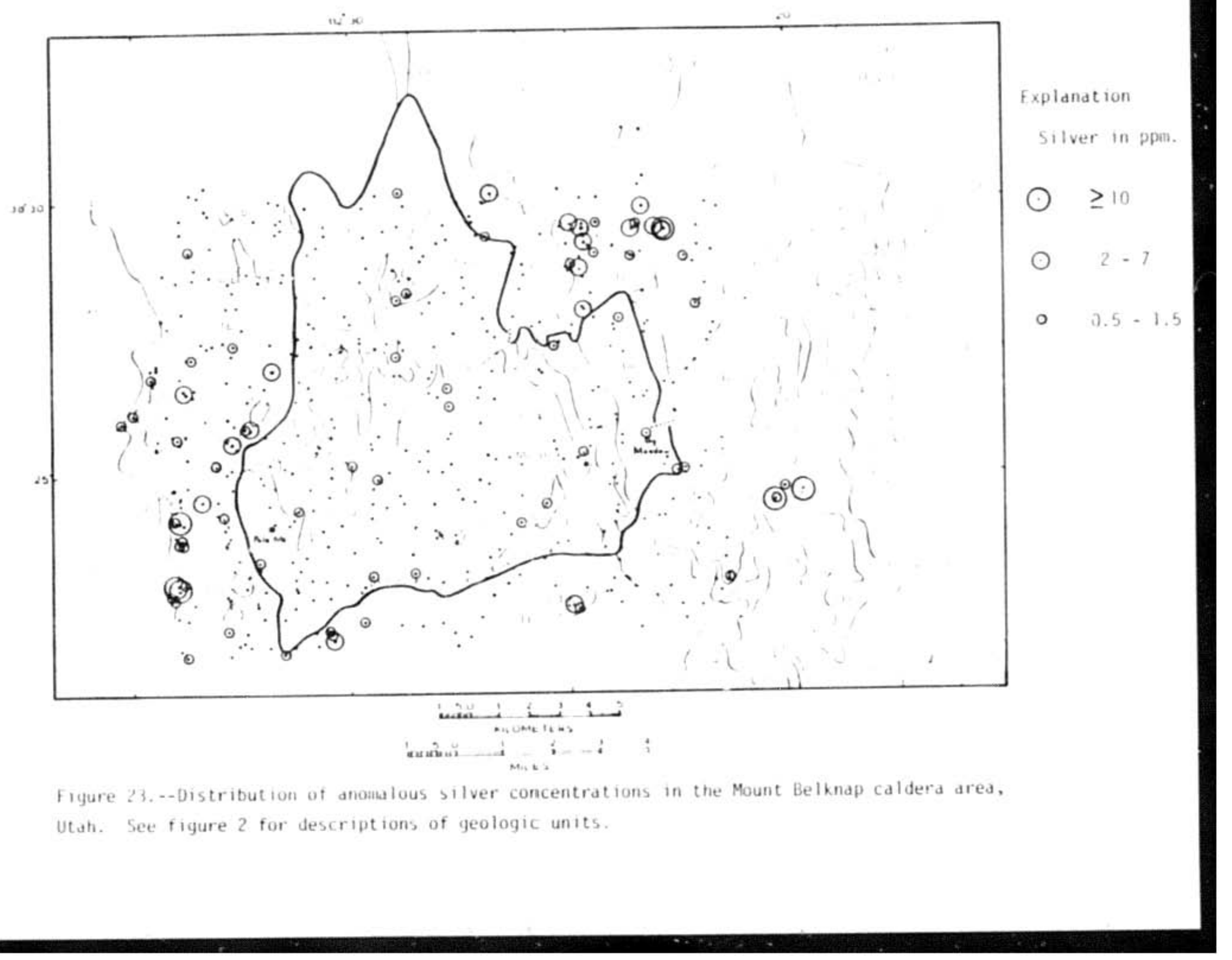




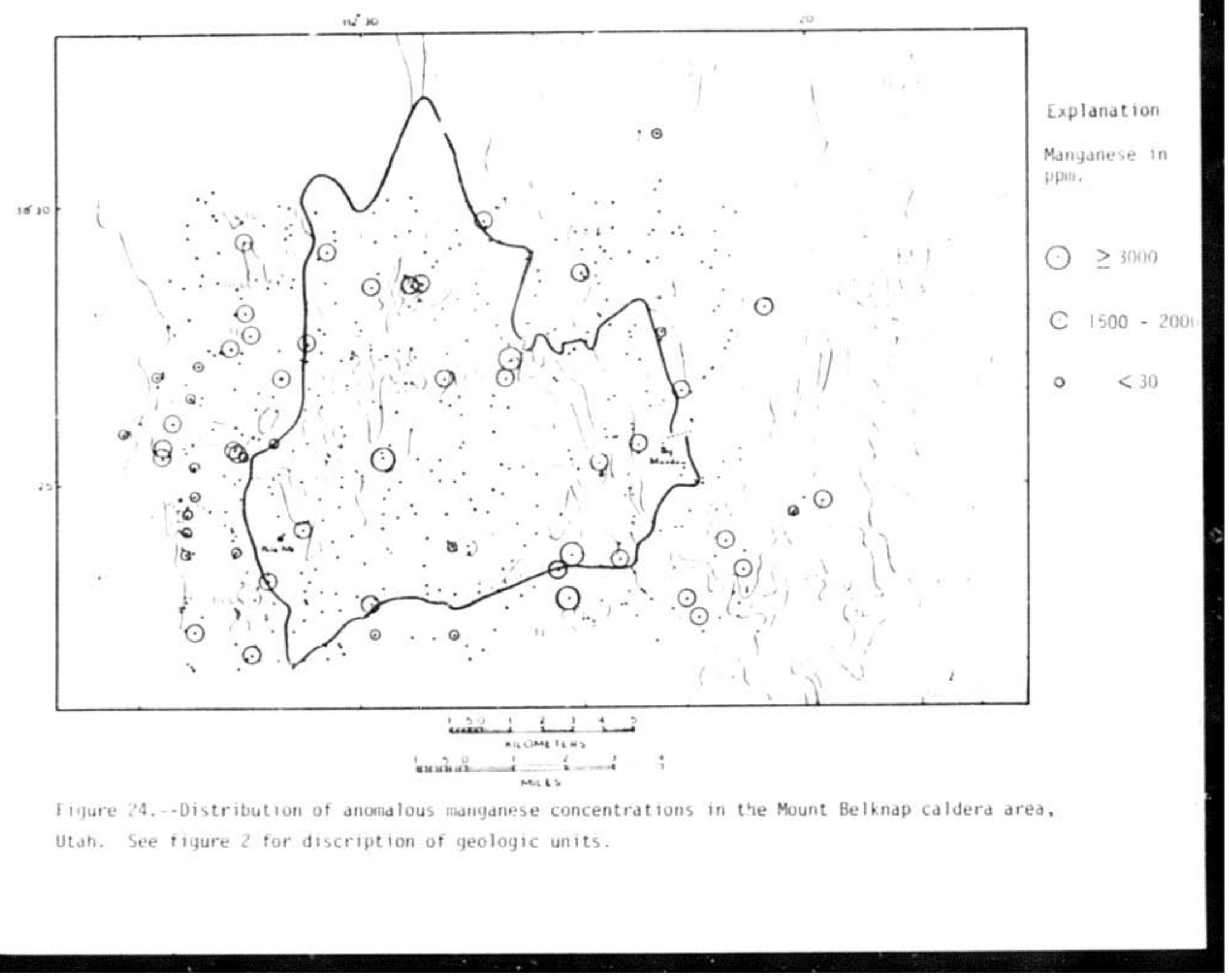




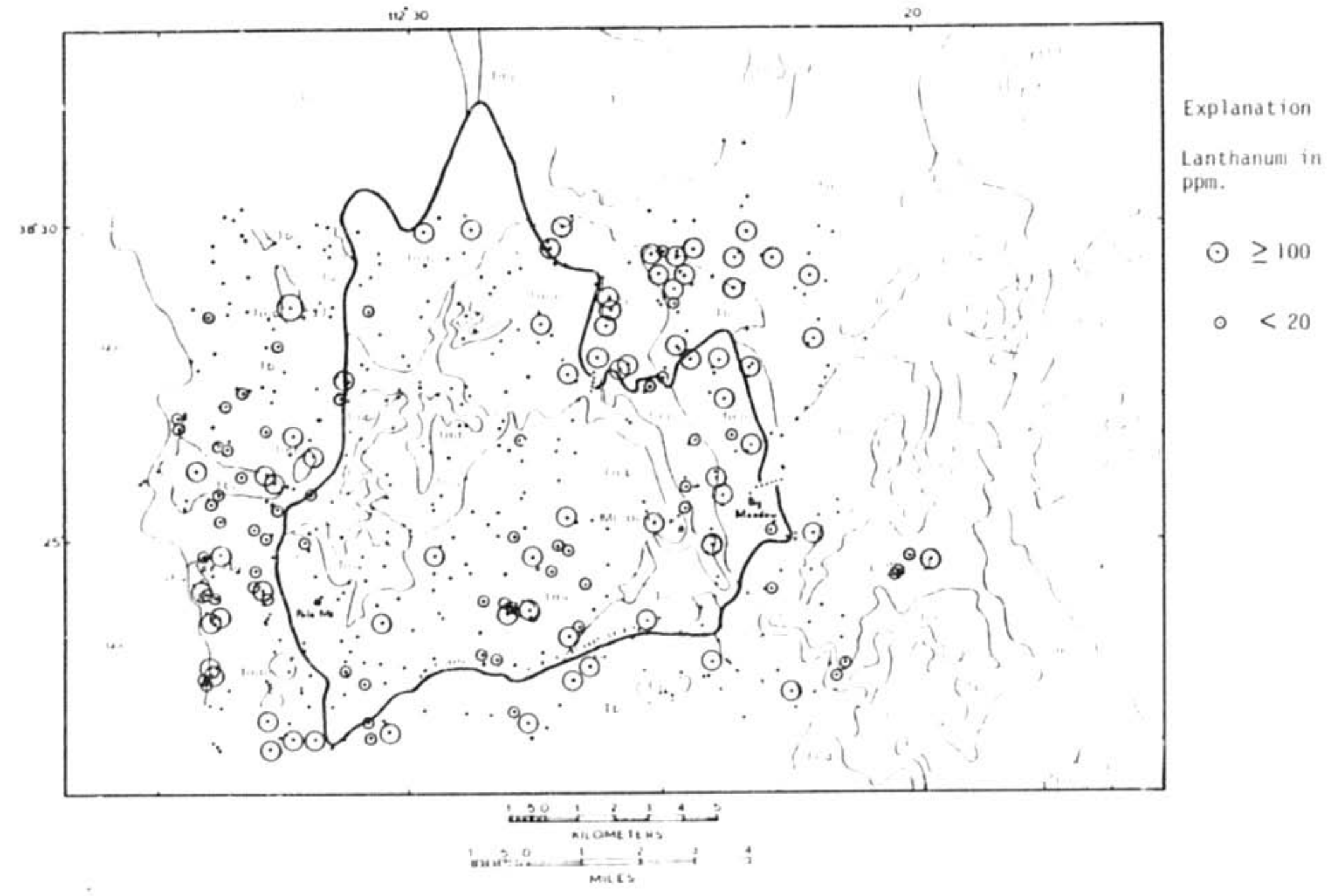

Higure 25.--Distribution of anomalous Ianthanum concentrations in the Mount Belknap caldera area, litah. See figure 2 for description of geologic units. 


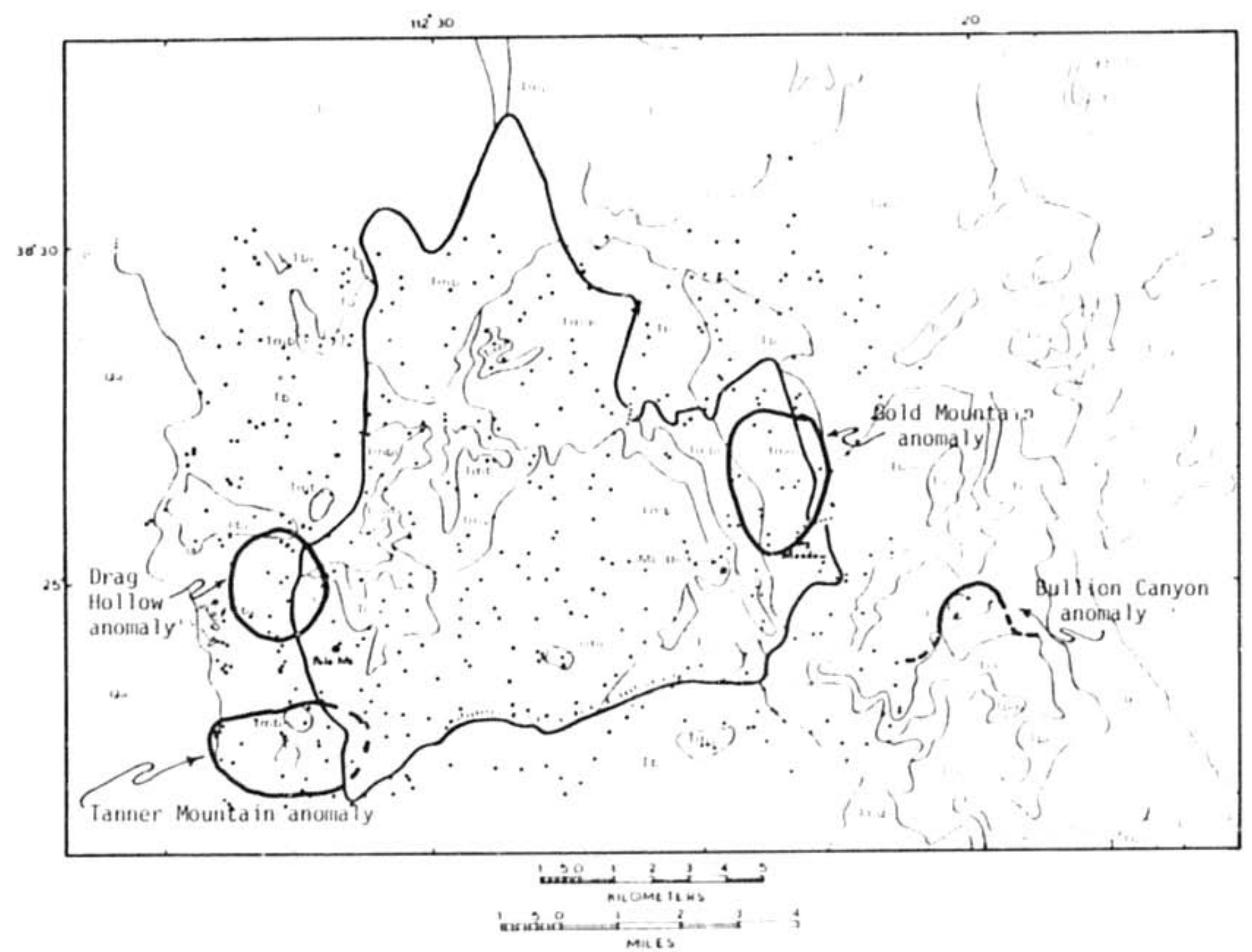

Figure 26.--Aeral distribution of geochemical anomalies described in this report. 
Anotner geochentcal anomaly centered on Gold Mountain in the eastern parof the caldera, is fesignated the Gold Mountatn geochentcal anomaly. 2o and to some degree vo are depleted from myollte samoles $x^{2}: \operatorname{tin}$ this anomaly

(Fiqure 12 and 3 ) and $8 \mathrm{a}, \mathrm{Ca}, \mathrm{Fe}, \mathrm{La}$, and Sr are stitantly enriched. High cancentrations of vo nave seen noted in sandes collected from a breccia oi je and a tailings pile on fiold Yountain (Cunningham and 5teven, :979c). These geochemical trends are opoosite to those described in the Jray Hollow and Tanner Mountain geochentcal anomaltes, which ray reflect dossible factors such as differences in the level of intrusive emplacement, oresent level of eroston, chentcal composition of the host rocks, or in the degree of fracturing and the composition of any clrculating hydrothermal flutds.

Multivariant analysis apdifed to the rock data

The oresent chemical compositiors of the rocks in the study ared oroba: 1 , have resulted from a complex geochentical history, with the ort gind conoosition having been nodified by subsequent hydrothernal act: w:y and other geochemical orocesses. In inis instance, o-mode factor and tysts tecrntues have been used to gain a better understanding of the comolex interrelationsnios that exist in the data. D-moce factor analysis is a qathema:tcal technigue that calculates a groud of end-7enber compost:tions that zooroxt. nately describe the variations witnin the nuttispecte da:a. 3ackaround information on factor analysis can be found in Davis (1973) and klovan and :mbrie (1971). O-mode factor analysts demonstrates :hat certatn ent--enber conpositions or factors exist, but does not attach any sianificance to then. The interoretation of the factors and thet - geological stgntficance is a subjective orocess which relies on the user's knowledge of the geologital and geochemical processes that may have affected the area. infyrmation on the ase and aoplifation of factor analysts to geochemical studtes can be found in 
Table 8. . Factor score matrix

\begin{tabular}{|c|c|c|c|c|}
\hline \multirow[b]{2}{*}{ Constituent } & \multicolumn{3}{|c|}{ Factor } & \multirow[b]{2}{*}{4} \\
\hline & 1 & 2 & 3 & \\
\hline $\mathrm{Fe}$ & 0.190 & -0.277 & 0.209 & -0.256 \\
\hline$M g$ & 0.062 & -0.325 & -0.110 & 0.029 \\
\hline $\mathrm{Ca}$ & 0.008 & -0.346 & -0.154 & $0.1 \leq 5$ \\
\hline$M n$ & 0.228 & -0.171 & 0.059 & -0.136 \\
\hline Ag & 0.068 & 0.012 & 0.224 & -0.197 \\
\hline $\mathrm{Ba}$ & 0.001 & -0.325 & 0.222 & $=0.134$ \\
\hline $\mathrm{Be}$ & 0.382 & 0.039 & 0.124 & -0.304 \\
\hline $\mathrm{Cr}$ & -0.105 & -0.259 & 0.161 & -0.064 \\
\hline Cu & -0.158 & -0.390 & 0.182 & -0.010 \\
\hline La & 0.235 & -0.150 & -0.194 & 0.204 \\
\hline Mo & 0.090 & 0.071 & 0.785 & 0.540 \\
\hline $\mathrm{sb}$ & 0.482 & 0.126 & 0.095 & -0.233 \\
\hline 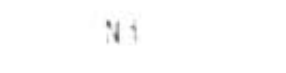 & -0.049 & -0.298 & 0.041 & -0.165 \\
\hline$P b$ & 0.340 & -0.088 & -0.064 & 0.210 \\
\hline Sn & 0.259 & 0.110 & $-0.16 i$ & $0.41 \%$ \\
\hline sr & -0.144 & -0.391 & -0.123 & 0.276 \\
\hline y & 0.315 & -0.134 & -0.101 & 0.008 \\
\hline Ga & 0.349 & -0.141 & -0.155 & 0.187 \\
\hline
\end{tabular}

Underlined scores are significant in factor interoretatior. 


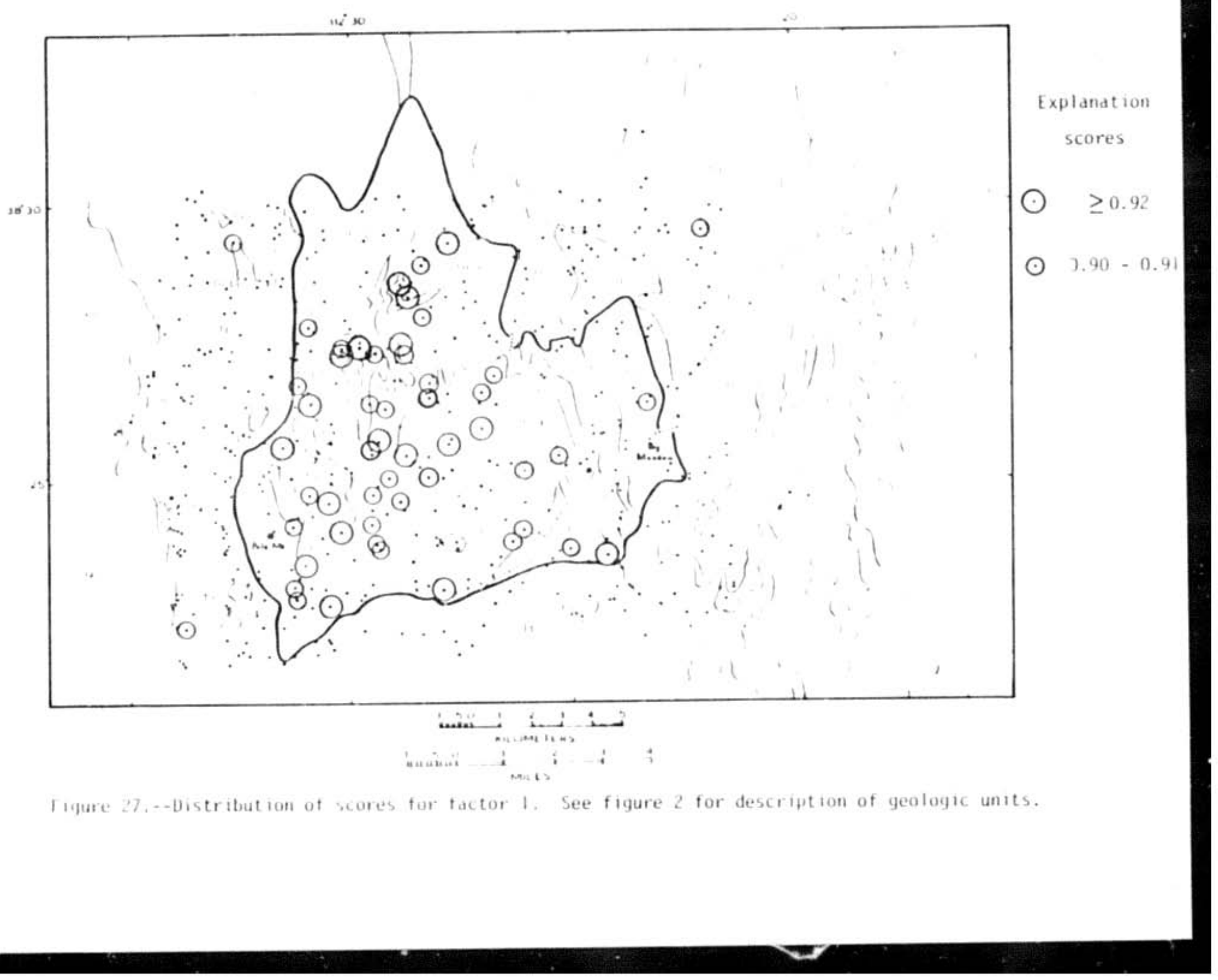




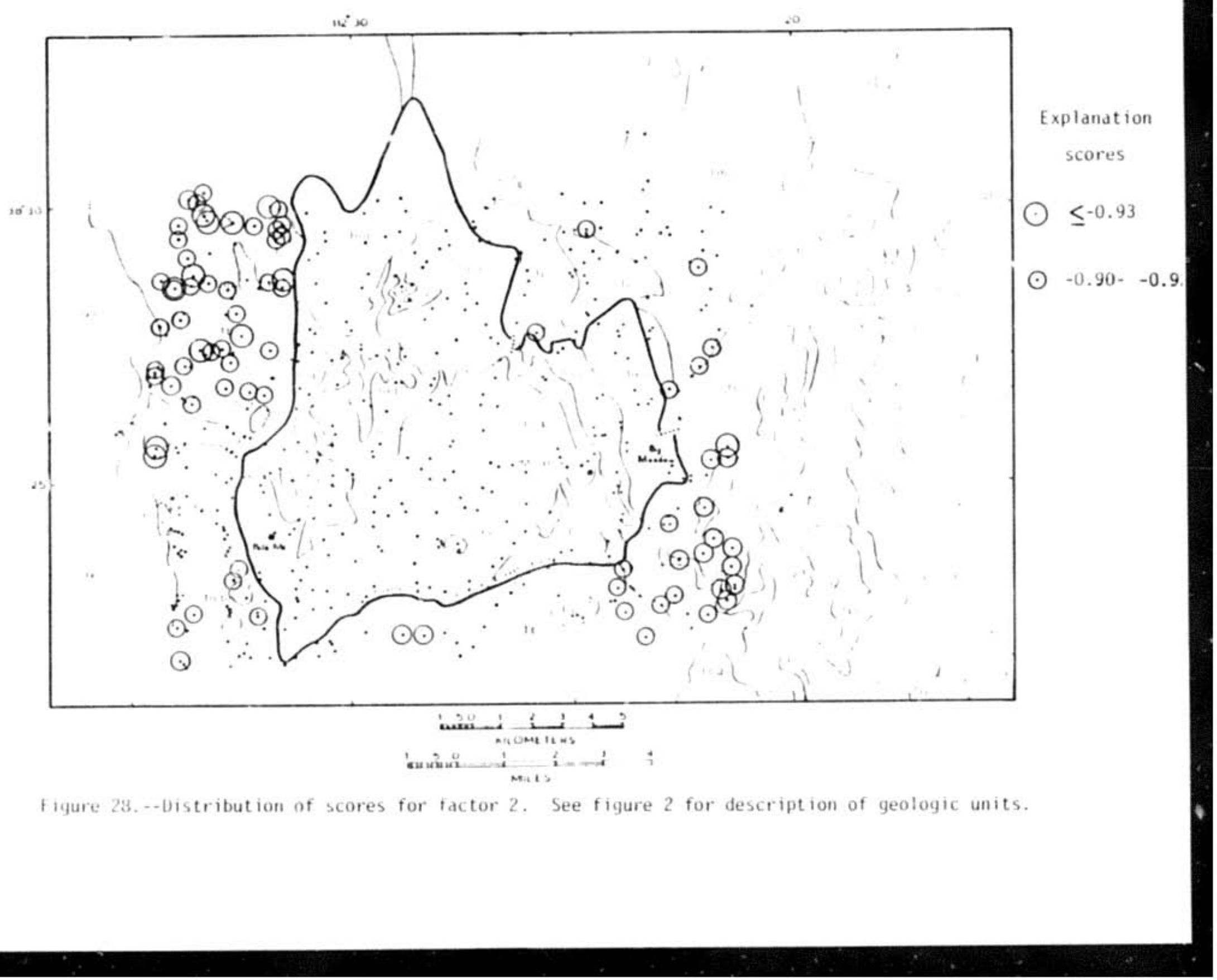





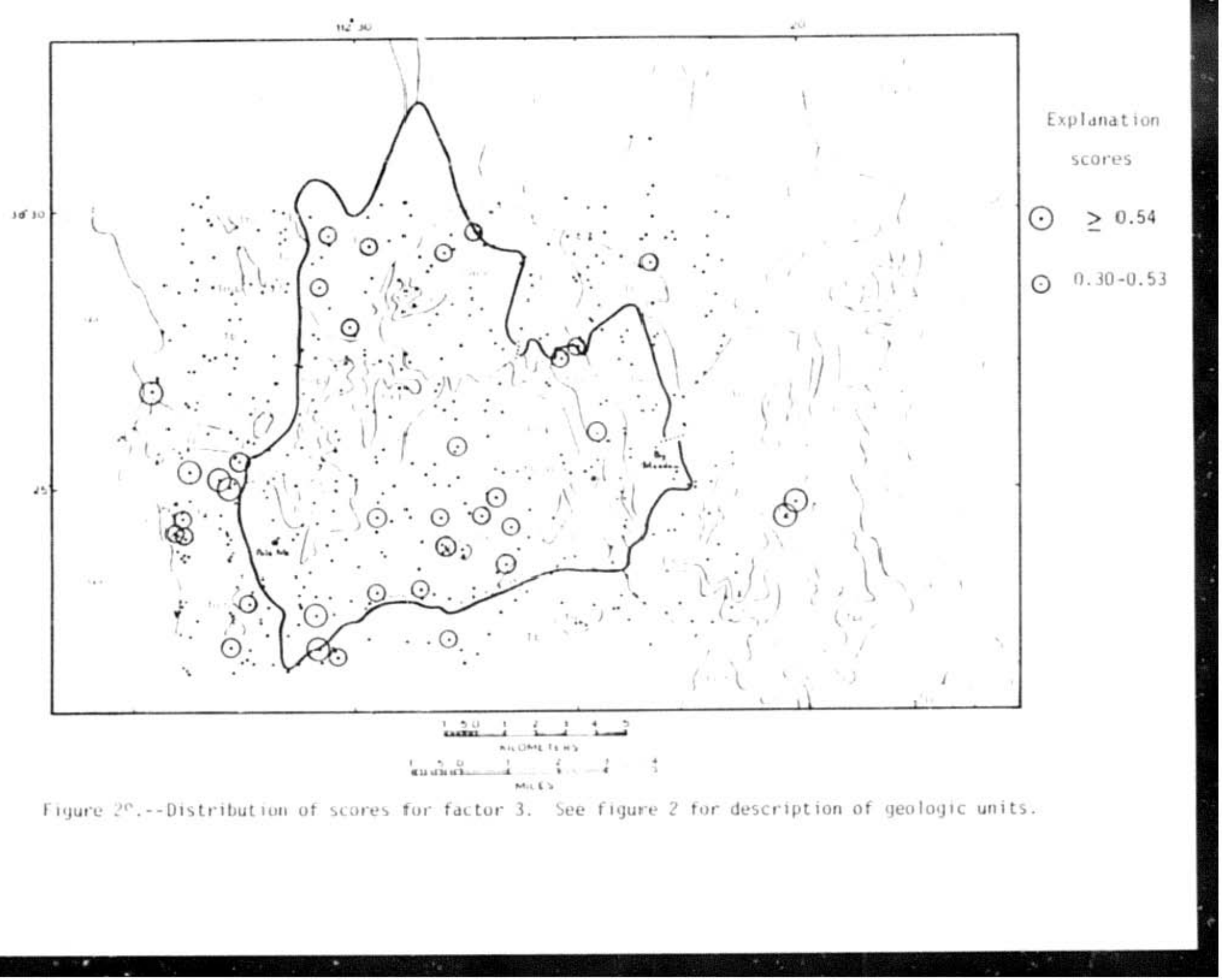





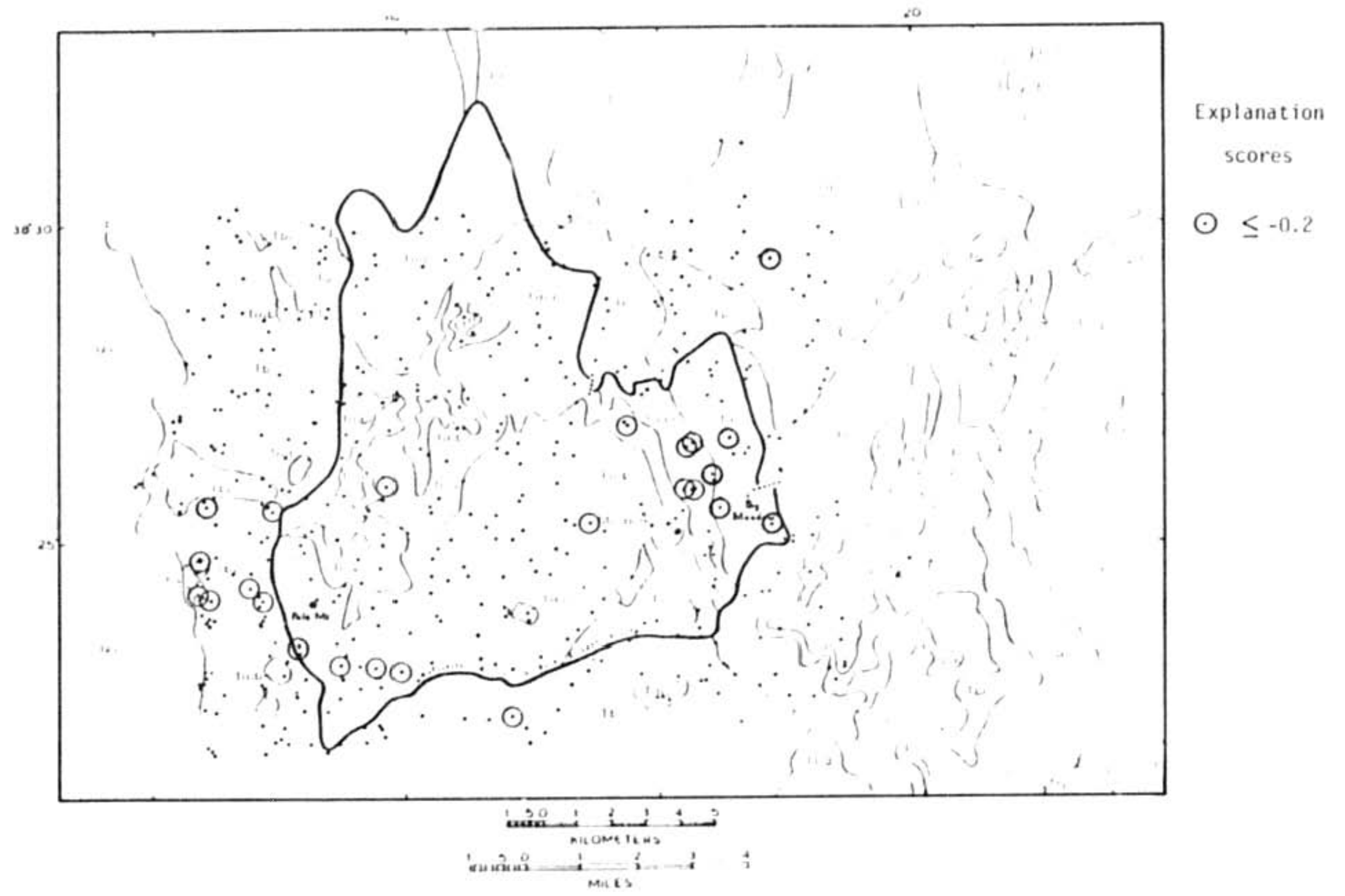

Figure 30.--Distribution of scores for factor 4 . See figure 2 for discription of geologic units. 
this eruptive facies was from a highly-differentiated ragma chamber containing high concentrations of the ore elements.

O-mode factor analysis was able to sebarate, to some degree, the various geochentical contributions :ha* have affected the original chemical composition of the rocks. A four-factor model was used to tterpret the nultielement data. Factors 1 and 2 defined geochemical stil.es interpreted as reoresenting It thologic differences between the rhyolttes and intermediate-composition volcantc rocks. Factor 3 defined a geochemical sutte of elements that can be interoreted as representing nolybdenum nineralization. Factor 3 has a Glustering of high scores within the Drag Hollow, the Tanner Mountath, and the aullion Canyon anomalies. Factor 4 defines a geochemical suite of elements that nay be interpreted to represent an upoer level halo above a dorahyry-tyoe molybdenum sustem. This factor defined the Gold Mountain anomaly and seens :0 complement the elemental suite defined by fact or 3.

A hydrogeochemical survey completed concurrent ly with the rock geochemical survey also indicated the potential for porohyry-tyse molybdenum dedosits in the Mount Belknap calgera vicinity (Tucker and others, 1980). The 319 Meadow hydroceochemical anomaly is located jus: south of the Gold Mountain rock geochemical anomait. The Grassy Creek hydrogeochentical anomaly is located sifant'y north of the Jrag Hollow rock geochemical anomaly. The sitight disclacement of the nycrorgeochenical anomalies with ressect to the rock geochemical aromalies may reflect present structural control of water flow or structural control related to the release of fluids during the emplacenent of a body at deoth.

The qeology and geochenistry of the Mount Belknap caldera and vicinity suggest that highly differentiated leucocratic magmas vere int ruded and(or) erupted in and around the caldera. The Oraq Hollow, Tanner Mountatn, Gold
Mountain, and Bullion Canyon geochemical anomalies exhibit many of the characteristics associated with the emplacenent of highiy-differentiated residual fluids from these magmas, which may have deposited economis concentrations of Mo. These anomalous areas reoresent zotential tarqets for future porphyry-type nolybdenum mineral exploration.

$$
\text { References cited }
$$

Cunningnam, C. G., and Steven, T. A., :978a, Geologic map of the Delano deak Wh quadrangle, west-central Utah: U.S. Geological Survey Miscellaneous Field Studies Mad MF-967, scale $1: 24,000$.

1973b, Postulated rodel of urantum occurrence in the centrat tinitig area, Marysuale Distertct, west-central 'Jtan: J.S. Geological Survey Open-File Zedort 73-1093, 19 o.

1979a, Geologic mad of the Delano Deak VE quadranqle, west-central

Jtan: I.S. Geological Survey Miscellaneous fteld Studies Mad MF-:La5, scaie $1: 24,000$.

1979b, Geologic map of the Deer Tratl Mountaln-Alunite Ridge xinting ared, west-central Utan: U.S. Geological Survey Miscellaneous feologit: investigations Yao :-1230, scale $1: 24,000$

1979c, Envitronments favorable for the occurrence of uranium withtn the Mount Belknap caldera, Beaver Valley and Sevier atver Zalley, westcentral Utah: U.S. Geological Survey Open-file Report 79-434, 15 D. 1979d, Mount Belknap and Red Hills calderas, and associated rocks,

Marysuale volcanic field, west-central Utah: U.S. Geological Survey Bulletin 1468,34 D.

1979e, Uranium in the central mining area, Marysvale District, westcentral Utah: U.S. Geological Survey Miscellaneous Geologite

investigations Mad: $:-1: 177$, scale $1: 24,000$ 
Cunningham, C. Fi., and Steven, T. A., 1980 , Seologic nad of the Beaver VE quadrangle, 'tean: Y.S. Geological Survey Miscellaneous Field Studies Map MF-1:91, scale $1: 24,000$

Daqger, G. A., 1972, Genes is of the Mount Desant tungston-molyodenum-bi smuth deposit, Vew Brunswick, Canada: Transactions of the institution of

Mining and Metallurgy, v. 323, D. B73-3:02.

Davis, J. C.. :973. Statistics and data analysis in qeology: Vew rork, John Wiley and Son, : nc. $550 \mathrm{o}$.

Fleck, 2. J., Anderson, J. J., and Rowley, D. D., 1975, Chronologv of nid-ertiary volcanisa in High plateaus region of ttah, in Cenozorc geology of southwestern High Plateaus of Utan: Geological Society of tinerica Soeciat Daper $150,0.53-62$.

Groves, J. .., and Mccareny, -. S., 1973, Fractiond crysiditization and the origin of tin gevosits in zranitolits 4ineral. Jeposita, r. :3, 2. 11-25 Groves, D. :., and Taylor, R. G., 1973, Gretsentzat:on and nineratization d: Anchor tin mine, northeas: Tasmania: "ransactions of the :-nstitution of Mining and Metallurgy, v. 323, o. 135-1:6.

Hoffnan, J. J., Brew, D. A., Forn, C. L., and Jonnson, 3. 3., :979, Chemt ca variabillty of a metavolcanic rock jnit in the Tracy Arm-fords Ferror Aliderness study area, Alaska, and the deftnition of background va'ues for geochemical ourooses, in Shorter Cont ributions to Geochenistry

1979, Y.S. Geological Survey Professtonal paper 1:29A-A-:, D. J!-E9. Hosking, K. F. G., 1965, The search for :in: Mining Magaztne, v. 113, D. $368-382$. klovan, J. E., and imbrie, J., :971, An algorithm and For: ran-:": program for large-scale 0-mode factor andivsts and calculation of actor scores: Sournal of the international issociation of Mathenatical Geolocy, v. 3. no. $1,0,51-77$.

Mcilatr. A. H., 1951, Paleozolc stratigradohy of northwestern Arizona: Anertcar Association of Detroleum Geologists Bulletin, V. 35, no. 3, D. 525-526 Miller, d. 2., vctuch, J. B., and Ficklin, A. 4., 1979, 2osstole urantur mineraltzation, Mineral Mountains, Utah: U.S. Geological Survey DaenFite ?eoort 79-:354, 44 D.

1990, Dossiole uranium mineralization, Beaver Basin, Itan: J.5.

Geologica! Surzey Den-ftle Redort 30-508, 35 o.

Motooka, J. Y.. And Grines, D. J., 1975, Ana'ytical prectston of one-5ix:h order sentiquantitative soectrographic andiysis: 1.5. Geological Survey

Circular 738, 250.

Shars, J. E., 1978, A nolyodenum tineraltzed breccla pipe complex, Redwell.

Colorado: Economic Geology, .. 73, o. 369-382.

Sheraton, J. A., and Black, L. P., :973, Geochemistry of mineralized grantile

rocks of northeast Jueensland: Journat of Geochemtcal Expiorstion, v. 2, D. $331 .-343$

Sillitoe, R. H., Halls, C., and Grant, J. V., 1975, Porphyry tin deposits in Bolivid: Economic Geolocy, v. 70, D. 913-917.

Snedecor, G. X., and Cockran, A. G., 1967, Statistical Methods: lowa State University Press, Ames $6 \mathrm{th}$ edt:., $593 \mathrm{D}$.

Steven, T. A., 1977, Geologic map of the Sevier Sid quadrangle, west-central

Utah: U.S. Geological Survey Miscellaneous field Studies Mad MF-962, scale $1: 24,000$. 
Steven, .. A., and Cunningham, C. G., 1979, Uranium potential of the 319 John caldera, Beaver County, Itan: U.S. Geological Survey Dpen-File Report จ-527, 160.

1980, Geologic map of the Sevier SE quadrangle, west-cent ral Itan:

4.5. Geological Survey Miscellaneous field Studies Mad Mf-1109,

scale $1: 24,000$.

Steven, T. A., Cunningham, C. G., and Machette, 1980, interqrated urantum sustems in the Marysuale volcanic field, west-central utah: IJ.S. Geoloatcal Survey Open-fite Report 30-524, 39 o.

Steven, .. A., Cunntngham, C. G., Vaeser, C. ..., and Yehnert, H. H., 1979 , Revised stratigraphy and radiometric aqes of volcanic rocks and inthera teposits in the Marvsvale area, west-central utah: J.S. Geological Survey Bulletin $: 269$, :0 5.

Steven, . A., Cunningham, C. G., and Rowley, D. D., :373, Geology and mineralization in the Marysuale aining ared, vest-central utan. in Guidebook : mineral deposits of southwes:ern tah: tan Geological As soctation Puditication ?, 0.67-70.

Fischendorf, G., 1972, The netallogenetic basis of tin exploration th the Erzgeotrge: Fransactions of the institution of Mining and Metalluray, ". 328, D. $9-24$.

Tucker, J. O., Miller, '., R., Motooka, J. Y., and Hubert, A. E., 1981, A rock and stream sediment concentrate survey over a known Mo-Sn anomaly in the southern wah wan Mountains, Itan: U.S. Geological Survey Open-file Report $81-576,70 \mathrm{p}$.

Tucker, R. E., Miller, H. R., and McHugh, J. 3., :980, Geochemical resul:s from a natural waters study in the Mount Belknap caldera and victnity, It an: Y.S. Geological Survey Oper-fitle Reoor 30-:05!, 53 o.
- uker, 2. E., 1981, 2 rock and hydrogeochenical survey of the Mount Belknap caldera area, utan: Masters thests, Coloraco School of Mines (in oress). Van Alstine, P. E., 1976, Continental ritts and tineaments associated with

7ajor fluorsdar districts: Economiz Geology, v. 71, o. 977-987.

vallace, S. R., Mackenzie, 4. B., Blatr, 2. G., and Muncaster, v. K., 1973, Geology of the llad and Henderson volyodenite deposits, Clear Groek County, Colorado, with a section on a compartson of these dedosits with

shose at clinax, Colorado: Economic Geology, v. 73, 0. 325-368. 
Appendix 1.-- Rock andissis tron the Rount getknap caldeta viginity

Explanation; aap units are listes next to samb nuators; concentrationa are the detection liaits.

\begin{tabular}{|c|c|c|c|c|c|c|c|c|c|c|c|c|c|}
\hline \multicolumn{2}{|c|}{ sanole } & \multicolumn{2}{|c|}{ Lstifude } & \multicolumn{3}{|c|}{ Longlive } & \multirow{2}{*}{$\begin{array}{r}\text { ie } .052 \\
5.00\end{array}$} & \multirow{2}{*}{$\begin{array}{c}\mathrm{Mg} .022 \\
2.00\end{array}$} & \multirow{2}{*}{$\begin{array}{r}\text { co. } .058 \\
2.00\end{array}$} & \multirow{2}{*}{$\begin{array}{c}11.0022 \\
1.000\end{array}$} & \multirow{2}{*}{$\begin{array}{c}\text { No 10pps } \\
700\end{array}$} & \multirow{2}{*}{$\begin{array}{c}\text { Ag. SDDA } \\
<.5\end{array}$} & \multirow{2}{*}{$\begin{array}{l}\text { 8. 200DA } \\
2,000\end{array}$} \\
\hline 001 & 10 & 38 & 2035 & 112 & 31 & 30 & & & & & & & \\
\hline 002 & $i t$ & 38 & $20 \div 9$ & 112 & 32 & 18 & 5.00 & 5.00 & 5.00 & 1.000 & 700 & <. 5 & 2.000 \\
\hline $00 s$ & $1=b$ & 38 & 250 & 112 & $\$ 2$ & 3 & .20 & $<.02$ & .10 & 1.000 & 15 & $N$ & $1,5 \mathrm{co}$ \\
\hline ans & $t=01$ & 93 & 2562 & 112 & 31 & 8 & 2.00 & .10 & .10 & .500 & 700 & N & 620 \\
\hline 000 & $\ln n$ & 98 & 2560 & 112 & 50 & 23 & 1.00 & .20 & .10 & .200 & 700 & N & 70 \\
\hline 007 & $1=01$ & 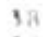 & $256 ?$ & 112 & 31 & 8 & 1.00 & 10 & .10 & .100 & 1,000 & $N$ & $<20$ \\
\hline $00 \mathrm{~s}$ & tntet & 38 & 2530 & 112 & 3: & so & 1.00 & .20 & .50 & .200 & 500 & $<. s$ & $*$ \\
\hline 010 & 10 & so & 2536 & 112 & 32 & 30 & $\$ .00$ & 5.00 & 3.00 & .500 & 2.000 & $N$ & 1,200 \\
\hline 011 & $\operatorname{lnb}$ & 38 & $2 \div 28$ & 112 & 32 & 36 & .20 & $<.02$ & c.0s & 1.000 & 30 & $\mathrm{~N}$ & soc \\
\hline $0: 2$ & it & 38 & 256 & 112 & 32 & 62 & 2.00 & .30 & .20 & .500 & 200 & $<.5$ & 1.000 \\
\hline 013 & to & 16 & 2630 & $1: 2$ & 32 & 69 & . so & 6.02 & $\therefore .0 s$ & 1.000 & so & 4.5 & 200 \\
\hline 014 & 10 & 38 & 259 & 112 & is & 3 & 1.00 & .02 & $\therefore .0 s$ & 1.000 & 150 & 1.5 & 100 \\
\hline 016 & 10 & 38 & 264 & 112 & 32 & 67 & .50 & 6.02 & s.ns & 1.000 & 50 & $\mathrm{~N}$ & 203 \\
\hline 017 & it & 36 & $23<3$ & 112 & 32 & 69 & 2.00 & 1.00 & 2.00 & .500 & 700 & N & 1,000 \\
\hline 018 & it & 30 & 2366 & 112 & 32 & 30 & 2.00 & 1.00 & 2.00 & .500 & 500 & N & 500 \\
\hline 010 & $1 \mathrm{t}$ & 18 & 2125 & 112 & 32 & 33 & 10.00 & 5.00 & 5.00 & 1.000 & 700 & N & 1.000 \\
\hline 020 & $I=b$ & 18 & 2325 & 112 & 32 & 6 & .50 & .02 & .10 & .260 & 150 & .5 & 100 \\
\hline 021 & tot & 38 & 2317 & 112 & 31 & so & 10.60 & 2.00 & 5.00 & 1.000 & 1.500 & N & 1.500 \\
\hline $02 ?$ & 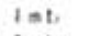 & 98 & $22<0$ & 112 & 31 & 10 & .50 & .10 & 1.00 & .100 & 300 & <.s & $<20$ \\
\hline 025 & $\ln b$ & 15 & 2265 & 112 & 30 & 32 & 1.00 & .02 & $s .05$ & .020 & iso & 4.5 & 200 \\
\hline 026 & $1>0$ & 14 & 2268 & 112 & 30 & 25 & 1.00 & .05 & .10 & $.0>0$ & 500 & 6.5 & 70 \\
\hline 025 & 1 at & 38 & 231 & 112 & $3: 2$ & 6 & .50 & .015 & .05 & .100 & 150 & 4.5 & so \\
\hline $0 \geq 0$ & 10. & en & 231 & 112 & 29 & 62 & $1 . \mathrm{co}$ & .05 & .05 & .200 & 200 & $n$ & so \\
\hline 027 & it & la & 2236 & 112 & 20 & 67 & 5.00 & 5.00 & 3.00 & 1.000 & 1.500 & N & 1.500 \\
\hline $0.2 \mathrm{~s}$ & $t=t$ & 50 & 2310 & 112 & 20 & 22 & 1.00 & .05 & .05 & .200 & 500 & .5 & so \\
\hline $0<2$ & $\operatorname{lat}$ & is & 235 & 112 & 30 & 20 & 1.00 & .20 & .20 & .100 & 200 & C.s & 70 \\
\hline 031 & Int. & 38 & 2357 & 112 & 30 & 37 & 1.00 & $.0 \mathrm{~s}$ & .05 & .200 & 700 & $n$ & so \\
\hline 012 & $1=0$ & 38 & 2360 & 112 & 30 & 20 & .50 & .20 & .20 & .200 & 200 & $<.5$ & 150 \\
\hline $03 s$ & $\ln b$ & 38 & 260 & 112 & 30 & ? & 1.00 & .10 & .10 & .200 & 500 & $N$ & so \\
\hline 036 & $t \in b$ & 38 & 2910 & 112 & 29 & 56 & 1.00 & .10 & 2.00 & .100 & 1.000 & N & 50 \\
\hline oss & $1 a b$ & 96 & 250 & $1 \cdot 2$ & 28 & 63 & 1.00 & .20 & .10 & .100 & 500 & $<.5$ & so \\
\hline 090 & $t=t$ & 98 & 2513 & 112 & 28 & 20 & 1.00 & .20 & .50 & .200 & soo & $<.5$ & 30 \\
\hline 037 & $t=b$ & 98 & $? 610$ & 112 & 30 & 29 & 1.00 & .20 & .10 & .500 & 1.000 & $<.5$ & 50 \\
\hline 038 & tan & 98 & 2650 & 112 & 30 & 23 & 1.00 &.$\$ 0$ & .30 & .300 & 1.000 & $N$ & 100 \\
\hline 050 & $t=v$ & 38 & 2531 & 112 & 29 & 32 & 1.00 & .20 & .10 & .050 & 5,000 & $N$ & 100 \\
\hline 060 & $i \in b$ & 36 & 2560 & 112 & $2 \%$ & 20 & 1.00 & .10 & .05 & .200 & 700 & $N$ & so \\
\hline 063 & lab & 38 & 2961 & 112 & 29 & 21 & 1.00 & .10 & .10 & .200 & 1.000 & $N$ & 70 \\
\hline 062 & $\tan x$ & 38 & 2535 & 112 & 24 & is & 1.00 & .20 & .20 & .100 & 1,000 & <. 5 & 70 \\
\hline 063 & It & 35 & 2536 & 112 & 32 & 40 & 10.00 & 5.00 & 5.00 & 1.000 & 100 & $n$ & 1.500 \\
\hline 0.6 & $|n t|$ & 18 & 27 is & 112 & 30 & 11 & 1.00 & .10 & .10 & .100 & 300 & $<.5$ & 20 \\
\hline 0,5 & 1041 & 38 & 211 & 112 & 30 & 20 & 1.00 & .10 & 1.00 & .100 & 700 & $\mathrm{~s}$ & 620 \\
\hline 060 & $1=0$ & ie & $28<A$ & 112 & 90 & 21 & 1.00 & .50 & .30 & .200 & 300 & c.s & 70 \\
\hline 067 & glo & 18 & $20 \quad 30$ & 1,2 & 30 & 50 & 1.00 & .10 & 2.00 & .050 & 1.000 & N & 620 \\
\hline $0, A$ & $1=01$ & it & 20.1 & 112 & 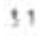 & 10 & 1.00 & .20 & .05 & .200 & 500 & $n$ & 620 \\
\hline 0,8 & 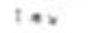 & 18 & 2021 & 112 & is & 11 & 1.50 & .20 & .05 & .200 & 1.000 & $\checkmark$ & 620 \\
\hline
\end{tabular}




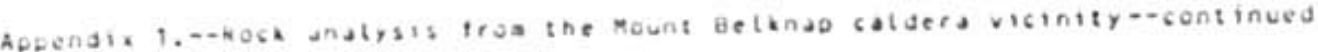

Sathe

00, is

002 is

ons 1 a

coo ian

Oof tac:

$00 . \quad 1=b$

01014

$011 \quad 1=b$

013 it

016 to

210 10

aro is

$01 \%$ to

$0201=6$

021 tat

1)? Tat

क)

$024 \mathrm{int}$

023 1

D2s 1a:

027 it

$023 \quad t=0$

$0: 9 \quad$ ist

c3r tas

032102

031 ist

036 tat

$055 \quad t=0$

095 tot

031 int

$03 k$ tan

og to.

$060 \quad 1 \mathrm{~mL}$

$061 \quad t=0$

062 inv

063 to

Int.

0,5 ind

063 ins

a, a 40

6? co SDOA

$\cos 2000=$

cu Sopa

30.00
5.00
5
20.00

5.00

30.00

20.00

.00

$\stackrel{N}{N}$

20.00

30.00

15.00

10.

$\frac{N}{20.00}$

50.00

30.00

$n$

$n$
$n$
$n$
$n$

30.00

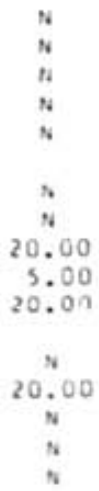

200
150
30
$N$
$N$
5
$N$
50
$<20$
100
420
30
20
620
620

200

200
500

so

$<20$

$<20$
$<20$
300

$\times 20$

620
$N$
620
620
$N$

$<20$

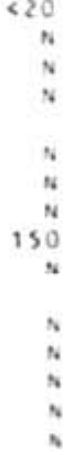

10.0

15.0

15.0

15.0

10.0

10.0

10.0

3.0
13.0

15.0

20.0

20.0

15.0
LA 20DD

no spoa

No $20 \mathrm{ppm}$

$\times n$
620
30
70
50

so

70
70
420

$<20$
20
30

$<20$
$<20$

28

30

420

30

420
30
30

70
50
70
20
70

70
50
70
70
50
N1 SDD =

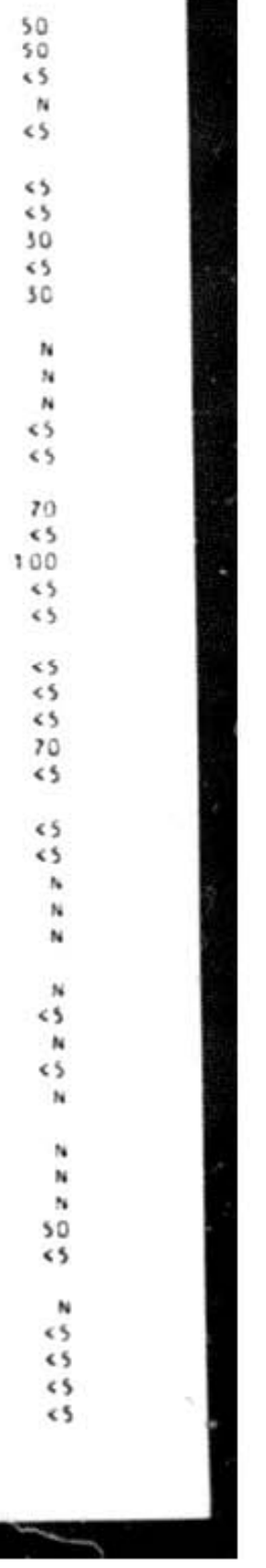




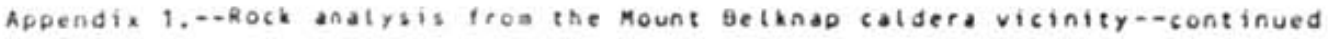

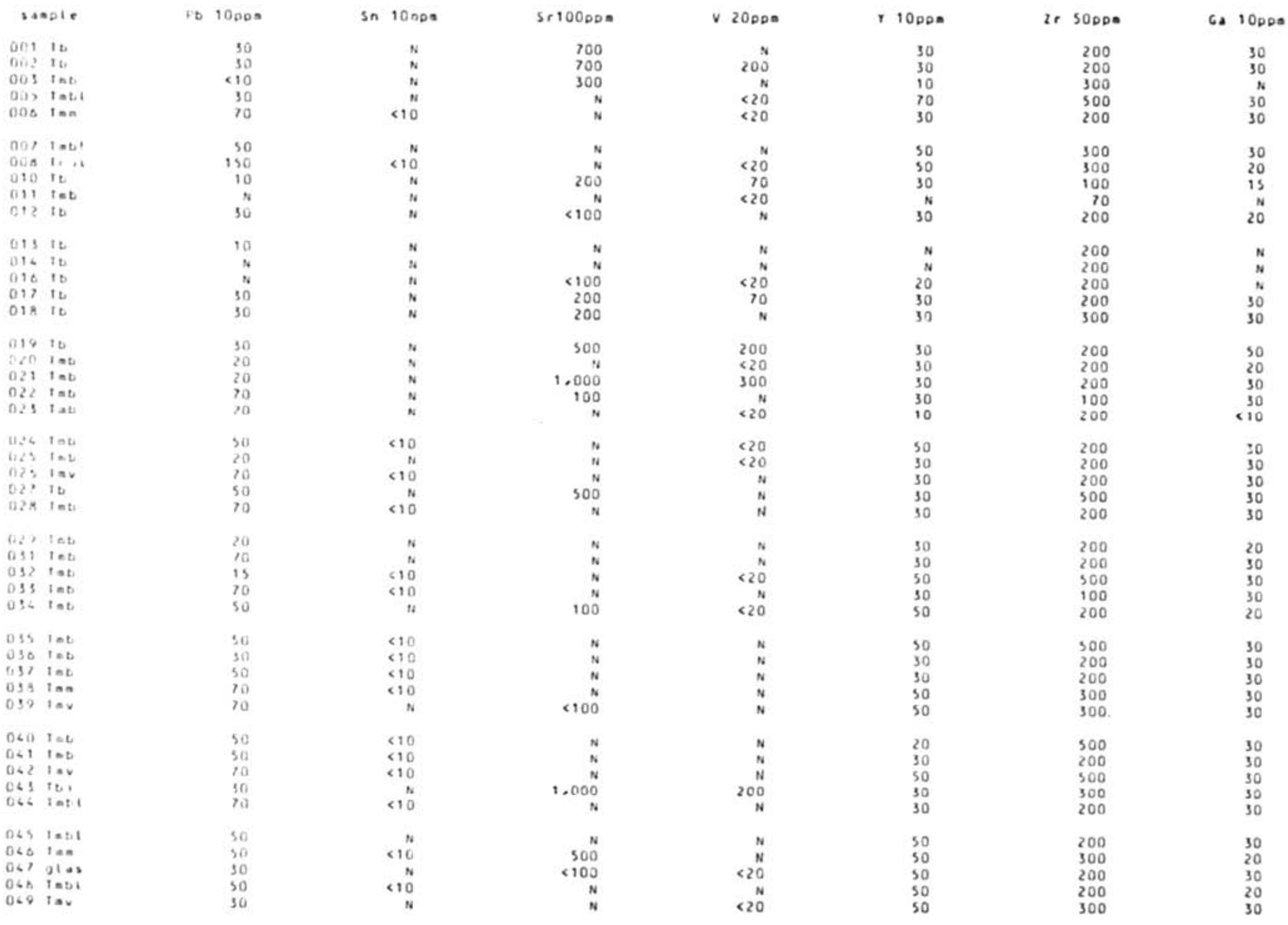




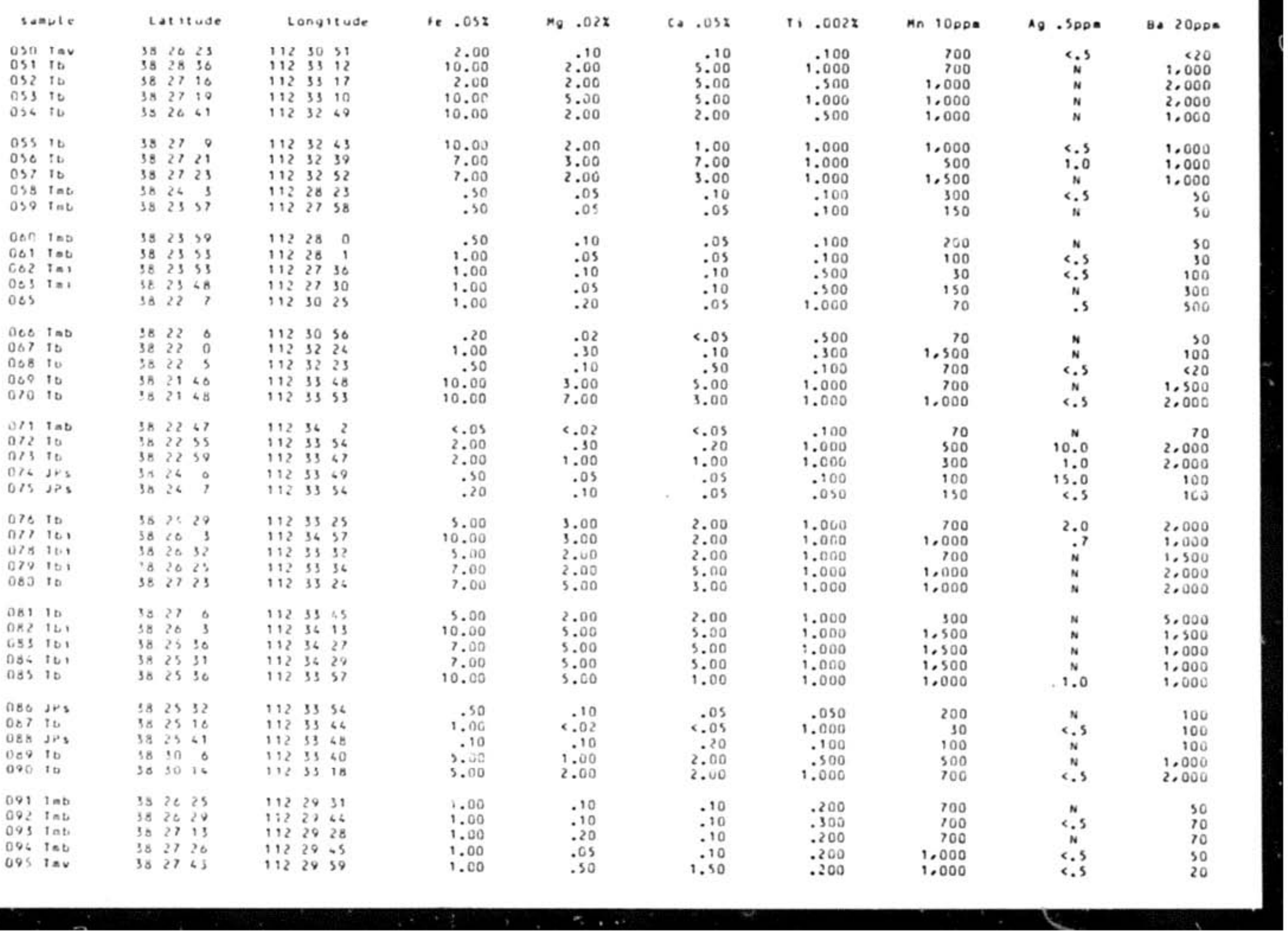


Appendix 1.e-Rock analysis fros the Mount belknap caldera vicinityacontinued

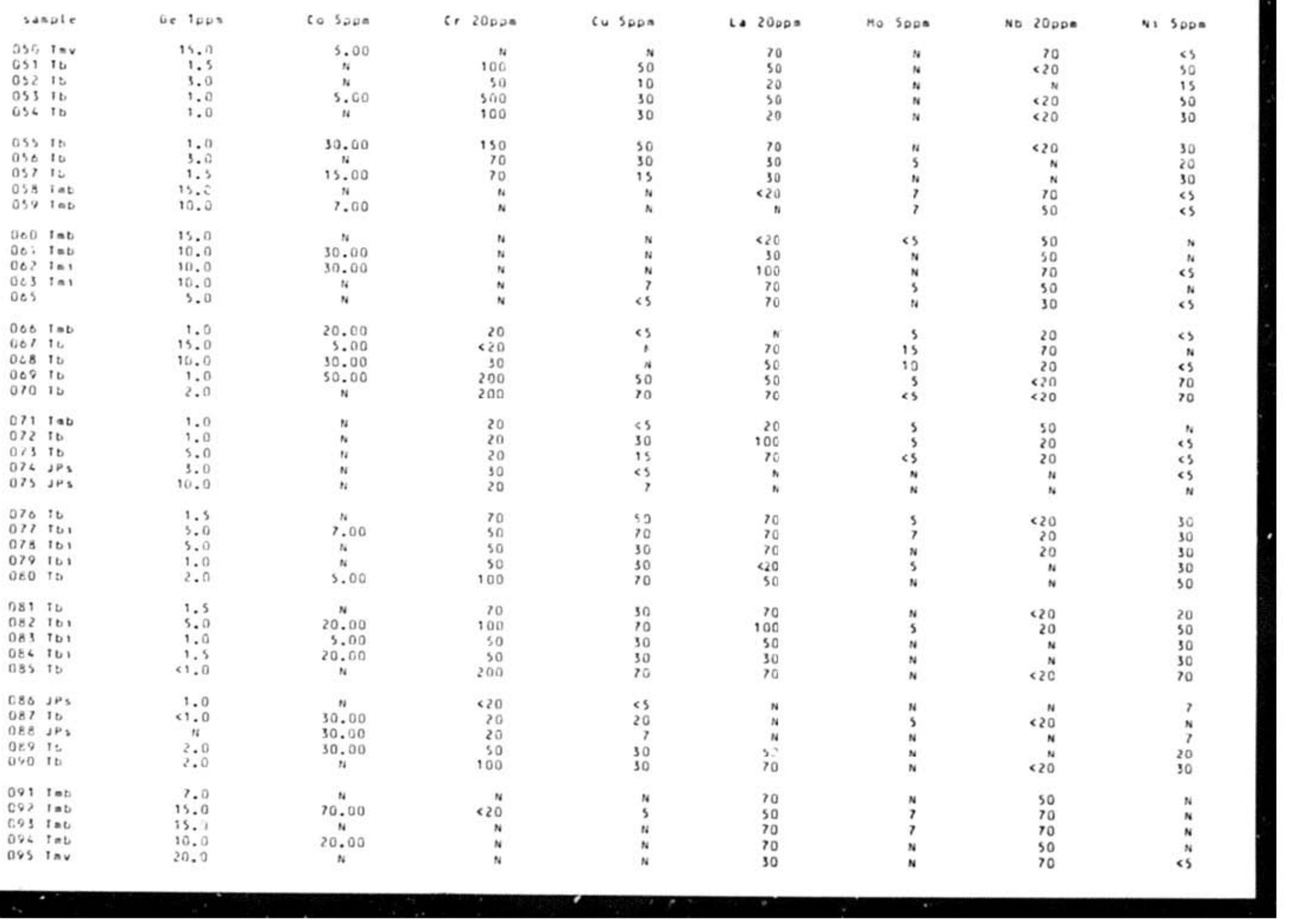


Appendia 1.--Rock analysis from the Mount Belknap catdera vicintty-econtinued

suple

$0 \cos \tan$

osi it

05? it

053 it

$056 \mathrm{tt}$

oss 10

05010

0,7 to

cos $1=0$

CS9 lat

DoD $\tan$

061 int

06? Ia

Oes ta

oos

Ces int

Q 07 10

008 to

071 tob

072 to

013 t

$012 \mathrm{JPs}$

$075 \mathrm{dt}$

010 its

077 to

$67 \mathrm{a}$ to

078 10,

080 it

$O B D$ It

$082 \mathrm{tt}$,

oes $1 \mathrm{t}$,

0 aे $1 \mathrm{th}$,

Des it

$0.30 \mathrm{JPS}$

Def is

asA $\triangle P$ :

$0 \times 9$ it

Q0.0 ic

091 int

092 tes

025 inc

$0 \% 6$ tos
ovs tas
Sn 1OPPE

$<10$
$n$
$n$
$n$
$n$
$n$
$n$
$N$
510
$N$
$N$
$n$
$N$
$n$
$N$

$n$

10

$N$

$n$

$" n$

$n-1,000$

1.600
700

500
700

300

700

500

700
300

4100

$<100$

700

2.000

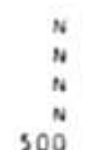

v 20000

$<20$
$<20$
$<20$
200
200
200
$N$
100
$N$
$<20$
$<20$
$<20$
$<20$
$N$
50

50

$<20$
$<20$

$<20$

ats

100

100
$\times 20$

$<2$

100
$n$
$n$

100

200

200

200

$n$
20
$<20$
200
200

$\quad n$
$<20$
$<20$

$<20$
200
Y 10pDo

50
30
30
30
20

20
30
30
30
10
10
20
50
30
20

so

50
20
50

30

15
20

30

30
30
50
20
30

20

30

30
30
30

$<10$

$<10$
$<10$

$<10$

30
30

30

30
30
30
$2+502=$

G. 10000

300
200
100
100
200

200
200
200
200
200
200
200
200
300
200

200

200

100
200

200

200

200

300

150

200

200

100

200

200

200

200

200
200

100

200

100

100

200

200

200

200
100

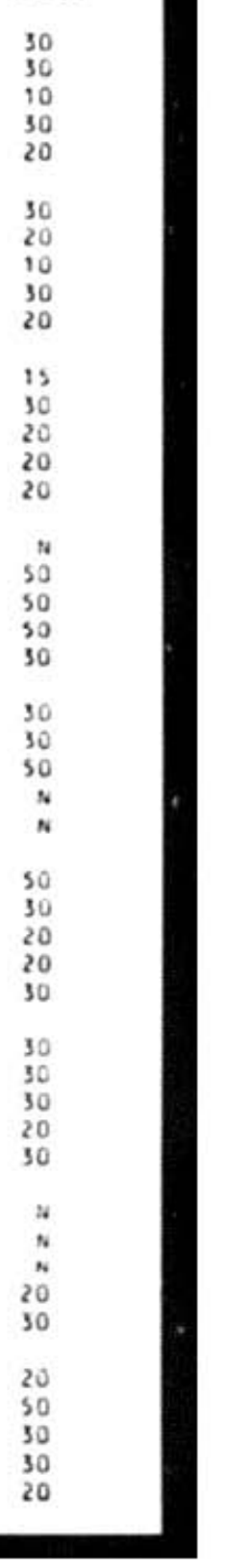


Appendia 1.- Rock analysis fron the Mount Belknap catdera vicinitye-continued

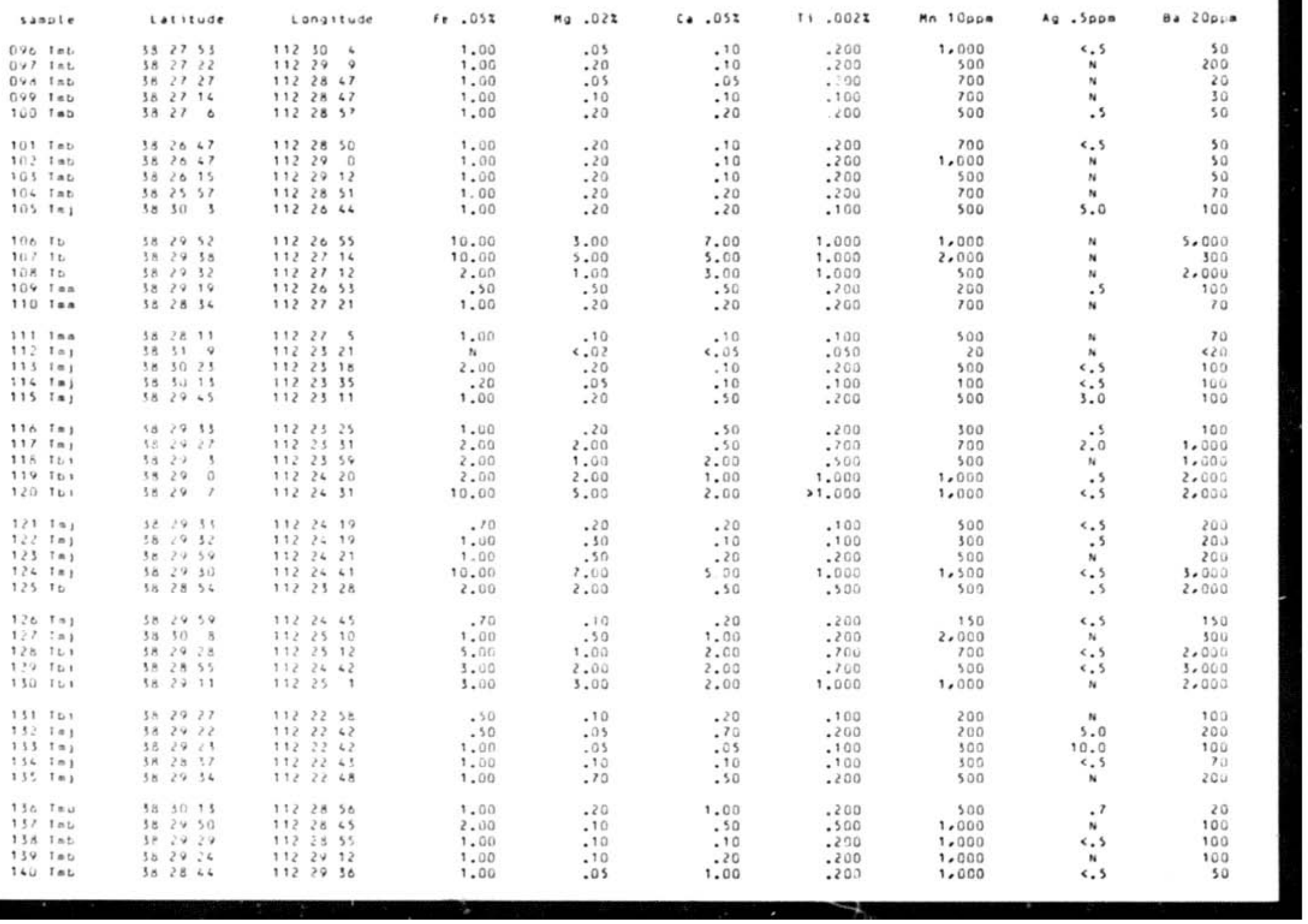




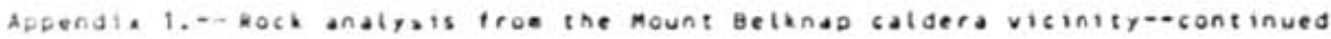

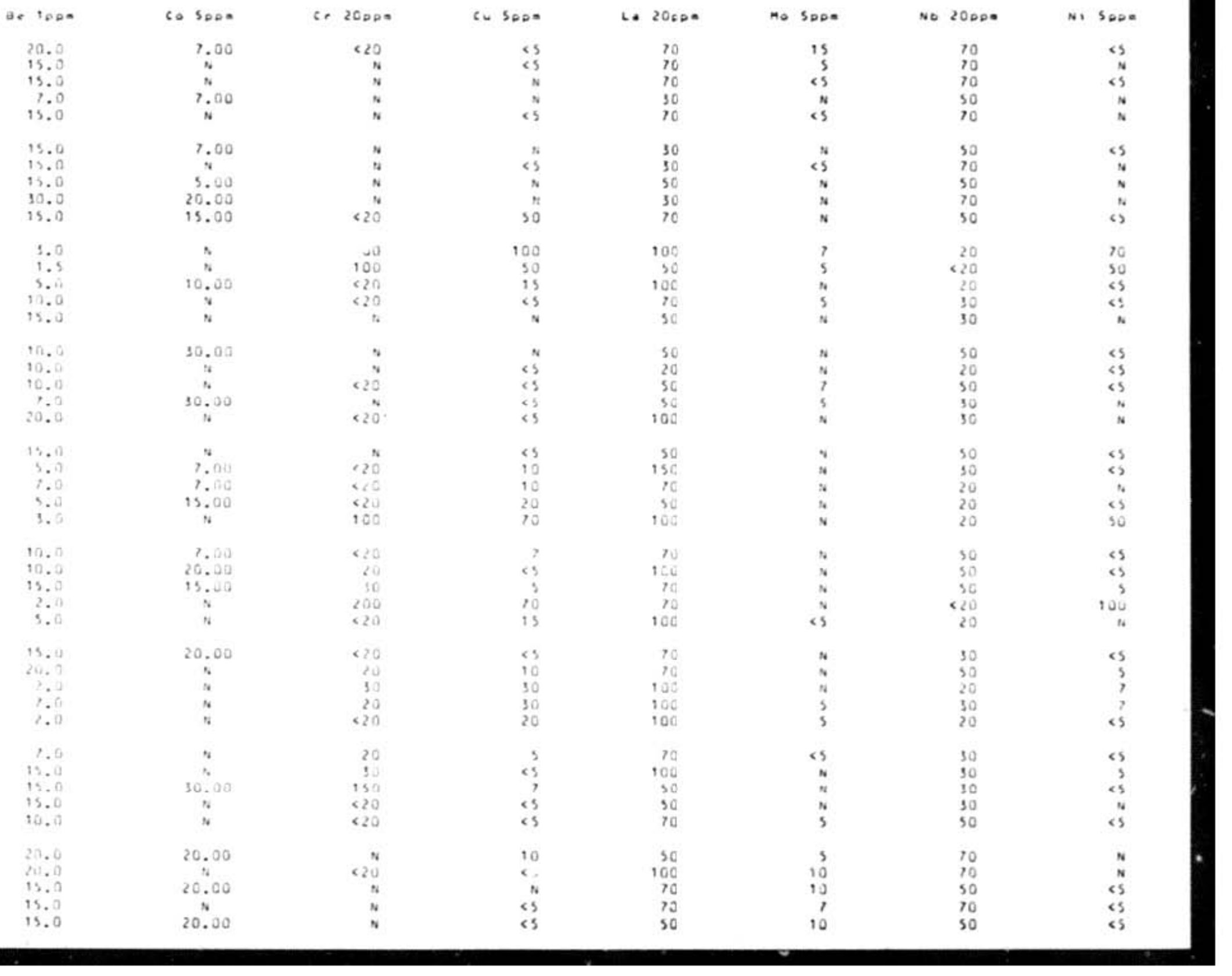




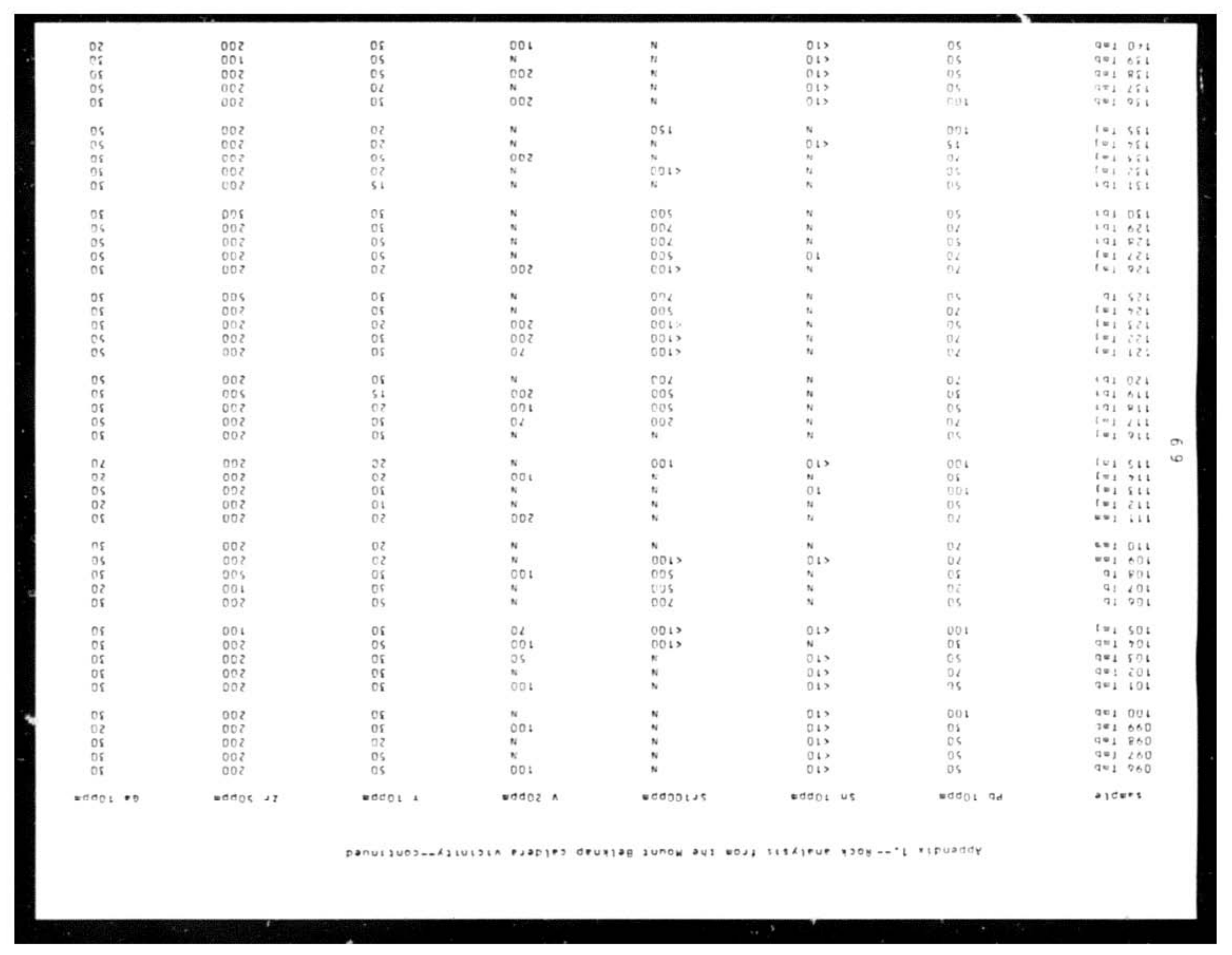




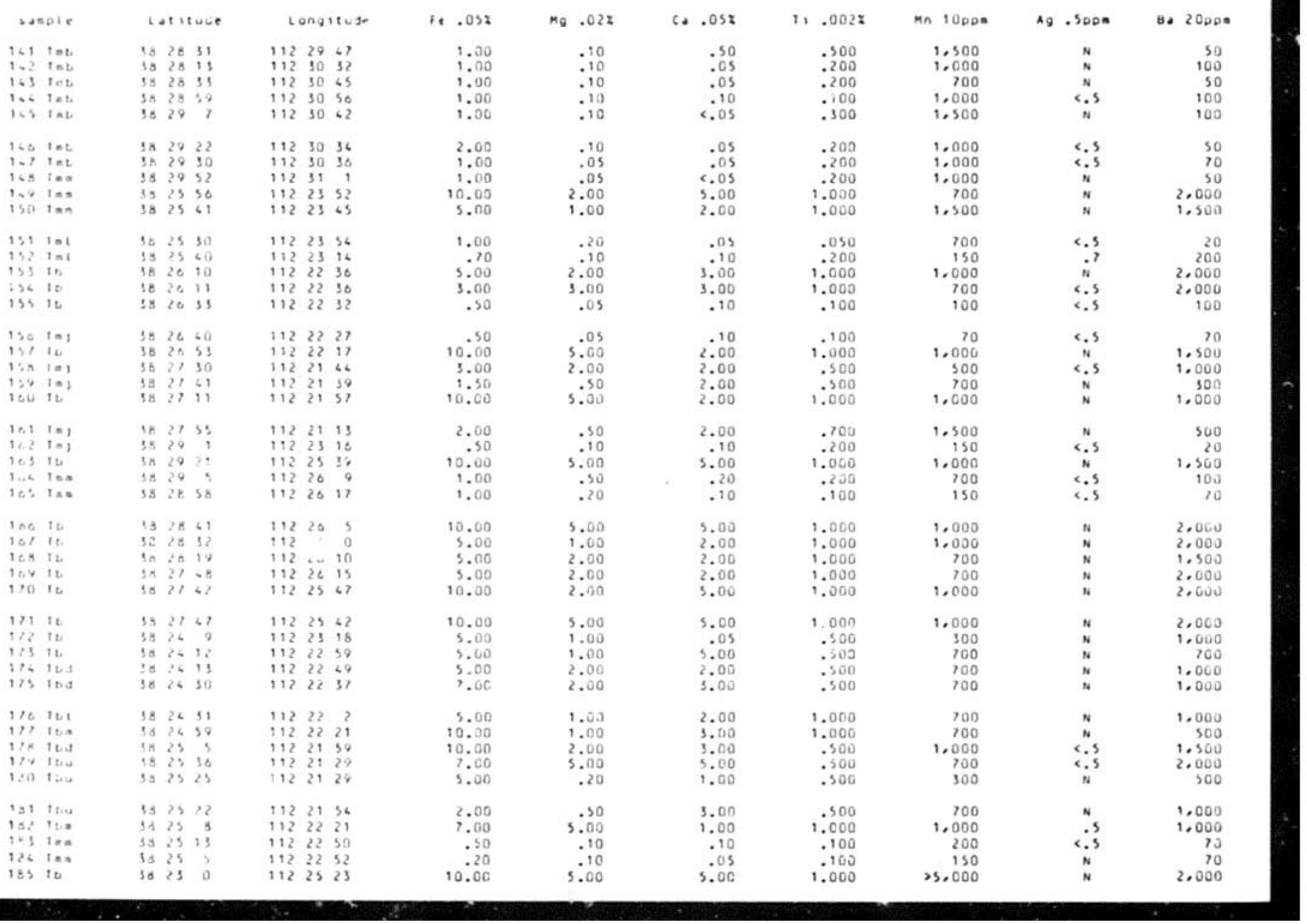


Appendix 1.Mock analysis tron the Mount Belknad caldera vicinityacontinued

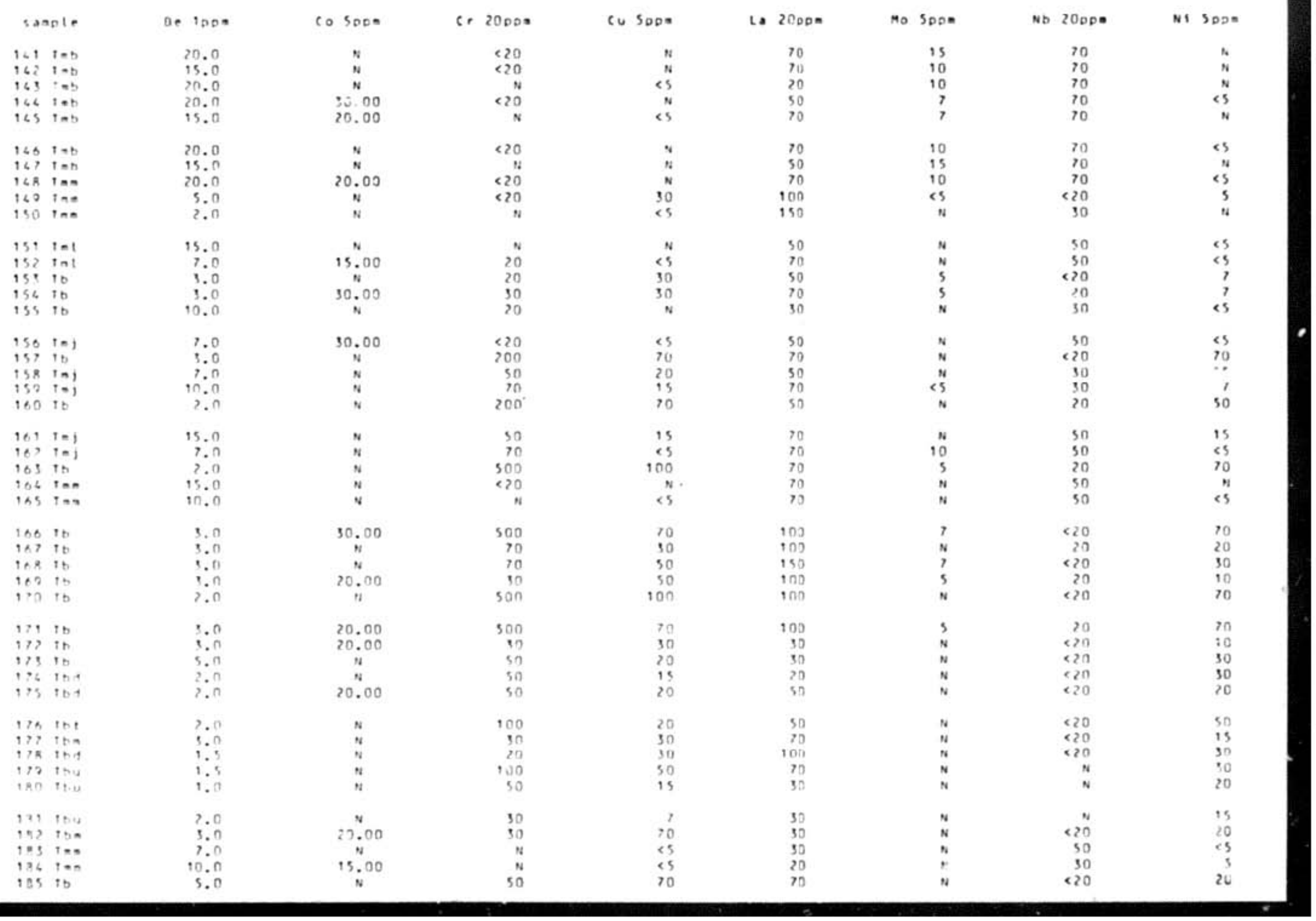


ADpendix 1.-pock analysis fros the Mount Belknad calders viteinitye-continued

sande

161 in

162 ind

$163 \quad \mathrm{mb}$

$166 \quad 1=0$

$145 \quad t=5$

$1<6 \quad t=5$

$167+96$

168 t $1 \mathrm{ma}$

160 to

150 ing

$15, \quad+a t$

$152 \mathrm{~T}=1$

155 in

15678

$156+101$

$157: 6$

158 ind

1,0
100

160 is

16) 19.

16 in

183 in

106100

105 10

$\cos 1$

167 T

$10 \times 10$

100 i

1,

179 it

$17 ?$

17\%

176 tod

its the

$170+10$

177 to

17810.

180 tbu

18) TBU

is? Tto

18310

$18670 \mathrm{am}$

185 it
Po 10Don

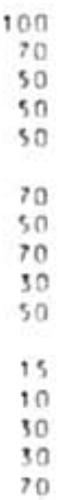

50
30
50
70
15

70
20
50

70

50
50
50
70
10

50
15
$\times 10$
10
20

10
30
30
30
30

30

10
20
15
70
50 sn 1000

$$
\begin{array}{r}
10 \\
\times 10 \\
5 \\
<10 \\
N \\
\times 10 \\
<10 \\
410 \\
N \\
N \\
N \\
N \\
N \\
N \\
N
\end{array}
$$

s+10000m

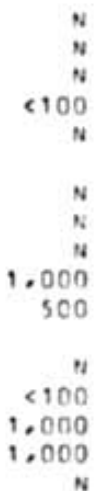

$n$
1,000
500
100
700

150

100

s

1.000

300
700

500
700

1.000

.000
700

700
200
700

700
$7 n 0$

700
700

1.500

1.000

700

700
500
$N$
$N$
700 y 20pon

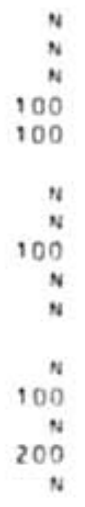

500

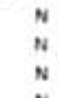

Y 10pose

70
30
20
30
50
50
50
30
50
50
30
20
30
30
10
20
30
30
30
30
30
20
30
20
15

30

50
30

30
30

30

50
15
30

20
20

20

20
30

30
20
30
15

is

20

30
15
10
$2+50000$

500

500

100

200

200

200
200

200

300

200

200

200
200

100

200

200

200
200

200
200

200

200
200

200

200

200
200

200

300
200

200

200

200

200
100

200

200
$20 n$

200
200

200

100

200

200

200
200
Ga 10ppo

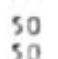

50

30

30

30
30
30

30
30

20

30
50

30

30

50
50

30
20

30
50

20

30
30

30

30
20

10

10
30

30

20
30

50
10

20

20 


\begin{tabular}{|c|c|c|c|c|c|c|c|c|c|}
\hline sasple & wetivate & congitude & 1. .05 & $" 0.022$ & c. $.05 z$ & (1.. $\mathrm{nn} 22$ & Ta & AQ SSDDA & $B, 20 p D A$ \\
\hline 190,001 & 132367 & 1122650 & 1.00 & .10 & .10 & $.50 n$ & 150 & $<.5$ & so \\
\hline $181=01$ & 1923 is & 11225 is & 1.00 & .50 & in & .200 & 25.000 & $\ddot{n}$ & 200 \\
\hline $188 \mathrm{~Tb}$ & 382328 & 1122536 & 10.00 & 5.00 & 5.00 & 1.00 ก & 2.000 & $n$ & 2.000 \\
\hline 180 to & 3823,3 & 112268 & 2.00 & $.5 n$ & 2.00 & sno & 500 & $n$ & 700 \\
\hline $100 \mathrm{to}$ & 38238 & 1122011 & 7.00 & 2.00 & 5.00 & $1.00 n$ & 1.000 & n & $1.00 n$ \\
\hline 101 ib & 592258 & $11226 \quad 28$ & 2.00 & 1.00 & 1.00 & 1.000 & 500 & $<.5$ & 500 \\
\hline 19218, & 382223 & 1122857 & 5.00 & 2.00 & 2.00 & $1 . n 00$ & 100 & $n$ & 1.000 \\
\hline 12515 & $3822 \quad 6$ & 1122712 & 2.00 & .50 & 2.00 & $1.00 n$ & 700 & N & 1.000 \\
\hline 126 in & $38>193$ & $112 \geqslant 32$ & 1.00 & .20 & .10 & $.20 n$ & 300 & $N$ & 500 \\
\hline 105 tb & 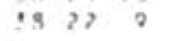 & $1, \quad 39$ & $2.0 n$ & 1.00 & .10 & .500 & 100 & n & 1,000 \\
\hline 106 to & (A, $, 2,2$ & $1, \geqslant 52$ & 2.00 & .02 & .05 &. $\operatorname{sen}$ & 50 & $n$ & 1.500 \\
\hline 107 to & 382217 & 1122826 & חח & 3.00 & 3.00 & 1.000 & 1.000 & $n$ & 1.500 \\
\hline 13918 & $3 \times 22 \geqslant 1$ & $\therefore \begin{array}{llll}12 & 20 \quad 3\end{array}$ & 10.00 & $? .00$ & 3.00 & 1.000 & no & n & $1.00 n$ \\
\hline 10018 & 392221 & 1122969 & 1.00 & .5 .7 & .10 & .500 & 50 & .5 & 500 \\
\hline $200 \mathrm{Tm}$ & 382812 & 1122751 & 1.00 & .20 & .20 & 1.000 & 700 & c.s & iso \\
\hline $201,10$. & I 212 ? & 1,2288 & 1.00 & .50 & .50 & .200 & $\sec$ & c.s & 100 \\
\hline$\ldots>$ tan & 382753 & 1122821 & .50 & .05 & .05 & .200 & 300 & i & , \\
\hline 203 ind & 39 is 57 & $1: 2 \quad 287$ & $\therefore .00$ & .20 & .10 & .200 & 1,500 & c.5 & 100 \\
\hline $206 \mathrm{tan}$ & IR 2866 & $\because 22 \pi, 1$ & 1.00 & .20 & .10 & $.2 n o$ & 500 & c.s & o \\
\hline $20510 b$ & 382028 & $112 \quad 28 \quad 12$ & 1.00 & .05 & .10 & .200 & 150 & c.s & 70 \\
\hline $20 c \quad \ln b$ & 382623 & $11228 \quad 2$ & 1.00 & .10 & .10 & .200 & 200 & c.s & so \\
\hline 20 , int & 182612 & $1, \geqslant 276$ & 1.00 & .20 & .10 & .200 & 500 & .3 & 70 \\
\hline $20 \Omega \quad t=0$ & 382536 & $112 \geqslant$ \&s & .50 & .10 & .10 & .200 & 200 & .5 & 100 \\
\hline $200 \quad i n b$ & 382718 & 1122756 & 2.00 & .10 & .10 & .200 & 1.000 & c.s & 100 \\
\hline $2101=0$ & 382732 & 1122736 & 1.00 & .20 & .20 & $.10 \pi$ & 500 & $n$ & 70 \\
\hline $211+0$ & 38735 & 1122720 & 1.00 & .20 & .20 & .200 & no & n & 70 \\
\hline $212 \quad t=b t$ & 382560 & 11226 in & 1.00 & .20 & .10 & .100 & 3 no & $n$ & so \\
\hline $213 t=0$ & $3825<0$ & 1123630 & $.5 n$ & .10 & .05 & .100 & 500 & c. 5 & 20 \\
\hline $216 \quad 1=01$ & $\begin{array}{lll}38 & 26 & 0\end{array}$ & 1122631 & .50 & $\therefore 0$ & .20 & .200 & 700 & $\therefore s$ & 100 \\
\hline $215 \quad 1=1$ & 382832 & 1,22618 & .50 & .80 & .05 & .100 & 300 & $\therefore 5$ & 50 \\
\hline $210+01$ & $3926>0$ & 1122627 & 1.00 & .10 & .10 & .200 & 150 & 6.5 & 100 \\
\hline sol $i=b$ & 182018 & 11231 55 & .70 & .20 & .10 & .100 & 900 & n & 30 \\
\hline 502 it & 382853 & 11231,65 & 10.00 & 2.00 & 2.00 & 1.000 & 1,500 & $n$ & 2.000 \\
\hline $5 n$ is & 182021 & 112923 & ?.0n & 1.00 & 1.00 & .500 & קon & c. 5 & 700 \\
\hline $506 \operatorname{tav}$ & 1376, & $1: 23025$ & 1.00 & .10 & .10 & .200 & 1.000 & $\ddot{N}$ & 70 \\
\hline $505 \tan$ & $3325 \quad 51$ & $11230 ?$ & $1.0 n$ & .05 & e.ns & .200 & 1.000 & $n$ & 20 \\
\hline 500 las & 3925, & 1123117 & $\therefore .00$ & .50 & .20 & .200 & 1.000 & c.s & 90 \\
\hline 507 tav & 372646 & 112355 & 1.00 & .67 & -10 & .200 & 1.000 & e.s & so \\
\hline 501 ind & 382622 & 1123055 & 1.00 & .20 & 1.00 & .200 & 1.000 & e. 5 & 100 \\
\hline $500 \quad=\mathrm{b}$ & 382610 & 112310 & 2.00 & .20 & .10 & .200 & 1,000 & .5 & 200 \\
\hline $\sin 100$ & $3,2,1$ & 11231 in & 1.00 & $\therefore 0$ & .10 & $.20 n$ & 1,500 & $n$ & 70 \\
\hline sit 100 & $33 \geqslant 65$ & 1123125 & 1.00 & .20 & $\therefore 10$ & .200 & 700 & $n$ & 100 \\
\hline $5: 2+00$ & $3826 \quad 6$ & 1123133 & 1.00 & .10 & .10 & $>1.000$ & 700 & N & 100 \\
\hline 5,3100 & 382626 & 1123151 & 1.00 & .10 & .10 & .200 & 700 & $v$ & 100 \\
\hline 516100 & $98 \quad 2657$ & $11232 \quad 2$ & so & .20 & .50 & .100 & 500 & $<.5$ & 100 \\
\hline
\end{tabular}




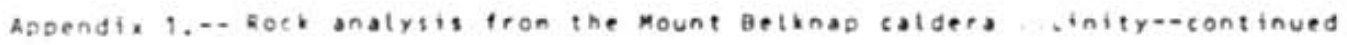

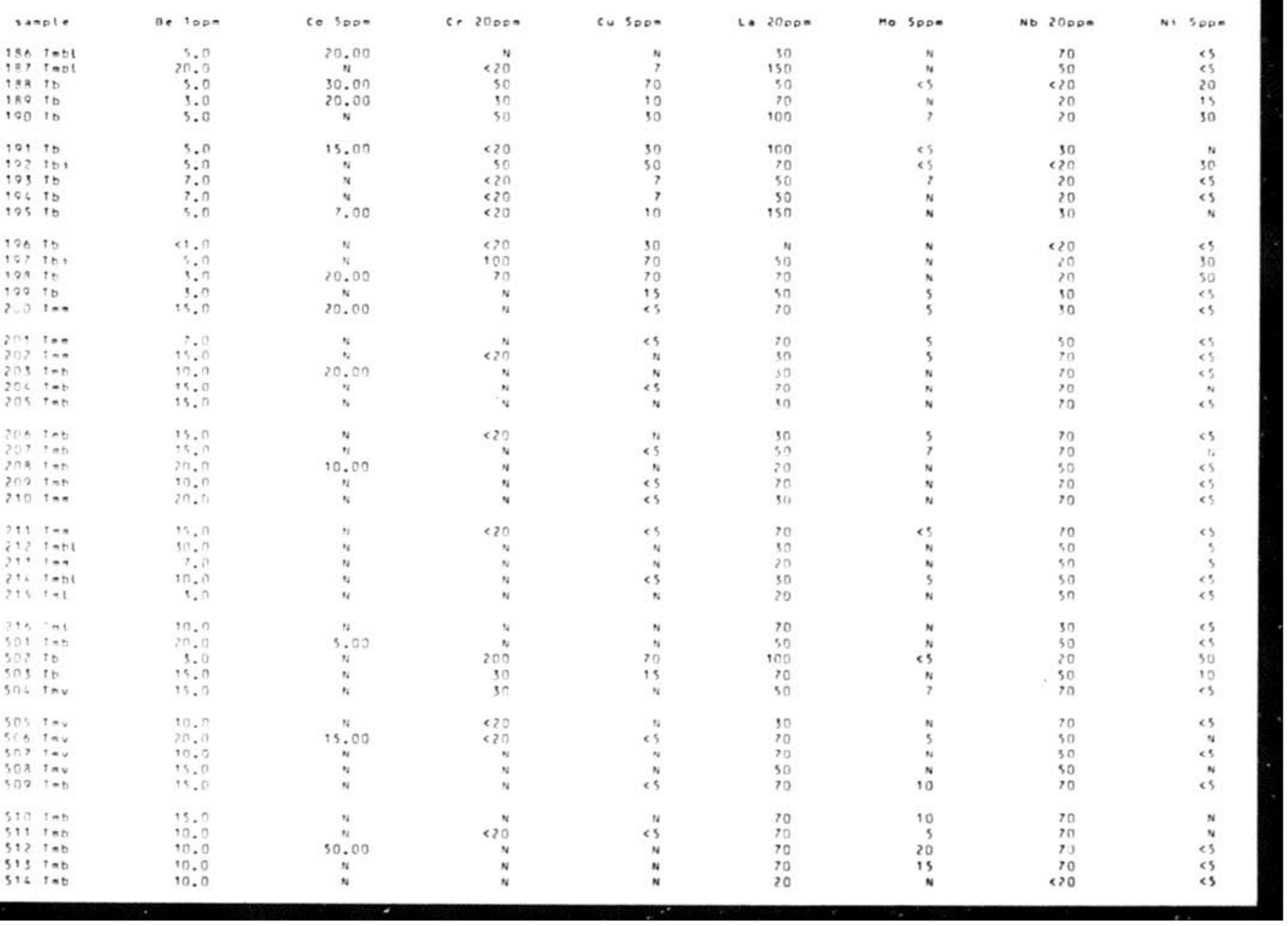


Appendt. 1.. Rock anstrsis fron the mount getknad caldera vicinitye-continued

\begin{tabular}{|c|c|c|c|c|c|c|c|}
\hline sunole & Do 10000 & $\sin 1000=$ & sor10000n & $\checkmark 20000$ & ropos & $z=50000$ & GS 1000 \\
\hline 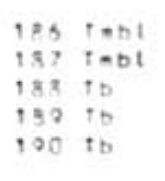 & $\begin{array}{r}30 \\
170 \\
30 \\
30 \\
30\end{array}$ & 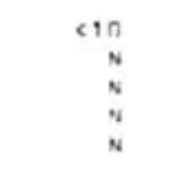 & $\begin{array}{r}100 \\
700 \\
300 \\
500\end{array}$ & $\begin{array}{c}200 \\
n \\
200 \\
100 \\
n\end{array}$ & $\begin{array}{l}30 \\
30 \\
30 \\
30 \\
30 \\
30\end{array}$ & $\begin{array}{l}300 \\
200 \\
200 \\
200 \\
200\end{array}$ & $\begin{array}{l}50 \\
30 \\
30 \\
20 \\
30\end{array}$ \\
\hline $\begin{array}{ll}109 & 10 \\
02 & 10 \\
03 & 10 \\
03 & 10 \\
205 & 10\end{array}$ & $\begin{array}{l}30 \\
30 \\
30 \\
30 \\
20\end{array}$ & $\begin{array}{r}10 \\
\stackrel{3}{*} \\
10 \\
n\end{array}$ & $\begin{array}{l}200 \\
300 \\
500 \\
100 \\
100\end{array}$ & $\begin{array}{r}100 \\
n \\
n \\
n \\
100\end{array}$ & $\begin{array}{l}30 \\
20 \\
30 \\
30 \\
30\end{array}$ & $\begin{array}{r}1,000 \\
200 \\
500 \\
200 \\
300\end{array}$ & $\begin{array}{l}30 \\
30 \\
15 \\
20 \\
30\end{array}$ \\
\hline $\begin{array}{ll}100 & \\
10 & \\
104 & 10 \\
180 & 10 \\
200 & \text { in }\end{array}$ & $\begin{array}{l}20 \\
20 \\
30 \\
50\end{array}$ & $\begin{array}{r}v \\
n \\
i \\
<0 \\
n\end{array}$ & $\begin{array}{r}200 \\
700 \\
700 \\
200 \\
600\end{array}$ & $\begin{array}{r}n \\
200 \\
200\end{array}$ & $\begin{array}{r}10 \\
30 \\
30 \\
20 \\
30\end{array}$ & $\begin{array}{l}100 \\
500 \\
200 \\
200 \\
100\end{array}$ & $\begin{array}{l}5 \\
15 \\
30 \\
20 \\
20\end{array}$ \\
\hline 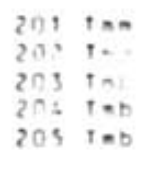 & $\begin{array}{l}70 \\
50 \\
30 \\
30 \\
50\end{array}$ & 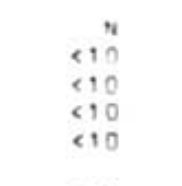 & $\begin{array}{r}100 \\
n \\
\vdots \\
\vdots \\
n\end{array}$ & $\begin{array}{r}n \\
N \\
N \\
N\end{array}$ & $\begin{array}{l}20 \\
30 \\
30 \\
50 \\
20\end{array}$ & $\begin{array}{l}200 \\
100 \\
200 \\
200 \\
200\end{array}$ & $\begin{array}{l}30 \\
20 \\
30 \\
50 \\
30\end{array}$ \\
\hline $\begin{array}{ll}200 & 1=0 \\
207 & 1=0 \\
208 & 1=0 \\
200 & 1=0 \\
210 & 1=0\end{array}$ & $\begin{array}{l}70 \\
30 \\
30 \\
50 \\
50\end{array}$ & $\begin{array}{l}<10 \\
310 \\
410 \\
10 \\
4\end{array}$ & $\begin{array}{l}n \\
n \\
n \\
n\end{array}$ & 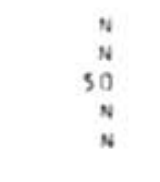 & $\begin{array}{l}30 \\
30 \\
30 \\
30 \\
50\end{array}$ & $\begin{array}{l}200 \\
300 \\
200 \\
200 \\
300\end{array}$ & $\begin{array}{l}30 \\
30 \\
30 \\
30 \\
20\end{array}$ \\
\hline 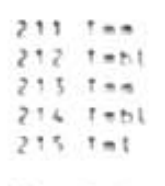 & $\begin{aligned} 30 \\
15 \\
10 \\
10 \\
10 \\
10\end{aligned}$ & $\begin{array}{r}10 \\
8 \\
3 \\
3\end{array}$ & $\begin{array}{l}n \\
8 \\
8 \\
4 \\
4\end{array}$ & s & $\begin{array}{l}30 \\
30 \\
30 \\
30 \\
30 \\
20\end{array}$ & $\begin{array}{l}200 \\
200 \\
200 \\
200 \\
200\end{array}$ & $\begin{array}{l}20 \\
\text { is } \\
\text { is } \\
\text { is } \\
\text { is }\end{array}$ \\
\hline $\begin{array}{ll}210 & 1=1 \\
30 & 1=0 \\
3 n 2 & 10 \\
501 & 10 \\
3 n c & i n d\end{array}$ & $\begin{array}{l}10 \\
30 \\
30 \\
10\end{array}$ & $\begin{array}{r}v \\
v \\
4\end{array}$ & $\begin{array}{r}200 \\
200 \\
50\end{array}$ & $\begin{array}{r}20 \\
30 \\
n \\
n\end{array}$ & $\begin{array}{l}20 \\
30 \\
50 \\
50 \\
50\end{array}$ & $\begin{array}{l}200 \\
200 \\
200 \\
300 \\
200\end{array}$ & $\begin{array}{l}15 \\
30 \\
50 \\
30 \\
30\end{array}$ \\
\hline $\begin{array}{ll}500 & t=0 \\
500 & 100 \\
500 & 102 \\
500 & 0\end{array}$ & $\begin{array}{l}10 \\
100 \\
100 \\
30 \\
70\end{array}$ & $\begin{array}{l}8 \\
10 \\
10 \\
10 \\
15\end{array}$ & $\underset{500}{N}$ & $\begin{array}{l}N \\
N \\
N \\
N \\
N\end{array}$ & $\begin{array}{l}30 \\
30 \\
30 \\
30 \\
30\end{array}$ & $\begin{array}{l}200 \\
200 \\
200 \\
200 \\
200\end{array}$ & $\begin{array}{l}3 \\
50 \\
50 \\
30 \\
50\end{array}$ \\
\hline $\begin{array}{ll}510 & t=0 \\
311 & t=5 \\
51,2 & i=0 \\
513 & i n t \\
51, & i=0\end{array}$ & $\begin{array}{l}70 \\
70 \\
10 \\
70 \\
70\end{array}$ & $\begin{array}{l}10 \\
10 \\
10 \\
10 \\
n\end{array}$ & $\begin{array}{l}n \\
n \\
n \\
n \\
n \\
n\end{array}$ & $\begin{array}{r}20 \\
200 \\
n \\
n\end{array}$ & $\begin{array}{l}50 \\
50 \\
50 \\
50 \\
10\end{array}$ & $\begin{array}{l}200 \\
200 \\
200 \\
200 \\
100\end{array}$ & $\begin{array}{l}50 \\
50 \\
50 \\
30 \\
30\end{array}$ \\
\hline
\end{tabular}




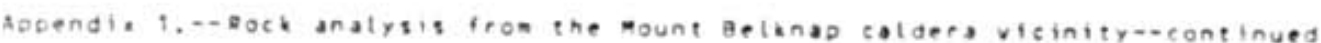

\begin{tabular}{|c|c|c|c|c|c|c|c|c|c|c|}
\hline$\because$ & note & tetetude & Long.tud & 1.0058 & 70.027 & 60.058 & t, eoriz & ma 1000a & AO . SODA & 8.20000 \\
\hline $\begin{array}{l}\text { sis } \\
\text { sis }\end{array}$ & $i=0$ & $32 \geqslant 3 \%$ & $\begin{array}{lll}112 & 31 & 50 \\
12 & 3 & 0\end{array}$ & 1.00 & .05 & .05 & .100 & sno & $e .5$ & 100 \\
\hline & $\rightarrow \rightarrow 0$ : & 3424 is & 112356 & & 3.07 & 3.00 & 1.000 & 1.000 & $<.5$ & 1.000 \\
\hline & to & 38,3 & 1123263 & $\therefore 50$ & $: 10$ & .10 & $\therefore 80$ & 150 & 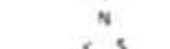 & 100 \\
\hline 598 & 10 & 382315 & 1123236 & $\therefore 00$ & 2.00 & 5.00 & 90000 & 150 & is & $\begin{array}{l}1.000 \\
2.000\end{array}$ \\
\hline 520 & 10 & $18 \% 8$ & 1.23810 & 5.00 & 2.00 & 5.00 & 1.000 & 500 & $c, 5$ & 1.500 \\
\hline $3 \because$ & $i=t$ & $38,3=2$ & 13 t2 in & $\therefore 00$ & .10 & .10 & .200 & 1.000 & 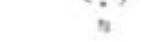 & 50 \\
\hline $52 ?$ & $\because n$ & $\because 2 \geqslant 3$ & $1,2 ? 36$ & 5.00 & 3.00 & 3.00 & .500 & 1.000 & s & 1.000 \\
\hline 325 & $t_{i=0}$ & $\begin{array}{lll}5 & 2 & 59 \\
18 & 22 & 5\end{array}$ & $\begin{array}{lll}112 & 11 \\
112 & 16\end{array}$ & $\therefore 50$ & .05 & .03 & $\because 900$ & 50 & $\therefore$ & 50 \\
\hline & & & & & & .05 & .200 & 150 & 4.5 & 90 \\
\hline 325 & $i=0$ & $\begin{array}{lll}15 & 35 & 3 \\
18 & 3 & 3\end{array}$ & $\begin{array}{lll}112 & 39 \\
112 & 30\end{array}$ & $\therefore$ & .25 & .10 & .200 & 10 & $e .5$ & 100 \\
\hline $5: 7$ & +00 & 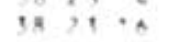 & , "? & $\because 00$ & .20 & 1.00 & .200 & 200 & $<.5$ & 70 \\
\hline 523 & 100 & 192323 & $, 12,3$, & $\because: 00$ & $: 20$ & .10 & .200 & 1.000 & v & 50 \\
\hline 520 & 100 & $3821>8$ & $112 \quad 30 \quad 52$ & i.on & .20 & .20 & .250 & ?ac & $\therefore 5$ & 50 \\
\hline 590 & $10 b$ & 382360 & $1,2 \geqslant 23$ & 1,00 & 10 & & & & & \\
\hline 339 & $i=b$ & 382531 & $113>26$ & 1.00 & .20 & 20 & -200 & 500 & $\because 5$ & 70 \\
\hline $53 ?$ & $t \rightarrow 0$ & $13 \geqslant 5$ & $11220 \quad 23$ & $\therefore 00$ & .10 & .20 & .200 & $\begin{array}{l}500 \\
500\end{array}$ & $\because 5$ & 50 \\
\hline 53 & $\theta$ & $1-2612$ & 1122039 & $\because .00$ & .10 & .20 & 200 & 300 & $\therefore 5$ & 50 \\
\hline 536 & 100 & $1826>3$ & $11220 \quad 7$ & 1.00 & .10 & .00 & .200 & soo & i & 70 \\
\hline $3: 5$ & $\because$ & $\because 2 \geqslant 6<2$ & 122942 & 1.00 & .10 & .20 & הס2. & 500 & $\leftrightarrow s$ & 0 \\
\hline 395 & $\because=t$ & 982696 & $1+2 \quad 2369$ & 1.00 & .10 & .20 & .200 & 300 & $\therefore 5$ & To \\
\hline 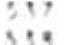 & $\because n$ & 58263 & $\because \because 2$ is 5 & .30 & .03 & . cs & .200 & 100 & e.s & 100 \\
\hline 500 & $\ln 0$ & $\begin{array}{lll}38 & 26 & 16 \\
18 & 26 & 66\end{array}$ & 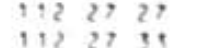 & $\therefore 50$ & $\because 20$ & .10 & .100 & 100 & 4.5 & , 0 \\
\hline 560 & $\therefore$ & & & . पu & .10 & .0 & .200 & 190 & $\leftrightarrow$ & 70 \\
\hline 96, & $i_{i \rightarrow b}$ & 2,25 & 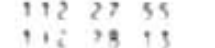 & $\because .00$ & .10 & .10 & .100 & 200 & $c .5$ & so \\
\hline 562 & $\cdots$ & 17250 &, 72 s 28 & $\begin{array}{l}1.00 \\
.05\end{array}$ & .05 & $\therefore 20$ & .200 & 500 & $N$ & 30 \\
\hline 563 & 100 & 132527 & $112 \mathrm{sin} 63$ & $\therefore .00$ & $\therefore 0$ & $\begin{array}{r}2.00 \\
.20\end{array}$ & .200 & 300 & 43 & 0 \\
\hline 566 & the & $38>253$ & 1123030 & 1.50 & .20 & .so & .500 & 800 & $\therefore$ & 100 \\
\hline 565 & 10 & & $192 \times 10$ & & $2 \pi$ & 80 & & & $\cdots$ & 100 \\
\hline 565 & $\tan$ & 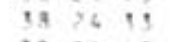 & $1: 22020$ &.$>0$ & $\because 0$ & $\because 0$ & $\because 00$ & 300 & $n$ & 90 \\
\hline 567 & 100 & $33>6 \quad 6$ & 1122028 & 1.00 & . & .90 & .100 & 300 & $\because 3$ & 0 \\
\hline $5<3$ & tet & 382636 & 1122825 & 1.00 & .20 & .70 & $.2 \mathrm{rm}$ & no & $\because 3$ & 0 \\
\hline 560 & $t=0$ & $1825 \quad 6$ & $11220 \quad 1$ & 1.00 & $.2 n$ & $\therefore 0$ & .050 & 150 & $\therefore s$ & 30 \\
\hline 557 & to. & 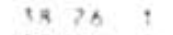 & 1123260 & 10.00 & 5.00 & 3.00 & 1.200 & 1.000 & $v$ & 1,500 \\
\hline & its. & " $>A$ & $1,732=0$ & 10.00 & 5.00 & 5.00 & $1.00 n$ & 1,000 & $\checkmark$ & (2000 \\
\hline 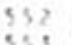 & $\because=1$ & $\because, y$, n & $\because \because 10,0$ & $\because .00$ & .20 & .10 & $.5 \mathrm{seg}$ & 700 & c.s & 30 \\
\hline 556 & & 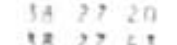 & 112405 & 1.00 & .27 & .13 & .90 & 50 & 45 & 30 \\
\hline 556 & $10 x$ & 182769 & 1250 & 1.00 & .10 & .10 & .200 & 1.000 & 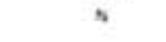 & 10 \\
\hline 555 & 100 & 332765 & & 1.00 & .10 & .05 & .200 & 1.000 & 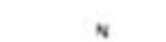 & 50 \\
\hline 550 & tos. & 32329 & 13,312 & 1.00 & .50 & 1.00 & .100 & 1.500 & 4.5 & $\because 0$ \\
\hline 55 & $i^{\circ}$ & $13 ? 7 \div 2$ & 313910 & 2.00 & .10 & .10 & .050 & 1.000 & $<.5$ & 70 \\
\hline 550 & 10 & $\begin{array}{lll}3 & 27 & 3 \\
3 A & 28 & 13\end{array}$ & $\begin{array}{lll}1,12 & 31 & 59 \\
1,2 & 32 & 6\end{array}$ & $\begin{array}{r}10.00 \\
3.00\end{array}$ & 3.00 & 5.00 & $\because .000$ & 300 & $\because 5$ & $\because 000$ \\
\hline & & रूत & & & & 2.00 & 1.000 & 700 & c.s & 2.000 \\
\hline
\end{tabular}


Appendif 1.--Rock analysis froe the Mount Betanap catdera vicinity-econtinued

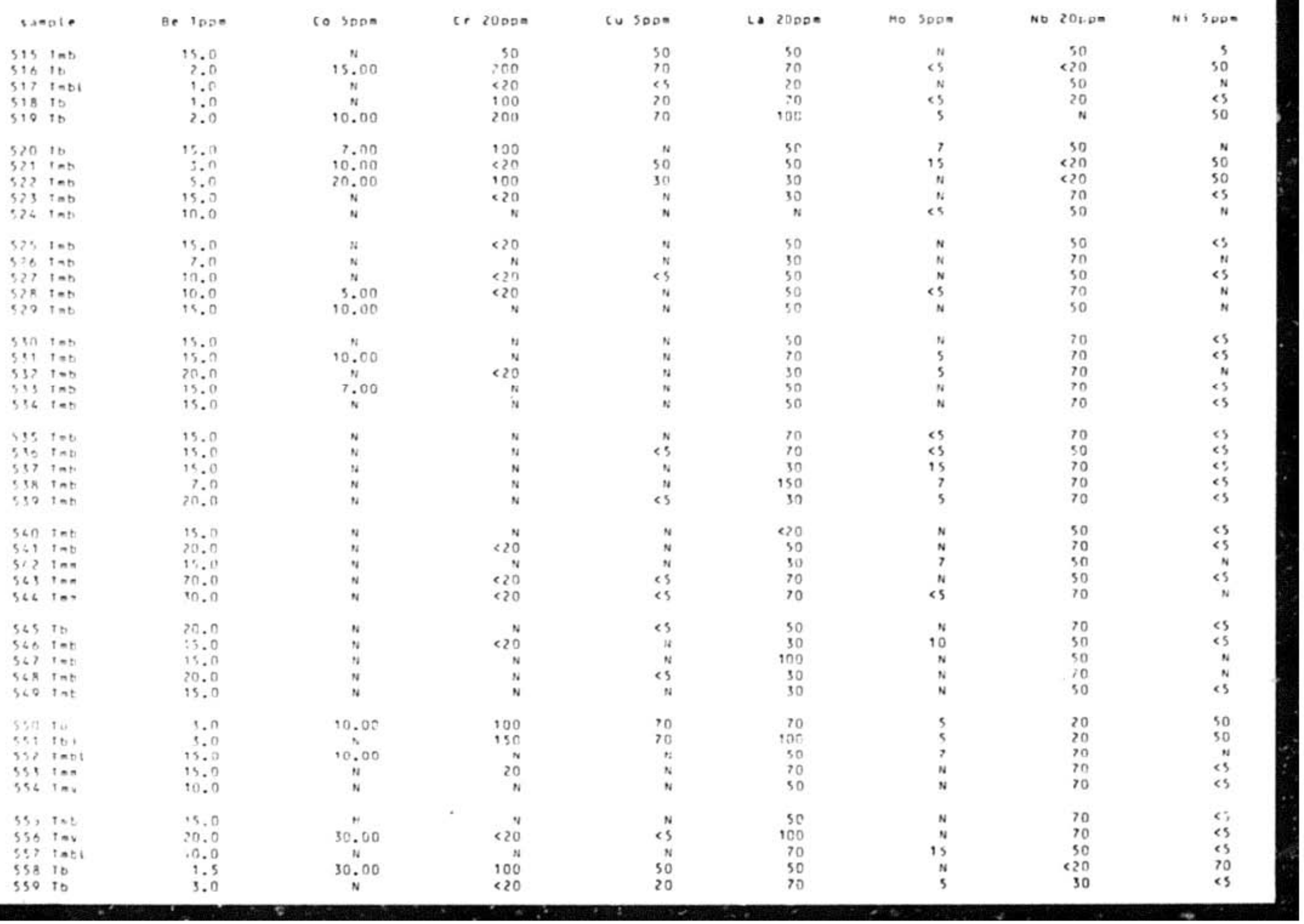


Appendix 1,-a Rock analysts fron the Mount Belknap catdera vicinityacontinued

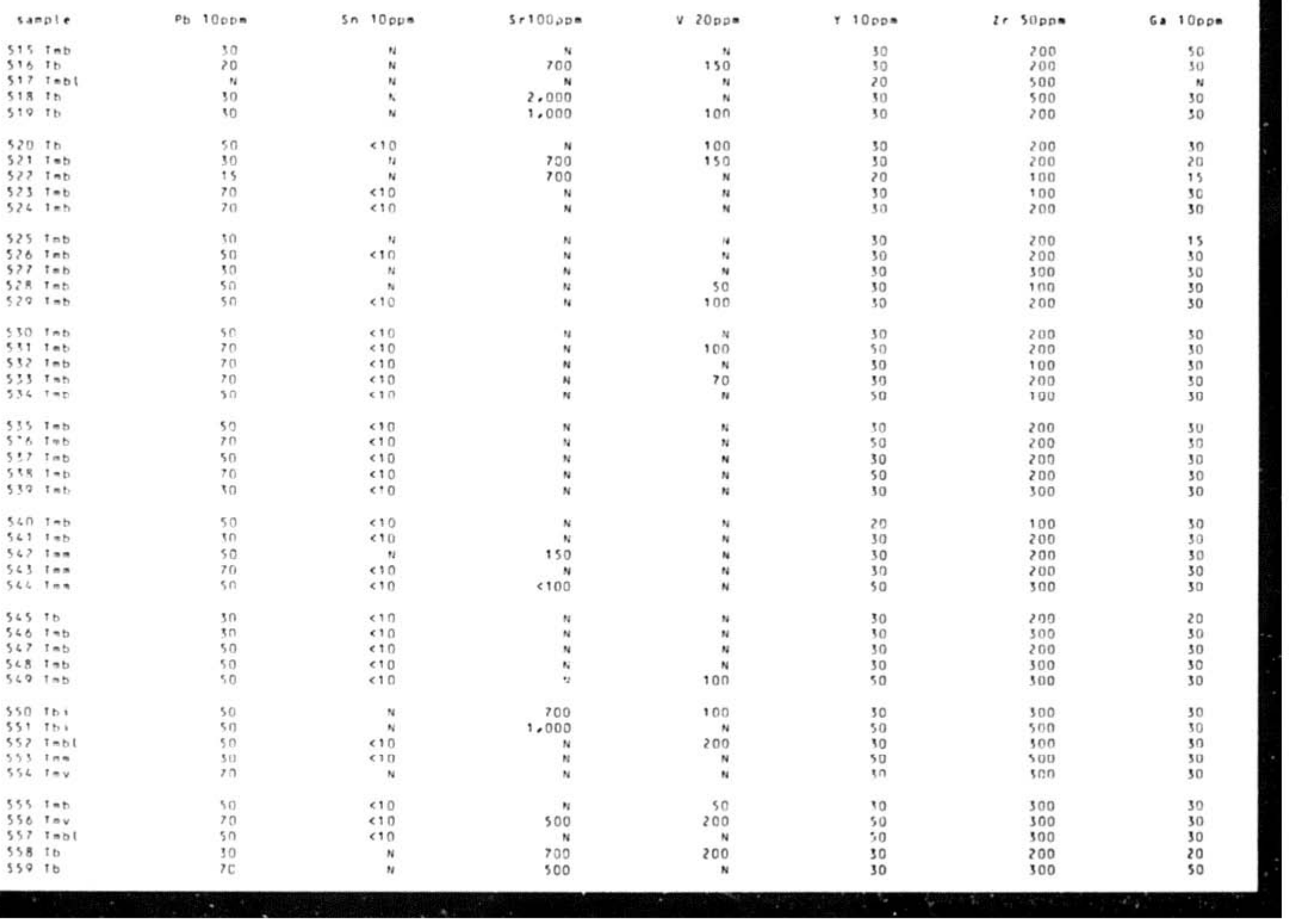




\begin{tabular}{|c|c|c|c|c|c|c|c|c|c|c|}
\hline \multicolumn{2}{|c|}{ sasole } & tatitude & Langleude & \multirow{2}{*}{10.052} & $M g .022$ & C. .05z & If .0022 & Mn 1 nope & Ao .5000 & B. $200 D=$ \\
\hline & ib & $3828 \quad 0$ & 1123134 & & 2.00 & 3.00 & .530 & & ง & 1.500 \\
\hline ss: & ${ }_{b}$ & $35>917$ & 1123120 & 2.00 & 1.00 & 3.00 & :3no & 1,000 & $n$ & 700 \\
\hline S6? & 10 & in 2837 & 1123152 & 9.00 & 1.00 & 5.00 & 1.000 & 1.000 & c.s & $\therefore .000$ \\
\hline 553 & $\operatorname{lat}$ & $38283 n$ & 112323 & 1.00 & .10 & .05 & .100 & 700 & $N$ & 30 \\
\hline 506 & $\tan \theta$ & 382833 & 1123220 & 2.00 & 1.00 & 2.00 & .500 & 1,000 & $<.5$ & 50 \\
\hline 565 & 16 & 182926 & 1123266 & 7.00 & .00 & 5.00 & 1.000 & 700 & $n$ & 1.000 \\
\hline $50 x$ & is & 38 is 20 & 112 3) 66 & $10.0 n$ & 5.00 & 5.00 & 1.000 & 700 & N & 2,000 \\
\hline 507 & $1 \mathrm{~b}$ & is $>8$ ? & 1123251 & 10.00 & 2.00 & 5.00 & 1.000 & 300 & <.s & 2.000 \\
\hline 508 & to & $3828 ;$ & 1123237 & 10.00 & 5.00 & 10.00 & .500 & 1.500 & $n$ & 1.000 \\
\hline 500 & ib & $33 \rightleftharpoons 3$. & 1123230 & 10.00 & 5.00 & 5.00 & .500 & 1,500 & n & 500 \\
\hline 570 & $\tan t$ & 39207 & 112786 & 1.00 & .ns & $<.05$ & .200 & 200 & 2.5 & 50 \\
\hline $5 \geqslant 1$ & $t a n$ & 182618 & 1123032 & $.5 n$ & .05 & $\therefore 05$ & .100 & 100 & $\therefore 3$ & 30 \\
\hline s? & $t=0$ & 3826, & 112286 & 1.00 & .20 & .20 & .200 & 200 & $\because 5$ & so \\
\hline 573 & $i=n$ & 382352 & 1122610 & 1.00 & .10 & .05 & .100 & 300 & $\therefore 5$ & so \\
\hline 576 & $t=0$ & 38337 & 1122637 & .50 & .05 & $\therefore 05$ & .100 & 100 & is & 30 \\
\hline 575 & $t \rightarrow 0$ & 392327 & 1112056 & 1.00 & .10 & .05 & .200 & 200 & $<.5$ & so \\
\hline 570 & $1=\pi$ & 3823 is & 11210 & 1.00 & .10 & .10 & .10ก & 300 & $\therefore 5$ & 70 \\
\hline 577 & $i=0$ & $18 \geqslant 4$ & $112 \geqslant 32$ & 1.00 & $\therefore 0$ & .10 & $\because 70$ & 500 & $\therefore 5$ & so \\
\hline 578 & $\ln 0$ & $3923 \quad 8$ & 1122812 & .50 & .05 & $\therefore .0 s$ & $\therefore 100$ & 150 & $\therefore 5$ & so \\
\hline 570 & 100 & 392311 & $112 \geqslant 30$ & .50 & .05 & $<.05$ & .usn & 300 & .5 & 20 \\
\hline $\sin$ & tot & 372318 & 11,2930 & 1.00 & .10 & .20 & .100 & 300 & s & so \\
\hline 581 & is & $3821<3$ & 1123131 & 10.00 & 3.00 & 5.00 & 1.000 & 700 & .5 & 1.000 \\
\hline SA2 & ib & $3822 ?$ & 1123026 & 1.00 & 1.00 & .10 & 1.000 & 150 & 5.0 & 1.000 \\
\hline 583 & $1 \mathrm{~b}$ & 382156 & 1123068 & 1.00 & .50 & .20 & .500 & 200 & $<.5$ & soo \\
\hline 986 & 10 & 382153 & 1123236 & 5.00 & 5.00 & 3.00 & 1.000 & 700 & $<s$ & $2.0 \mathrm{co}$ \\
\hline SAS & $m$ & 33720 & 11,3268 & .50 & $.0 ?$ & $.0 !$ & .1no & so & .5 & 200 \\
\hline 586 & 10 & 38226 & 1123246 & .50 & .10 & .20 & $\because 00$ & 500 & $\therefore 3$ & 300 \\
\hline SA ? & in & $3 A 21<3$ & 1123266 & 1.00 & .50 & .10 & .200 & 300 & $<.5$ & 100 \\
\hline 588 & $t=t$ & $3822<0$ & 1123267 & 10.00 & 3.00 & 5.00 & 1.000 & 700 & $\ddot{n}$ & 1.500 \\
\hline 580 & 10 & 382223 & 1123158 & .50 & .05 & .05 & .100 & 200 & $<.5$ & 30 \\
\hline 520 & to & $34>53$ & 1123132 & 10.00 & 3.00 & 7.00 & 1.000 & 1.000 & $\mathrm{~N}$ & 1,500 \\
\hline sor & $\tan$ & $38 \geqslant 2: 0$ & "113 & 2.00 & $1.0 n$ & .30 & .500 & 700 & c.5 & 500 \\
\hline 502 & $i=0$ & $B \geqslant 27$ & 1123360 & 1.00 & .10 & .10 & .200 & 2.000 & $<.5$ & 10 \\
\hline 503 & 10 & $3822 \quad 8$ & 1123333 & 10.00 & 5.00 & 5.00 & 1.000 & 700 & $\therefore s$ & 2.000 \\
\hline 506 & $\mathrm{tb}$ & 18,223 & 1123350 & 5.00 & 5.00 & 5.00 & 1.000 & 7 no & <.s & 2.000 \\
\hline 505 & 10 & $3 p 2351$ & 112360 & 2.00 & , no & 2.00 & 1.070 & son & $c .5$ & 2.000 \\
\hline 500 & to & 382365 & 1123560 & 2.00 & $\therefore .00$ & 2.00 & $\because .000$ & 700 & $\ddot{q}^{3}$ & 2,000 \\
\hline 507 & to & 34234 & 1123356 & 2.00 & 1.00 & .10 & .500 & 200 & .7 & 1.000 \\
\hline $5=8$ & to & $38>60$ &, 12367 & 2.00 & 1.00 & .20 & .500 & 200 & $\ddot{n}$ & 2.000 \\
\hline 500 & it & 382620 & 1123356 & .50 & $<02$ & .20 & .500 & $<10$ & $n$ & 1.000 \\
\hline 600. & Jps & $3 x \geq 43$ & 112363 & 1.00 & .10 & .20 & .100 & 200 & c.5 & 100 \\
\hline 601 & is & 182666 & 1123349 & 1.00 & .02 & .20 & .500 & 20 & $<, 5$ & 2.000 \\
\hline$\triangle \cap 2$ & $\mathrm{tb}$ & 382551 & 112 is 21 & .20 & 2.02 & .05 & .300 & 10 & $\ddot{n}$ & 200 \\
\hline 803 & it & 38 28 45 & 112362 & 10.00 & 5.00 & 5.00 & 1.000 & 1,000 & $\ddot{n}$ & 1,500 \\
\hline 606 & $0 \mathrm{tz}$ & $3826 \quad 66$ & 1123633 & .so & .10 & .10 & .010 & 200 & 1.0 & 200 \\
\hline
\end{tabular}




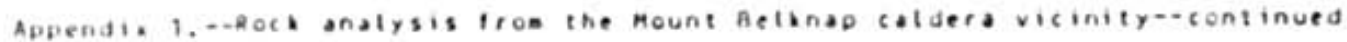

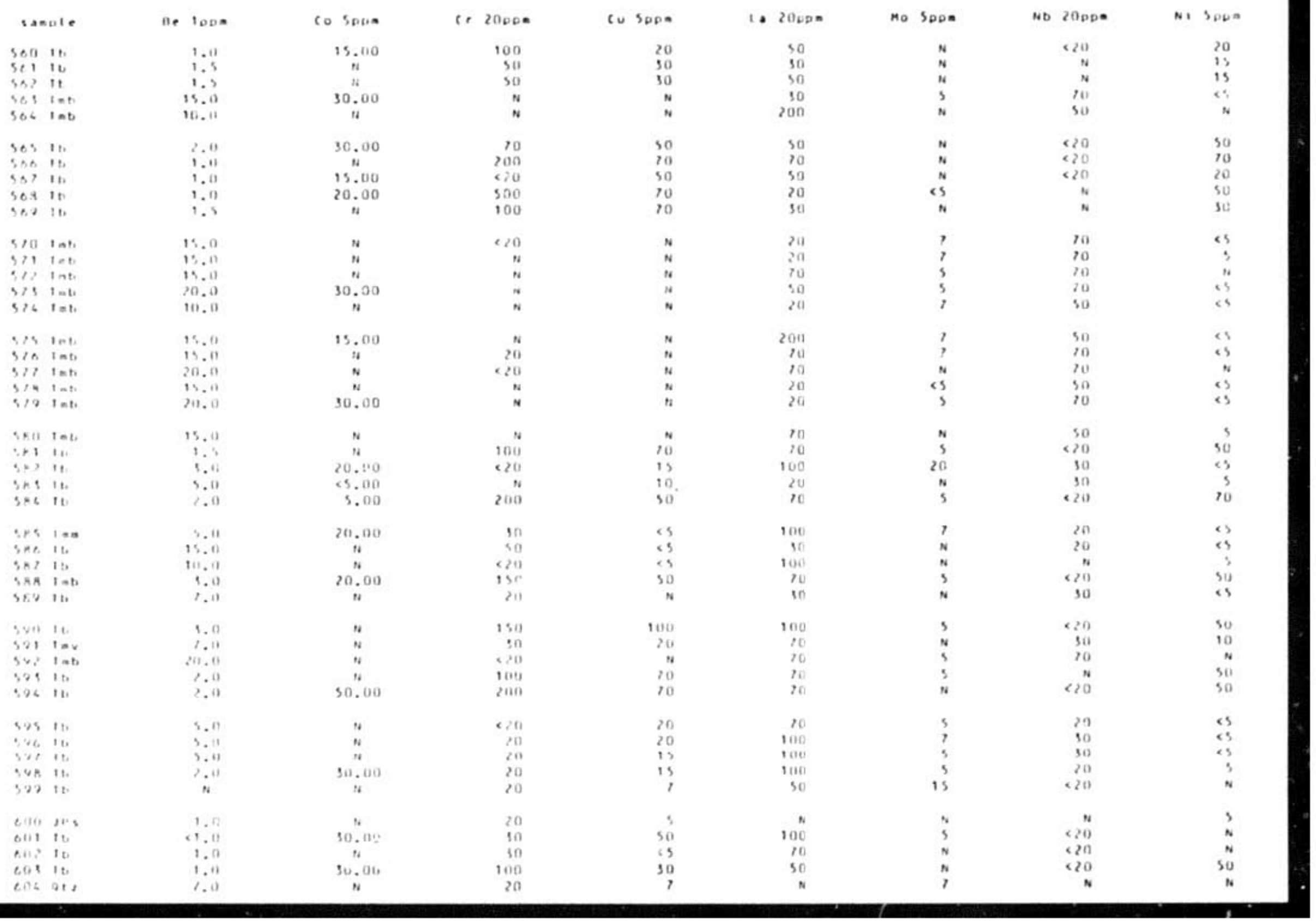




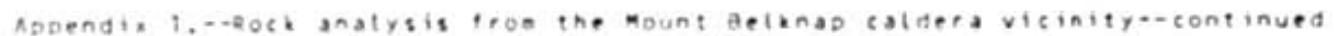

\begin{tabular}{|c|c|c|c|c|c|c|c|}
\hline wate & Do 1700 . & se 1000 & SETMDDE & $v 20000$ & , lopon & $209000=$ & G. 10000 \\
\hline 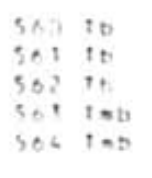 & $\begin{array}{l}30 \\
35 \\
30 \\
30 \\
70\end{array}$ & $\begin{array}{r}N \\
n \\
n \\
4 \\
\times 10\end{array}$ & $\begin{array}{r}50 \\
500 \\
700 \\
\times 00\end{array}$ & $\begin{array}{r}150 \\
3 \\
150 \\
150\end{array}$ & $\begin{array}{l}30 \\
20 \\
30 \\
15 \\
10\end{array}$ & $\begin{array}{l}200 \\
100 \\
200 \\
100 \\
500\end{array}$ & $\begin{array}{l}30 \\
20 \\
30 \\
20 \\
30\end{array}$ \\
\hline $\begin{array}{ll}505 & 18 \\
306 & 10 \\
302 & 10 \\
50 & 0 \\
500 & 10\end{array}$ & $\begin{array}{l}20 \\
30 \\
30 \\
15 \\
20\end{array}$ & $\begin{array}{l}n \\
n \\
\vdots \\
n\end{array}$ & $\begin{array}{r}500 \\
\because .000 \\
7000 \\
700 \\
700\end{array}$ & $\begin{array}{r}20 . \\
50 \\
200 \\
*\end{array}$ & $\begin{array}{l}30 \\
70 \\
30 \\
30 \\
10\end{array}$ & $\begin{array}{l}100 \\
200 \\
200 \\
200 \\
200\end{array}$ & $\begin{array}{l}20 \\
30 \\
50 \\
30 \\
30\end{array}$ \\
\hline 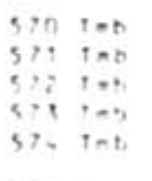 & $\begin{array}{l}20 \\
30 \\
50 \\
50 \\
30\end{array}$ & 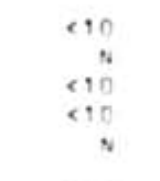 & $\begin{array}{l}n \\
\vdots \\
\vdots \\
\vdots \\
n\end{array}$ & $\begin{array}{r}8 \\
\vdots \\
307 \\
y\end{array}$ & $\begin{array}{l}20 \\
20 \\
50 \\
13 \\
20\end{array}$ & $\begin{array}{l}200 \\
200 \\
800 \\
200 \\
200\end{array}$ & $\begin{array}{l}30 \\
20 \\
30 \\
30 \\
20\end{array}$ \\
\hline 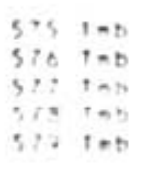 & $\begin{array}{l}30 \\
50 \\
30 \\
30 \\
30\end{array}$ & $\begin{array}{r}10 \\
110 \\
40 \\
8 \\
n\end{array}$ & $\begin{array}{l}v \\
\vdots \\
y \\
z\end{array}$ & $\begin{array}{r}200 \\
30 \\
n \\
500 \\
500\end{array}$ & $\begin{array}{l}70 \\
50 \\
50 \\
90 \\
20\end{array}$ & $\begin{array}{l}200 \\
200 \\
300 \\
200 \\
200\end{array}$ & $\begin{array}{c}30 \\
30 \\
30 \\
30 \\
20 \\
20\end{array}$ \\
\hline 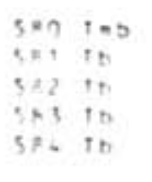 & $\begin{array}{l}30 \\
5 n \\
50 \\
30 \\
10\end{array}$ & $\begin{array}{l}n \\
n \\
n \\
n \\
n\end{array}$ & $\begin{array}{r}n \\
1.000 \\
150 \\
100 \\
100\end{array}$ & $\begin{array}{r}n \\
200 \\
100 \\
100\end{array}$ & $\begin{array}{l}30 \\
10 \\
50 \\
20 \\
30\end{array}$ & $\begin{array}{l}200 \\
200 \\
500 \\
500 \\
200\end{array}$ & $\begin{array}{l}20 \\
30 \\
10 \\
15 \\
30\end{array}$ \\
\hline 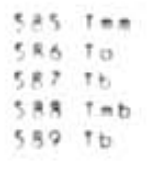 & $\begin{array}{l}20 \\
30 \\
20 \\
50 \\
30\end{array}$ & $\begin{array}{l}N \\
v \\
\vdots \\
\vdots\end{array}$ & 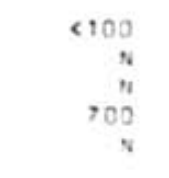 & $\begin{array}{r}200 \\
n \\
200 \\
n \\
n\end{array}$ & $\begin{array}{l}15 \\
15 \\
50 \\
30 \\
10\end{array}$ & $\begin{array}{l}200 \\
100 \\
200 \\
200 \\
150\end{array}$ & $\begin{array}{l}15 \\
20 \\
30 \\
30 \\
30\end{array}$ \\
\hline 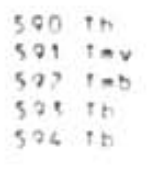 & $\begin{array}{l}30 \\
70 \\
70 \\
30 \\
50\end{array}$ & $\stackrel{8}{8}$ & $\begin{array}{r}500 \\
<100 \\
n \\
1.070 \\
707\end{array}$ & \begin{tabular}{r}
\multirow{N}{N}{} \\
200 \\
20
\end{tabular} & $\begin{array}{l}30 \\
30 \\
50 \\
30 \\
30\end{array}$ & $\begin{array}{l}700 \\
200 \\
200 \\
200 \\
200\end{array}$ & $\begin{array}{l}50 \\
30 \\
50 \\
30 \\
30\end{array}$ \\
\hline 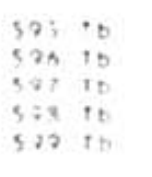 & $\begin{array}{c}30 \\
30 \\
30 \\
15 \\
103\end{array}$ & $\begin{array}{l}\Delta \\
0 \\
n \\
n\end{array}$ & $\begin{array}{r}500 \\
1.000 \\
900 \\
100 \\
700\end{array}$ & $\begin{array}{r}n \\
n \\
200 \\
*\end{array}$ & $\begin{array}{r}20 \\
30 \\
30 \\
30 \\
30\end{array}$ & $\begin{array}{l}100 \\
500 \\
200 \\
200 \\
200\end{array}$ & $\begin{array}{l}30 \\
50 \\
30 \\
30 \\
50\end{array}$ \\
\hline 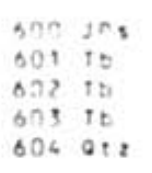 & $\begin{array}{l}20 \\
70 \\
15 \\
50 \\
v\end{array}$ & $\begin{array}{l}n \\
n \\
u \\
u \\
n\end{array}$ & $\begin{array}{r}n \\
1.000 \\
200 \\
1.000 \\
100\end{array}$ & $\begin{array}{l}203 \\
200 \\
N\end{array}$ & $\begin{array}{r}N \\
30 \\
20 \\
30 \\
<10\end{array}$ & $\begin{array}{l}200 \\
200 \\
200 \\
200 \\
100\end{array}$ & $\begin{array}{l}N \\
50 \\
15 \\
30 \\
N\end{array}$ \\
\hline
\end{tabular}




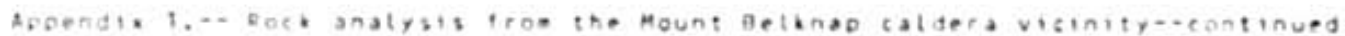

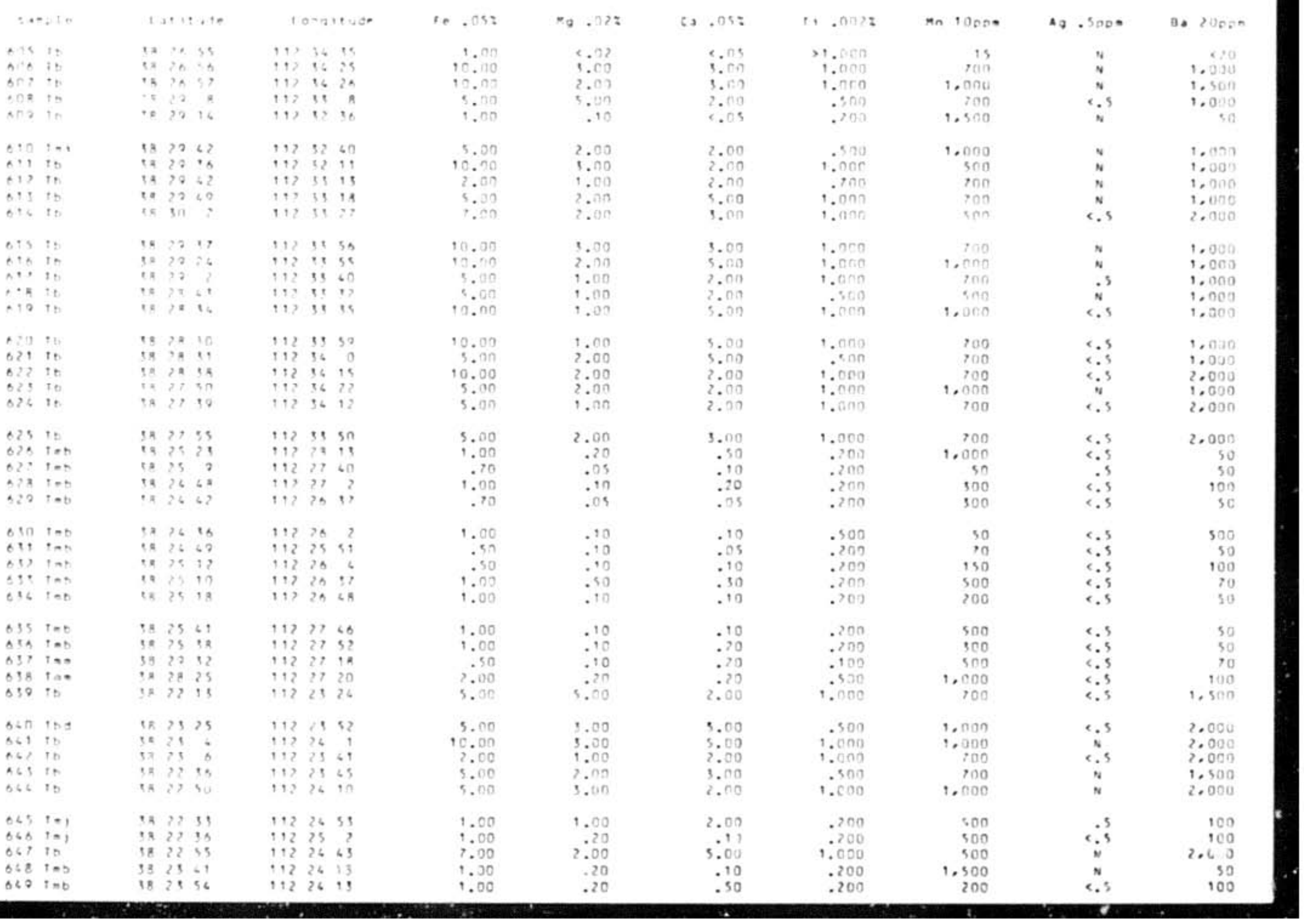




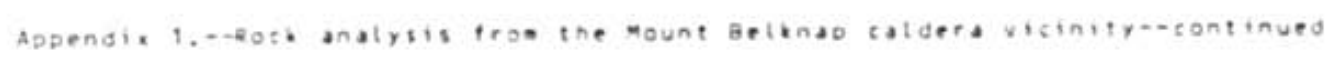

\begin{tabular}{|c|c|c|c|c|c|c|c|c|}
\hline sante & e. 1000 & $605=0 \%$ & $c=20000$ & Cu soon & $t=2000=$ & No So00 & No $2000=$ & $N, 500=$ \\
\hline ons is & «. & 30.00 & so & 35 & $s$ & $\mathrm{~N}$ & $<20$ & N \\
\hline$O C A T B$ & 1.5 & $v$ & 100 & 20 & 70 & N & $N$ & 56 \\
\hline 007 to & 1.5 & 4 & 100 & 50 & n & v & $<20$ & 50 \\
\hline 608 ib & 2.7 & 15.00 & 50 & 30 & So & $v$ & $<20$ & 20 \\
\hline 00010 & 15.7 & 20.00 & $n$ & $v$ & ;0 & cs & so & \&s \\
\hline $\begin{array}{ll}010 & 101 \\
011 & 10\end{array}$ & 1.5 & v & 30 & 30 & 50 & $n$ & $\mathrm{~N}$ & 20 \\
\hline $\begin{array}{ll}011 & 10 \\
017 & 10\end{array}$ & 1.0 & $\mathrm{~s}$ & 10 & 50 & so & N & $<20$ & 30 \\
\hline $\begin{array}{lll}0: ? & 10 \\
011 & 10\end{array}$ & 1.5 & N & 50 & 90 & 50 & $v$ & N & 15 \\
\hline $\begin{array}{lll}011 & 10 \\
0 & 10 & \text { to }\end{array}$ & 1.5 & 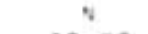 & 50 & 20 & 50 & N & $*$ & 20 \\
\hline $01+10$ & $2 \cdot n$ & 10.00 & 100 & 10 & 10 & s & $<20$ & 20 \\
\hline $\begin{array}{ll}019 & 10 \\
510 & \text { to }\end{array}$ & 1.5 & 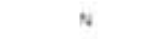 & 50 & 30 & 50 & $\mathrm{~N}$ & $<20$ & 50 \\
\hline $\begin{array}{ll}510 & \text { to } \\
01 & \text { is }\end{array}$ & 7.7 & $n$ & $10 \%$ & 50 & 70 & N & $<20$ & so \\
\hline $\begin{array}{lll}010 & \text { is } \\
0 & 13 & \text { is }\end{array}$ & $? . ?$ & n & 70 & 50 & 80 & N & 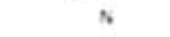 & 20 \\
\hline $\begin{array}{ll}013 & 10 \\
012 & 10\end{array}$ & 1.8 & $s$ & 30 & 20 & 30 & $n$ & $\mathrm{~s}$ & is \\
\hline 012 to & 7.0 & $N$ & 100 & 30 & 57 & N & $<20$ & 90 \\
\hline $\begin{array}{ll}0 & ? 0 \\
0 ? & 10\end{array}$ & 1.5 & 30.00 & 50 & 30 & 20 & $*$ & $N$ & 20 \\
\hline $\begin{array}{ll}0 ? \\
0 \geqslant \geqslant 10\end{array}$ & $\therefore 0$ & $\mathrm{~N}$ & 100 & 100 & 10 & 4 & $<20$ & 20 \\
\hline $\begin{array}{l}6 \geqslant 210 \\
0 \geqslant 310\end{array}$ & 1.5 & $\mathrm{~s}$ & 70 & 90 & 50 & $n$ & $<20$ & 20 \\
\hline $\begin{array}{ll}623 & 10 \\
624 & 10\end{array}$ & $\because{ }^{2}$ & 20.00 & ion & 50 & 10 & N & $<20$ & so \\
\hline $6: 2415$ & 1.0 & $\mathrm{~s}$ & $<\geqslant 0$ & 50 & 100 & 90 & 10 & 5 \\
\hline $\begin{array}{ll}A>5 & t b \\
0>0 & \text { ta }\end{array}$ & 7.0 & 20.00 & 50 & so & 70 & v & $<20$ & 50 \\
\hline $\begin{array}{lll}0 \geqslant 0 & t \rightarrow b \\
c \geqslant & t \rightarrow 0\end{array}$ & 15.0 & $\mathrm{~N}$ & 30 & v & 50 & s & 70 & $v$ \\
\hline 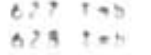 & 15.0 & 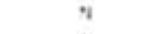 & e? & $N$ & 70 & N & 50 & $N$ \\
\hline 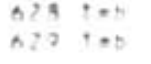 & 18.0 & $n$ & $<20$ & $v$ & N & 5 & 50 & s \\
\hline$A \geq 2+0 B$ & 15.0 & 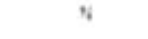 & 20 & N & $s$ & 5 & 50 & v \\
\hline 650100 & 5.0 & 15.00 & $<20$ & 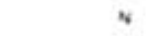 & 70 & 5 & 70 & <s \\
\hline 039105 & 1.0 & 20.00 & $<20$ & N & ?u & <s & 70 & $s$ \\
\hline $0 ? ? \quad T=b$ & 30.0 & 30.00 & $<20$ & es & 50 & $N$ & 50 & (s) \\
\hline 835 in & $\because \because 0$ & 20.00 & $<20$ & cs & 50 & s & 70 & Cs \\
\hline $018: 07$ & 15.0 & $5 \pi .00$ & $v$ & 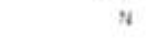 & 300 & 7 & 50 & cs \\
\hline sis ios & 15.0 & 15.00 & N & $v$ & 30 & , & 50 & cs \\
\hline 0,5105 & 20.7 & 10.00 & $<0$ & $\sim$ & 20 & $<5$ & 10 & r \\
\hline 037100 & 10.7 & $v$ & N & $s$ & 5 & 10 & 50 & es \\
\hline A35 10. & 20.0 & 30.00 & $2 \pi$ & $<5$ & 100 & \&s & 70 & es \\
\hline 35010 & 9.0 & v & 100 & 50 & 50 & $*$ & $<20$ & 50 \\
\hline 860 t+a & 1.0 & 20.00 & סרים & sn & 70 & $n$ & $<20$ & 30 \\
\hline 047 is & 2.0 & 5.00 & 200 & 70 & 100 & s & $<20$ & 50 \\
\hline 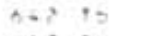 & $? .0$ & $n$ & $n$ & 15 & 10 & s & $<20$ & es \\
\hline 06510 & 1.0 & 50.00 & 200 & 50 & 50 & v & $<20$ & so \\
\hline 06610 & 1.5 & $v$ & iso & 50 & o & cs & $<20$ & 50 \\
\hline $065+2.3$ & 20.0 & 4 & $n$ & cs & 30 & N & 50 & $v$ \\
\hline $0,5 \quad:=1$ & 20 & $v$ & 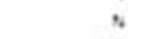 & es & 10 & 7 & 30 & cs \\
\hline 36710 & 2.0 & 90.00 & 10 & 70 & 50 & 3 & $<>0$ & 20 \\
\hline$a-8 \quad t a b$ & 10.0 & 30.00 & $\mathrm{~s}$ & $N$ & 10 & N & 70 & $\mathrm{~N}$ \\
\hline $0<2$ iab & 7.0 & $n$ & $N$ & cs & so & n & 50 & $s$ \\
\hline
\end{tabular}


Abpendix 1.- Rock anstysis fros the Mount Betbas esldeco vitinityo-continued

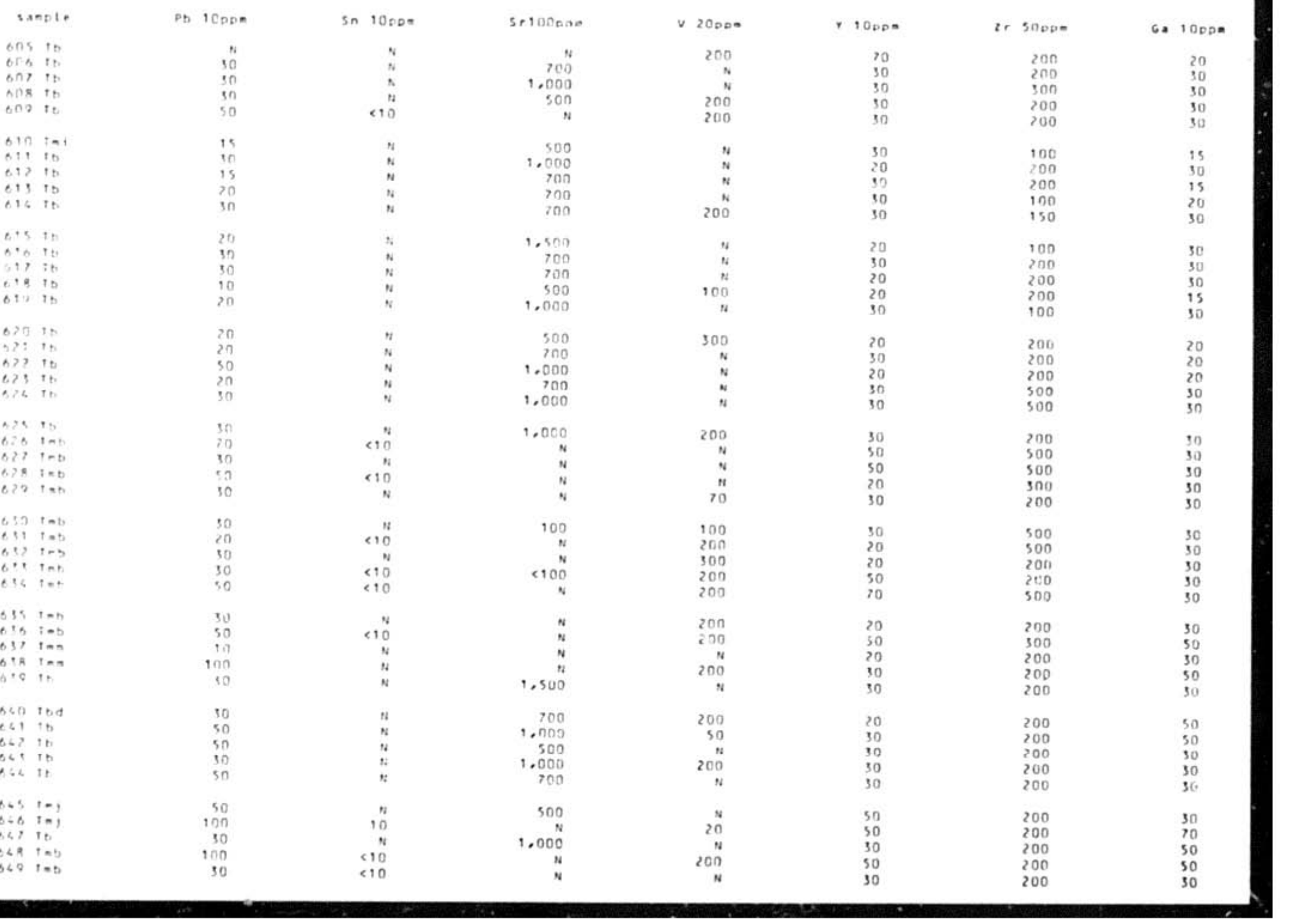




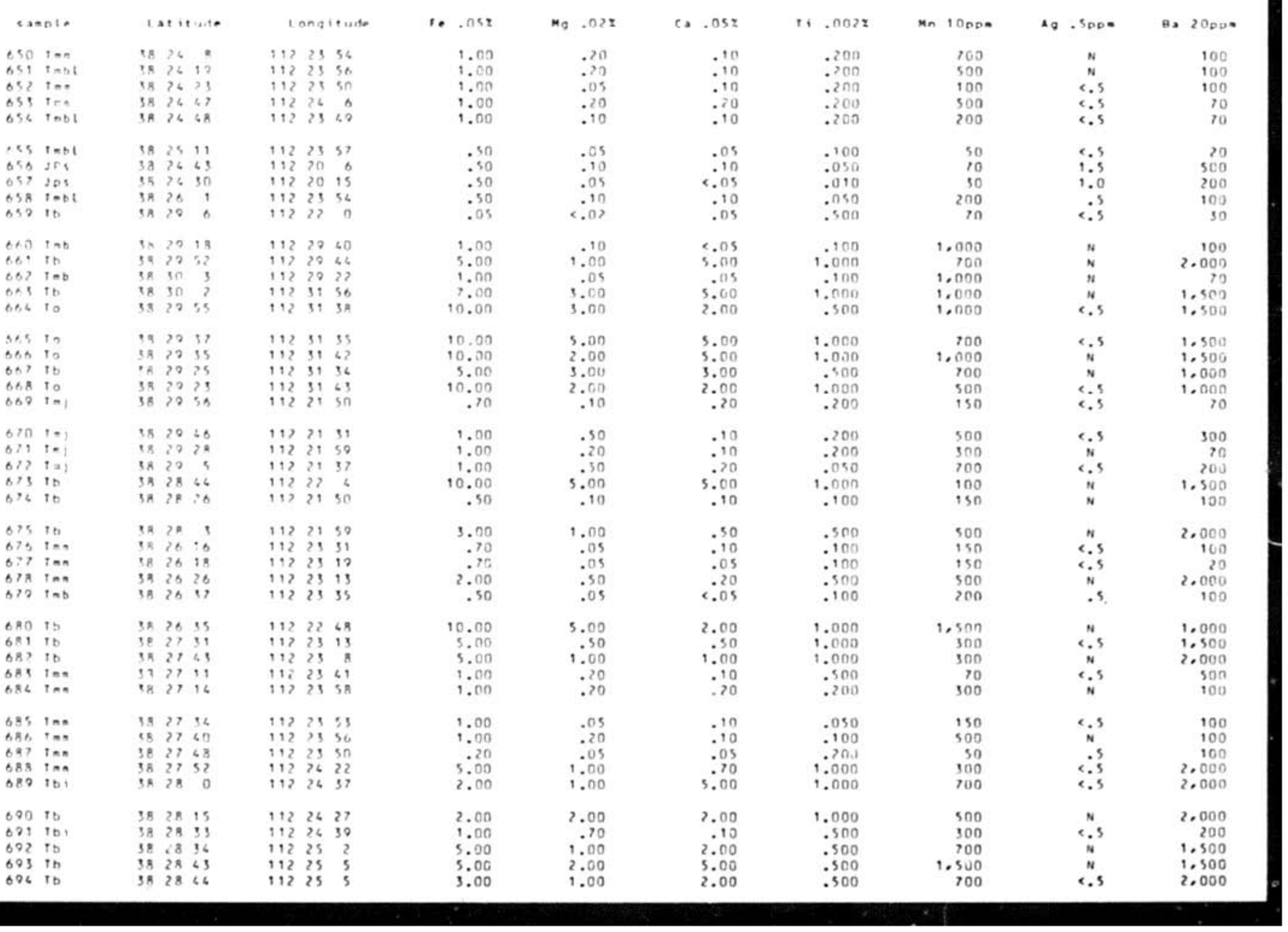


Appendis 1.- Rock anatysis from the Mount Delknap caldera vicinityacontinued

\begin{tabular}{|c|c|c|c|c|c|c|c|c|c|}
\hline \multicolumn{2}{|c|}{ sente } & Be 1500 & co soon & 6,20000 & cu sppn & L. $20 \mathrm{pD}=$ & MO SDDO & NB $20 D D=$ & $N$ S SOD \\
\hline 650 & $t \mathrm{~mm}$ & 10.0 & 20.00 & $n$ & $<5$ & 30 & $N$ & 50 & cs \\
\hline 651 & $|a b|$ & 7.0 & $n$ & $<20$ & $<5$ & 70 & 10 & 70 & es \\
\hline 852 & $t m$ & 20.0 & 15.00 & 20 & 5 & 70 & $n$ & 50 & <s \\
\hline 653 & $\operatorname{lnn}$ & 10.0 & N & $N$ & cs & 30 & $n$ & 50 & es \\
\hline 6.54 & $t \rightarrow b t$ & 3.0 & 30.00 & $<20$ & $n$ & 50 & es & 70 & $N$ \\
\hline 655 & $t=b t$ & 1.0 & $n$ & $n$ & $v$ & 50 & $N$ & 70 & $n$ \\
\hline 650 & JPs & 1.0 & 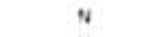 & 20 & 10 & $N$ & 10 & $n$ & N \\
\hline 657 & Jos & 1.0 & $N$ & 20 & $s$ & $\mathrm{~N}$ & is & $n$ & $n$ \\
\hline 658 & $1=01$ & 5.0 & 7.00 & $n$ & $N$ & 20 & $n$ & so & cs \\
\hline 650 & ib & 5.0 & $N$ & $<20$ & $<5$ & 100 & \&s & 70 & $n$ \\
\hline $6 \times 0$ & 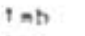 & 20.0 & $n$ & $<2 n$ & $<5$ & 10 & 15 & 70 & <s \\
\hline 661 & is & 3.0 & $v$ & 20 & 20 & 100 & 5 & 20 & $<5$ \\
\hline 667 & $i \sim b$ & 15.0 & 30.00 & $<\geqslant 0$ & $n$ & 10 & is & 20 & <s \\
\hline 605 & is & 1.0 & $v$ & 70 & 50 & 50 & $n$ & $\mathrm{~s}$ & 20 \\
\hline 506 & 10 & 1.8 & 5.00 & 100 & 50 & 50 & N & $<20$ & 30 \\
\hline 605 & 10 & 1.0 & $"$ & 10 & 50 & 50 & N & $<20$ & 20 \\
\hline Be. & 10 & 1.5 & $n$ & 150 & 30 & 70 & $n$ & $n$ & 20 \\
\hline 867 & it & 2.0 & 30.00 & so & 30 & 30 & <s & n & 20 \\
\hline $08 \pi$ & 10 & ๆ. 0 & $n$ & 50 & 30 & 50 & $N$ & $<\geqslant 0$ & 20 \\
\hline 062 & $1=1$ & 20.0 & $v$ & 30 & 5 & 70 & 5 & so & <s \\
\hline $67 n$ & 101 & 20.0 & 30.00 & 20 & 7 & 70 & $n$ & 50 & 5 \\
\hline$\alpha>1$ & $1=i$ & 15.0 & 30.00 & $<20$ & $n$ & so & $N$ & 10 & $n$ \\
\hline 677 & $t=i$ & 20.0 & v & $N$ & 5 & סו & $n$ & 30 & es \\
\hline 673 & $1 \mathrm{a}$ & 1.5 & 30.00 & 300 & 70 & 50 & N & $<20$ & 70 \\
\hline 876 & it & 15.0 & 30.00 & $<20$ & es & 30 & N & 30 & 5 \\
\hline 675 & it & 7.0 & $n$ & 30 & so & 100 & 5 & 50 & 7 \\
\hline B $7 \mathrm{~A}$ & $\tan$ & 10.0 & $v$ & $n$ & $n$ & 70 & $n$ & so & <s \\
\hline $8 \geqslant 7$ & $T a$ & 7.0 & $v$ & $\omega$ & $N$ & 30 & $n$ & 70 & cs \\
\hline 679 & $T=n$ & 5.0 & $n$ & $<>0$ & \&s & 150 & N & 30 & $n$ \\
\hline 670 & $t=n$ & $? 0$ & $\mathrm{~s}$ & $<20$ & $N$ & $<20$ & N & 50 & cs \\
\hline 680 & Tt & 2.0 & 30.00 & 300 & 70 & 70 & N & $<20$ & 70 \\
\hline 681 & is & 7.0 & 10.00 & 70 & 20 & 0 & 7 & 30 & is \\
\hline BB? & it & 5.0 & 30.00 & 30 & 20 & 10 & 7 & 30 & 10 \\
\hline 693 & $\tan$ & 10.0 & 50.00 & 50 & 7 & 13.3 & $N$ & 50 & cs \\
\hline 686 & $\tan$ & 7.0 & 30.00 & $<20$ & 5 & 70 & $N$ & 30 & \&s \\
\hline CBS & $t=0$ & ? $n$ & $*$ & $n$ & cs & 70 & N & 30 & cs \\
\hline 636 & 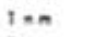 & 15.0 & $20 . \cap 0$ & $<20$ & 5 & 70 & $N$ & 30 & \&s \\
\hline$B A 7$ & $T=n$ & 3.0 & in & $<>0$ & $<5$ & 100 & N & so & es \\
\hline 688 & $T n$ & 5.0 & 4 & 20 & 20 & 100 & $N$ & 30 & es \\
\hline 680 & 101 & 3.0 & 10.00 & 50 & 30 & 100 & 7 & 30 & 5 \\
\hline 600 & is & 5.0 & 15.00 & 20 & 20 & 70 & n & 20 & 5 \\
\hline 609 & 101 & in. $n$ & 13.00 & $<20$ & 7 & 70 & $n$ & 20 & <s \\
\hline 607 & 10 & 2.0 & s & $<20$ & 20 & 50 & $N$ & $<20$ & cs \\
\hline 695 & 10 & 3.0 & 20.00 & 30 & 20 & 70 & N & $<20$ & 7 \\
\hline 626 & 10 & 1.5 & 20.00 & 30 & 20 & 50 & $N$ & $<20$ & es \\
\hline
\end{tabular}




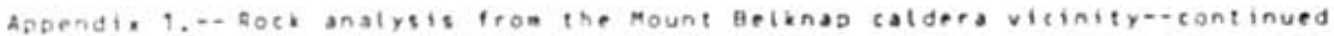

\begin{tabular}{|c|c|c|c|c|c|c|c|}
\hline sonte & PD $10 \mathrm{DD}$. & Sn 1000 . & SF100DDn & $\checkmark 20000$ & r 10000 & If SODDO & GA 10DDE \\
\hline 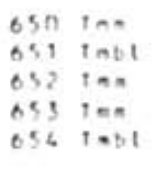 & $\begin{array}{r}20 \\
20 \\
30 \\
40 \\
15\end{array}$ & 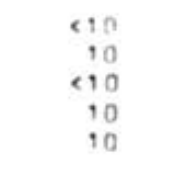 & $\begin{array}{l}n \\
n \\
n \\
n \\
n\end{array}$ & $\begin{array}{r}200 \\
n \\
200 \\
n \\
200\end{array}$ & $\begin{array}{l}30 \\
50 \\
30 \\
30 \\
30\end{array}$ & $\begin{array}{l}150 \\
200 \\
200 \\
200 \\
200\end{array}$ & $\begin{array}{l}30 \\
50 \\
30 \\
50 \\
50\end{array}$ \\
\hline 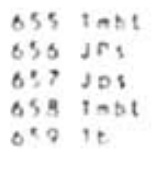 & $\begin{array}{l}30 \\
30 \\
50 \\
10 \\
\text { in }\end{array}$ & 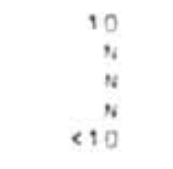 & $\begin{array}{r}n \\
n \\
n \\
300 \\
<100\end{array}$ & $\begin{array}{r}N \\
n \\
200 \\
100 \\
N\end{array}$ & $\begin{array}{r}10 \\
10 \\
20 \\
20 \\
30\end{array}$ & $\begin{array}{l}300 \\
200 \\
200 \\
200 \\
200\end{array}$ & $\begin{array}{r}30 \\
n \\
n \\
20 \\
20\end{array}$ \\
\hline 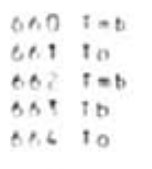 & $\begin{array}{l}30 \\
30 \\
30 \\
0 \\
n\end{array}$ & $\begin{array}{r}r a \\
N \\
\times 10 \\
N\end{array}$ & $\begin{array}{c}50 \\
n \\
n \\
700 \\
300\end{array}$ & $\begin{array}{r}70 \\
2 n \pi \\
n \\
70 \\
70\end{array}$ & $\begin{array}{l}30 \\
30 \\
30 \\
30 \\
10\end{array}$ & $\begin{array}{l}300 \\
200 \\
200 \\
100 \\
200\end{array}$ & $\begin{array}{l}50 \\
50 \\
30 \\
30 \\
30\end{array}$ \\
\hline 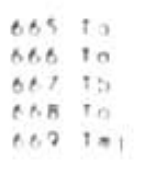 & $\begin{array}{l}30 \\
30 \\
20 \\
30 \\
00\end{array}$ & $\begin{array}{l}n \\
n \\
n \\
n\end{array}$ & $\begin{array}{c}700 \\
700 \\
500 \\
700 \\
" 1\end{array}$ & $\begin{array}{r}n \\
n \\
500 \\
n \\
" ~\end{array}$ & $\begin{array}{l}20 \\
30 \\
20 \\
30 \\
20\end{array}$ & $\begin{array}{l}150 \\
150 \\
100 \\
100 \\
100\end{array}$ & $\begin{array}{l}30 \\
30 \\
20 \\
30 \\
30\end{array}$ \\
\hline 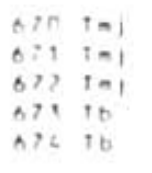 & $\begin{array}{l}37 \\
313 \\
50 \\
30 \\
30\end{array}$ & $\begin{array}{r}10 \\
10 \\
410 \\
N \\
N\end{array}$ & $\begin{array}{r}100 \\
10 \\
100 \\
1.000 \\
8100\end{array}$ & $\begin{array}{r}200 \\
300 \\
10 \\
200 \\
200\end{array}$ & $\begin{array}{l}70 \\
30 \\
50 \\
30 \\
15\end{array}$ & $\begin{array}{l}200 \\
100 \\
200 \\
300 \\
200\end{array}$ & $\begin{array}{l}20 \\
20 \\
20 \\
30 \\
15\end{array}$ \\
\hline 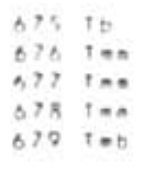 & $\begin{array}{l}10 \\
30 \\
10 \\
70 \\
20\end{array}$ & 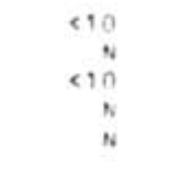 & $\begin{array}{r}500 \\
r 100 \\
n \\
20 n \\
n\end{array}$ & $\begin{array}{l}n \\
N \\
n \\
n \\
N\end{array}$ & $\begin{array}{l}30 \\
20 \\
30 \\
50 \\
20\end{array}$ & $\begin{array}{l}500 \\
200 \\
200 \\
300 \\
200\end{array}$ & $\begin{array}{l}30 \\
30 \\
10 \\
20 \\
13 \\
30\end{array}$ \\
\hline 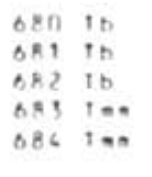 & $\begin{array}{l}20 \\
76 \\
50 \\
30 \\
30\end{array}$ & $\begin{array}{l}n \\
n \\
n \\
n \\
n\end{array}$ & $\begin{array}{r}r, 000 \\
5 n 0 \\
500 \\
100 \\
400\end{array}$ & $\begin{array}{r}200 \\
N \\
200 \\
300 \\
100\end{array}$ & $\begin{array}{r}30 \\
30 \\
30 \\
100 \\
20\end{array}$ & $\begin{array}{l}200 \\
700 \\
200 \\
300 \\
200\end{array}$ & $\begin{array}{l}30 \\
30 \\
30 \\
30 \\
30\end{array}$ \\
\hline 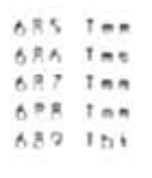 & $\begin{array}{l}5 n \\
3 n \\
30 \\
3 n \\
10\end{array}$ & $\begin{array}{l}n \\
n \\
n \\
n \\
n\end{array}$ & $\begin{array}{l}<100 \\
200 \\
400 \\
200 \\
700\end{array}$ & $\begin{array}{r}200 \\
700 \\
70 \\
50 \\
100\end{array}$ & $\begin{array}{l}20 \\
30 \\
20 \\
30 \\
30\end{array}$ & $\begin{array}{l}200 \\
100 \\
200 \\
200 \\
300\end{array}$ & $\begin{array}{l}30 \\
20 \\
30 \\
30 \\
30\end{array}$ \\
\hline 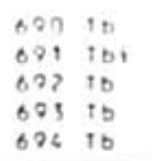 & $\begin{array}{l}0 \\
20 \\
20 \\
30 \\
20\end{array}$ & $\begin{array}{l}n \\
n \\
n \\
n\end{array}$ & $\begin{array}{l}700 \\
150 \\
500 \\
500 \\
500\end{array}$ & $\begin{array}{l}100 \\
100 \\
200 \\
200 \\
200\end{array}$ & $\begin{array}{l}30 \\
30 \\
30 \\
30 \\
30\end{array}$ & $\begin{array}{l}200 \\
200 \\
200 \\
200 \\
200\end{array}$ & $\begin{array}{l}20 \\
15 \\
15 \\
20 \\
20\end{array}$ \\
\hline
\end{tabular}




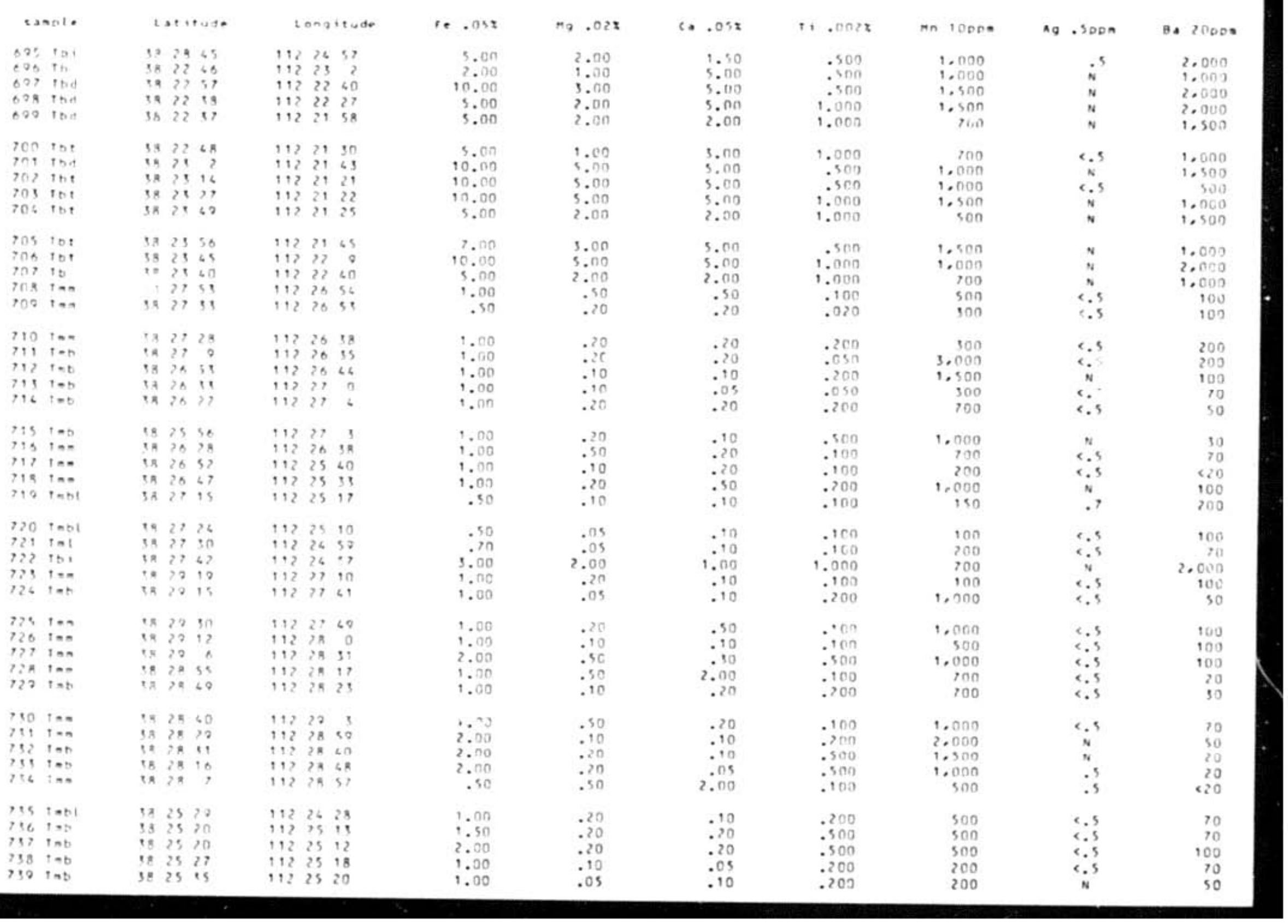




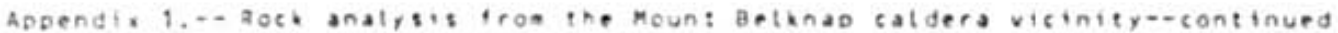

\begin{tabular}{|c|c|c|c|c|c|c|c|c|}
\hline wore & Ee 1000 & cossoon & $6+20000$ & co soon & LS 2000 " & MO SODE & No 20000 & N \\
\hline 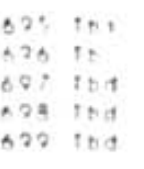 & $\begin{array}{l}\because 0 \\
2 \because n \\
\because \because 0 \\
20\end{array}$ & $\begin{array}{c}4 \\
8 \\
30.00 \\
7.00\end{array}$ & $\begin{array}{l}200 \\
200 \\
100 \\
20 \\
30\end{array}$ & $\begin{array}{l}30 \\
30 \\
30 \\
20 \\
15\end{array}$ & $\begin{array}{r}30 \\
50 \\
50 \\
100 \\
50\end{array}$ & $\begin{array}{l}n \\
4 \\
3 \\
3 \\
n\end{array}$ & $\begin{array}{r}<20 \\
220 \\
200 \\
200 \\
N\end{array}$ & $\begin{array}{l}35 \\
30 \\
30 \\
20\end{array}$ \\
\hline 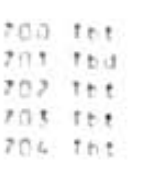 & $\begin{array}{l}\because \% \\
\because \because \\
\because \% \\
30 \\
2.0\end{array}$ & $\begin{array}{c}10.00 \\
\vdots \\
y \\
20.00\end{array}$ & $\begin{array}{l}100 \\
150 \\
200 \\
200 \\
150\end{array}$ & $\begin{array}{l}30 \\
30 \\
30 \\
70 \\
20\end{array}$ & $\begin{array}{l}20 \\
30 \\
50 \\
50 \\
30\end{array}$ & $\begin{array}{l}n \\
n \\
n \\
n\end{array}$ & $\begin{array}{l}<20 \\
20 \\
220 \\
220 \\
<20\end{array}$ & $\begin{array}{l}30 \\
30 \\
50 \\
50 \\
50\end{array}$ \\
\hline 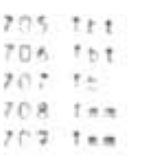 & $\begin{array}{r}\because 0 \\
\because \because 0 \\
\because 00 \\
10: 0\end{array}$ & $\begin{array}{c}15.00 \\
50: 00 \\
5 \\
50.00\end{array}$ & $\begin{array}{l}150 \\
200 \\
250 \\
20 \\
\times 20\end{array}$ & $\begin{array}{l}20 \\
50 \\
30 \\
10 \\
\text { is }\end{array}$ & $\begin{array}{r}50 \\
50 \\
50 \\
70 \\
700\end{array}$ & $\begin{array}{l}n \\
n \\
n \\
n\end{array}$ & $\begin{array}{l}<20 \\
30 \\
<20 \\
30 \\
30\end{array}$ & $\begin{array}{l}30 \\
50 \\
30 \\
35 \\
\$ 5 \\
35\end{array}$ \\
\hline 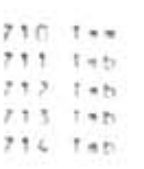 & $\begin{array}{l}20.0 \\
350 \\
50 \\
3 \%\end{array}$ & 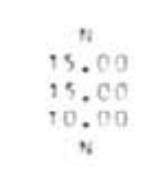 & $\therefore$ & is & $\begin{array}{l}50 \\
50 \\
30 \\
50 \\
50\end{array}$ & $\begin{array}{l}n \\
n \\
\vdots \\
\vdots\end{array}$ & $\begin{array}{l}70 \\
50 \\
70 \\
70 \\
70\end{array}$ & $\begin{array}{l}\text { \&s } \\
\text { \&s } \\
\text { is } \\
\text { is }\end{array}$ \\
\hline 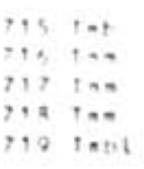 & $\begin{array}{c}3: 0 \\
0 \\
0 \\
0 \\
\vdots \\
30\end{array}$ & $\begin{array}{c}8 \\
30.00 \\
30.00\end{array}$ & $\begin{array}{c}8 \\
8 \\
20 \\
20 \\
20\end{array}$ & ss & $\begin{array}{l}70 \\
30 \\
50 \\
50 \\
50\end{array}$ & $\begin{array}{l}n \\
n \\
n \\
s\end{array}$ & $\begin{array}{l}70 \\
70 \\
50 \\
50 \\
30\end{array}$ & $\begin{array}{l}\text { is } \\
\text { is } \\
\text { is } \\
\text { is }\end{array}$ \\
\hline 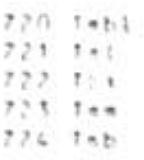 & $\begin{array}{r}\because 0 \\
\because \because 0 \\
150 \\
30.0\end{array}$ & $\begin{array}{c}5.00 \\
20.00 \\
20.00 \\
70.00\end{array}$ & $\begin{array}{r}r 0 \\
20 \\
<20 \\
\because 8\end{array}$ & $\begin{array}{l}35 \\
20 \\
20 \\
3 \\
3\end{array}$ & $\begin{array}{l}20 \\
10 \\
70 \\
70 \\
70\end{array}$ & $\begin{array}{c}3 \\
\vdots \\
5 \\
\text { is }\end{array}$ & $\begin{array}{l}50 \\
50 \\
30 \\
50 \\
10\end{array}$ & $\begin{array}{l}\text { is } \\
\text { is } \\
\text { is } \\
\text { is }\end{array}$ \\
\hline $\begin{array}{ll}m \\
\cdots \\
m \\
\cdots \\
\cdots\end{array}$ & 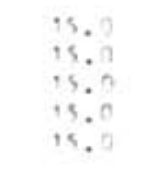 & 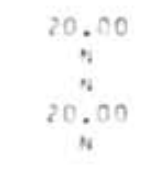 & $\begin{array}{r}<20 \\
220 \\
<20 \\
3 \\
4\end{array}$ & $\begin{array}{l}3 s \\
\text { is } \\
s \\
N \\
4\end{array}$ & $\begin{array}{l}70 \\
30 \\
50 \\
70 \\
70\end{array}$ & $\begin{array}{l}n \\
5 \\
5 \\
n\end{array}$ & $\begin{array}{l}50 \\
50 \\
70 \\
70 \\
50\end{array}$ & $\begin{array}{l}\text { is } \\
\text { is } \\
\text { is } \\
4\end{array}$ \\
\hline 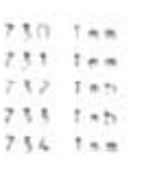 & $\begin{array}{l}20.0 \\
30 \\
30 \\
20\end{array}$ & $\begin{array}{c}30.00 \\
; \\
30.00 \\
15.00\end{array}$ & 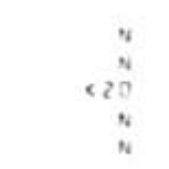 & $\begin{array}{l}3 \\
s \\
s \\
4 \\
s\end{array}$ & $\begin{array}{l}70 \\
70 \\
70 \\
30 \\
30\end{array}$ & $\stackrel{n}{3}$ & $\begin{array}{l}y_{0} \\
y_{0} \\
y_{0} \\
30\end{array}$ & 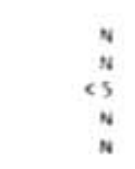 \\
\hline 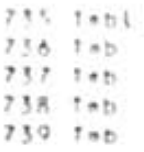 & $\begin{array}{l}15 \% \\
\vdots 0 \\
30 \\
0.0\end{array}$ & $\begin{array}{l}n \\
y \\
n \\
n \\
n\end{array}$ & $\begin{array}{r}<20 \\
<20 \\
<20 \\
*\end{array}$ & $\begin{array}{l}\mathrm{s} \\
\mathrm{n} \\
\mathrm{n} \\
\mathrm{n}\end{array}$ & $\begin{array}{r}20 \\
70 \\
100 \\
30 \\
30\end{array}$ & $\begin{array}{c}n \\
10 \\
10 \\
\vdots \\
3\end{array}$ & $\begin{array}{l}70 \\
50 \\
70 \\
70 \\
70\end{array}$ & ss \\
\hline
\end{tabular}




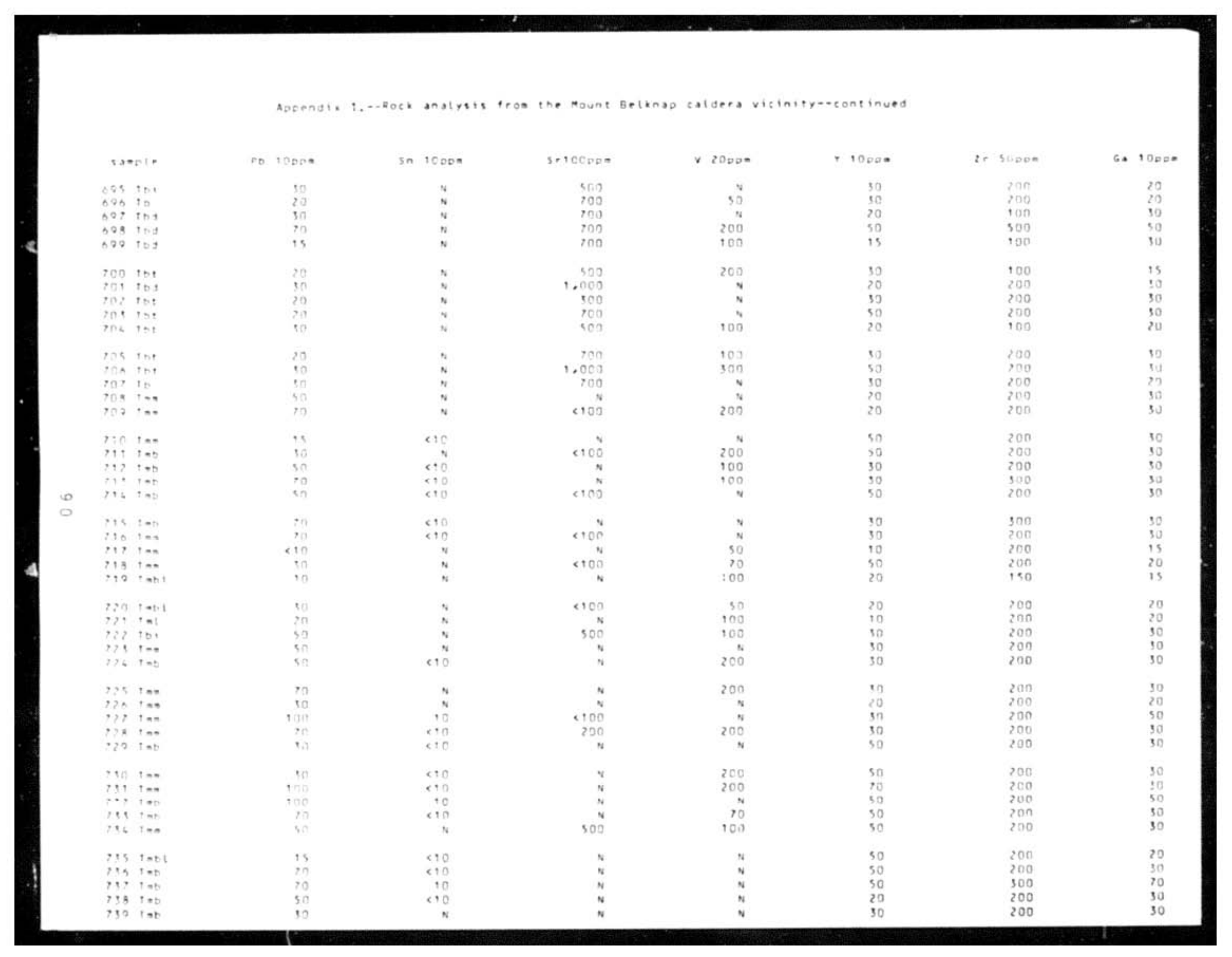




\begin{tabular}{|c|c|c|c|c|c|c|c|c|c|}
\hline $\operatorname{senple}$ & Lat thade & Longitude & $r e .05:$ & $\mathrm{Mg} .02 \mathrm{x}$ & C. .05z & $14.00 \geqslant 2$ & Mn loopen & $A Q .500=$ & B. $2000=$ \\
\hline 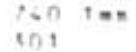 & $\begin{array}{lll}15 & 25 & 26 \\
19 & 25 & 55\end{array}$ & $\begin{array}{llll}112 & 24 & 36 \\
112 & 27 & 50\end{array}$ & $\begin{array}{r}2.00 \\
15: 00\end{array}$ & .30 & .50 & .500 & 2.000 & $\therefore 5$ & $1 n 0$ \\
\hline$\rightarrow 7$ & $15>8>$ & 112225 & $\begin{array}{r}15.00 \\
2.00\end{array}$ & .05 & .05 & -100 & $\operatorname{lno}$ & 2.5 & 200 \\
\hline 303 & 18,245 & 1123245 & 2.00 & $\begin{array}{r}.50 \\
1.00\end{array}$ & $\begin{array}{l}.20 \\
1.00\end{array}$ & $\begin{array}{r}-500 \\
5500\end{array}$ & $\begin{array}{l}500 \\
580\end{array}$ & $\therefore 5$ & 1.000 \\
\hline 106 & 982266 & 1123245 & 1.00 & .10 & $<.05$ & .200 & 150 & $<5$ & 100 \\
\hline 305 & $3321<2$ & 1123947 & מח. & 1.00 & 1.00 & 1.000 & 200 & .7 & 2.000 \\
\hline nos & $38 \geqslant 272$ & 112162 & 15.00 & 1.00 & .20 & 1.000 & 200 & .5 & 1.000 \\
\hline in & $13 \geqslant 60$ & 1123950 & 1.00 & .50 & .05 & .500 & 300 & 2.0 & soo \\
\hline 102 & 3878 & $1, ? 3553$ & .50 & .02 & $<.05$ & .050 & 20 & .5 & 70 \\
\hline 10. & 327556 & 1123516 & 3.00 & 1.00 & .50 & .500 & 700 & .5 & 2,000 \\
\hline :.., & $3528>0$ & $112+3465$ & 3.00 & .20 & .20 & .500 & 200 & 3.0 & 1,500 \\
\hline$\because$ & $3827 \quad 6$ & 1123358 & .05 & .70 & $<.05$ & .20n & 30 & 1.0 & 150 \\
\hline ¿? & 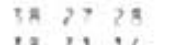 & 1122046 & $\therefore .00$ & .05 & $<.05$ & .200 & 700 & 2.5 & 50 \\
\hline$\because 16$ & \begin{tabular}{llll}
12 & 16 & 16 \\
\hdashline & 38 & 10
\end{tabular} & $1,12,2343$ & .00 & .n? & $<.05$ & .200 & 50 & $n$ & 50 \\
\hline & 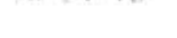 & 年 & .50 & .20 & .05 & .500 & 150 & 2.0 & 500 \\
\hline 18 & $\begin{array}{l}12003 \\
1428 \\
14\end{array}$ & $\begin{array}{llll}117 & 24 & 32 \\
112 & 24 & 57\end{array}$ & 10.00 & 1.00 & 1.00 & $>1.000$ & 500 & $3 . n$ & 2.000 \\
\hline 3,7 & $x$ is 3 & 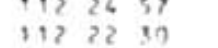 & .50 & .05 & $<.05$ & .010 & 300 & 3.0 & 200 \\
\hline 318 & 392333 & 1122531 & $\begin{array}{r}1.00 \\
.20\end{array}$ & $.3)$ & $\dot{n}^{30}$ & $\begin{array}{l}.200 \\
: 100\end{array}$ & $\begin{array}{l}700 \\
200\end{array}$ & $1: 0$ & $\begin{array}{r}2.000 \\
10\end{array}$ \\
\hline 118 & $\therefore 25<0$ & 1122420 & .05 & .10 & .05 & .100 & 300 & $\therefore 5$ & 50 \\
\hline$\pi 1$ & $1825<?$ & 11217 & 5.00 & 1.00 & .20 & 1.000 & 150 & .5 & 2.000 \\
\hline 20? & $3 \times 205$ & 1123146 & .30 & .50 & 3.00 & .200 & 200 & $<.5$ & 500 \\
\hline en: & 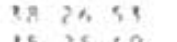 & 1123145 & 2.00 & .50 & 1.00 & .500 & 500 & 5.0 & 500 \\
\hline $80:$ & 147560 & 1123722 & .10 & $<.02$ & $\cos$ & $>1.000$ & 50 & 5.0 & 150 \\
\hline 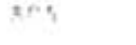 & $0325<0$ & 1123222 & 2.00 & .10 & .10 & .200 & 200 & $<.5$ & 100 \\
\hline$F \cap 0$ & 322457 & $11232 \quad 0$ & $1.0 n$ & 10 & 1.00 & .100 & ino & $<.5$ & 100 \\
\hline$m ?$ & 142532 & 1123242 & 7.00 & 5.00 & 2.00 & 1.000 & $1,0 n \pi$ & 4.5 & 2.000 \\
\hline$\pi=\pi$ & $18253 ?$ & 1125269 & 10.00 & 1.00 & 1.00 & 1.000 & 1,500 & 3.0 & 1.000 \\
\hline .97 & 382629 & 11235.5 & .50 & .50 & .10 & .200 & 150 & $<.5$ & 200 \\
\hline 80 & 182617 & 1129254 & 1.50 & 1.00 & .10 & .500 & 150 & .5 & 1.000 \\
\hline$\$ 19$ & $32>360$ & 1123247 & 10.00 & 3.00 & 5.00 & $>1.000$ & 1,000 & c.s & 2.000 \\
\hline $8 \% 2$ & 382760 & 112325 & . sn & .05 & .05 & .100 & 300 & $<.5$ & 30 \\
\hline N:3 & 372610 & 1123254 & $\therefore .00$ & .20 & .10 & .200 & 500 & $<.5$ & 70 \\
\hline 816 & 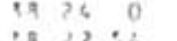 & $1123 ? 52$ & 10.00 & .50 & .05 & 1.000 & 100 & 2.5 & 1.000 \\
\hline 815 & $2827: 6$ & $112 \quad 3157$ & 1.00 & .20 & .10 & .100 & 700 & c.s & \$0 \\
\hline P. & $17>269$ & $1,123: 6$ & $7.0 n$ & 1.00 & .20 & 1.000 & 200 & $N$ & 1.000 \\
\hline A, & 182524 & $1.230<6$ & 1.00 & .07 & .10 & .100 & 500 & $c .5$ & 20 \\
\hline$N=$ & $325 ?$ & $112 \geqslant 258$ & 1. ก० & .20 & .10 & .100 & 20 & -7 & 70 \\
\hline 217 & 32558 & 1123312 & 1.50 & .50 & .05 & .200 & 150 & 2.0 & 300 \\
\hline 821 & 132727 & 1123190 & $\because 00$ & .20 & .50 & .200 & 1.000 & c.s & 70 \\
\hline $8: 2$ & $38: 713$ & $\begin{array}{lll}112 & 51 & 18\end{array}$ & .05 & .20 & 2.00 & .100 & 500 & $n$ & $<20$ \\
\hline 123 & $38>1<7$ & 1123122 & 10.00 & $1 . \mathrm{nn}$ & .50 & 21.000 & 700 & $<.5$ & 1.030 \\
\hline 326 & 382210 & $\because \because 23029$ & 5.00 & .50 & .05 & .500 & 200 & .7 & 1.000 \\
\hline 825 & 382154 & 1123216 & 10.00 & 2.00 & 2.00 & $>1.000$ & 200 & $\therefore 5$ & 2.000 \\
\hline 825 & 382250 & 11253587 & 5.00 & 1.00 & 1.00 & $>1.000$ & 100 & 70.0 & 1.000 \\
\hline
\end{tabular}


appendix 1. - pock anatysis tron the Mount belknap caldera vicinity-econsinued

\begin{tabular}{|c|c|c|c|c|c|c|c|c|}
\hline wate & Be $100 \mathrm{n}$ & to sope & cr $20 \mathrm{pDn}$ & Cu SDD. & Lo 2 Cond & Mo SPDE & No 20000 & $N$ SDD \\
\hline $\begin{array}{ll}760 & 1 \mathrm{me} \\
301 & \\
307 & \\
303 \\
306 & \end{array}$ & $\begin{array}{r}20.0 \\
700 \\
20.0 \\
20.0 \\
15.0\end{array}$ & $\begin{array}{c}n \\
3 \\
3.00 \\
5.00 \\
<5.00\end{array}$ & $\begin{array}{r}20 \\
n \\
30 \\
20 \\
30\end{array}$ & $\begin{array}{l}5 \\
s 5 \\
30 \\
10 \\
15\end{array}$ & $\begin{array}{r}50 \\
150 \\
50 \\
30 \\
50\end{array}$ & $\begin{array}{c}e s \\
n \\
n \\
s \\
5\end{array}$ & $\begin{array}{l}70 \\
30 \\
30 \\
70 \\
20\end{array}$ & $\begin{array}{l}3 \\
3 \\
3 \\
30\end{array}$ \\
\hline $\begin{array}{l}305 \\
300 \\
307 \\
303 \\
300\end{array}$ & $\begin{array}{l}5.0 \\
5: 0 \\
3.0 \\
\because: 5 \\
\because n\end{array}$ & $\begin{array}{r}10.00 \\
20.00 \\
5500 \\
50.00\end{array}$ & $\begin{array}{r}200 \\
150 \\
5 \\
20 \\
50\end{array}$ & $\begin{array}{l}10 \\
70 \\
50 \\
30 \\
30\end{array}$ & $\begin{array}{r}100 \\
50 \\
20 \\
10 \\
90\end{array}$ & $\begin{array}{r}n \\
n \\
20 \\
n \\
c s\end{array}$ & $\begin{array}{r}20 \\
20 \\
20 \\
n \\
N\end{array}$ & $\begin{array}{l}50 \\
50 \\
s 5 \\
s 0 \\
50\end{array}$ \\
\hline 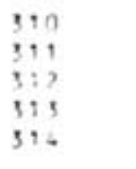 & $\begin{array}{l}80 \\
\because \because 0 \\
20 \\
150 \\
15.0\end{array}$ & $\begin{array}{c}15.00 \\
\vdots \\
n \\
5.00 \\
5.00\end{array}$ & $\begin{array}{r}50 \\
30 \\
<20 \\
n \\
20\end{array}$ & $\begin{array}{c}50 \\
45 \\
4 \\
5 \\
5 \\
10\end{array}$ & $\begin{array}{l}20 \\
n \\
70 \\
70 \\
20\end{array}$ & $\begin{array}{r}15 \\
0 \\
7 \\
n \\
5\end{array}$ & $\begin{array}{r}N \\
N \\
70 \\
50 \\
<20\end{array}$ & $\begin{array}{l}10 \\
13 \\
\text { is } \\
\text { s } \\
7\end{array}$ \\
\hline $\begin{array}{l}315 \\
316 \\
317 \\
319 \\
310\end{array}$ & $\begin{array}{c}50 \\
100 \\
15: 0 \\
3: 0 \\
10.0 \\
10.0\end{array}$ & 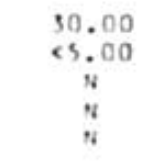 & 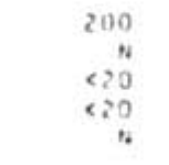 & $\begin{array}{r}70 \\
7 \\
50 \\
: \\
n\end{array}$ & $\begin{array}{r}100 \\
30 \\
30 \\
30 \\
20\end{array}$ & $\begin{array}{r}20 \\
ת \\
n \\
10 \\
n \\
n\end{array}$ & $\begin{array}{r}20 \\
5 \\
50 \\
70 \\
30\end{array}$ & $\begin{array}{l}50 \\
s 3 \\
s \\
s \\
s \\
s\end{array}$ \\
\hline $\begin{array}{l}809 \\
80 ? \\
303 \\
806 \\
805\end{array}$ & $\begin{array}{l}3: n \\
\because \because n \\
\vdots 0 \\
\vdots 0 \\
0\end{array}$ & $\begin{array}{r}7.00 \\
; i .00 \\
3: 00 \\
3.00\end{array}$ & $\begin{array}{r}100 \\
<20 \\
20 \\
30 \\
1 .\end{array}$ & $\begin{array}{r}70 \\
300 \\
300 \\
55 \\
45\end{array}$ & $\begin{array}{l}30 \\
20 \\
10 \\
70 \\
10\end{array}$ & $\begin{array}{r}20 \\
N \\
N \\
70 \\
N\end{array}$ & $\begin{array}{l}20 \\
20 \\
30 \\
30 \\
50\end{array}$ & $\begin{array}{l}30 \\
3 \\
3 \\
3 \\
s \\
s\end{array}$ \\
\hline $\begin{array}{l}808 \\
877 \\
808 \\
810 \\
810\end{array}$ & $\begin{array}{r}15.0 \\
1.0 \\
10.0 \\
1 \% .0 \\
10.0\end{array}$ & $\begin{array}{l}20 \\
20.00 \\
20.00 \\
5500 \\
\$ 5.00\end{array}$ & $\begin{array}{r}100 \\
50 \\
n \\
n \\
n\end{array}$ & $\begin{array}{r}7 \\
70 \\
100 \\
45 \\
7\end{array}$ & $\begin{array}{r}20 \\
70 \\
30 \\
20 \\
100\end{array}$ & $\begin{array}{l}3 \\
? \\
? \\
?\end{array}$ & $\begin{array}{r}20 \\
220 \\
220 \\
70 \\
30\end{array}$ & $\begin{array}{c}N \\
50 \\
50 \\
N \\
N\end{array}$ \\
\hline $\begin{array}{l}81, \\
812 \\
813 \\
816 \\
315\end{array}$ & $\begin{array}{r}3.0 \\
15.0 \\
15.0 \\
5.0 \\
10.0\end{array}$ & 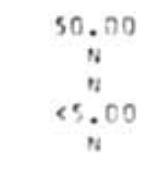 & $\begin{array}{r}300 \\
20 \\
4 \\
50 \\
<20\end{array}$ & $\begin{array}{r}100 \\
5 \\
n \\
50 \\
n\end{array}$ & $\begin{array}{r}100 \\
30 \\
50 \\
30 \\
50\end{array}$ & $\begin{array}{l}s \\
n \\
n \\
n\end{array}$ & $\begin{array}{r}20 \\
30 \\
70 \\
<20 \\
70\end{array}$ & $\begin{array}{c}100 \\
\text { \&s } \\
\text { cs } \\
N \\
N\end{array}$ \\
\hline $\begin{array}{l}816 \\
817 \\
819 \\
819 \\
821\end{array}$ & $\begin{array}{l}2.0 \\
20.0 \\
15.0 \\
10.0 \\
20.0\end{array}$ & $\begin{array}{l}10.00 \\
i n \\
5.00 \\
5.00 \\
<5.00\end{array}$ & $\begin{array}{r}5 n 0 \\
n \\
n \\
20 \\
<20\end{array}$ & $\begin{array}{r}150 \\
45 \\
5 \\
15 \\
45\end{array}$ & $\begin{array}{l}50 \\
30 \\
10 \\
20 \\
10\end{array}$ & $\begin{array}{l}30 \\
N \\
13 \\
30 \\
15\end{array}$ & $\begin{array}{r}20 \\
50 \\
50 \\
20 \\
70\end{array}$ & $\begin{array}{l}30 \\
\text { ss } \\
\text { is } \\
\text { s } \\
\text { cs }\end{array}$ \\
\hline $\begin{array}{l}82 ? \\
823 \\
876 \\
825 \\
826\end{array}$ & $\begin{array}{r}150 \\
3: 0 \\
5: 0 \\
7: 0 \\
7: 0\end{array}$ & $\begin{array}{r}30 \\
500 \\
5.00 \\
10.00 \\
7.00\end{array}$ & $\begin{array}{l}100 \\
200 \\
200 \\
20\end{array}$ & $\begin{array}{l}70 \\
70 \\
30 \\
70 \\
50\end{array}$ & $\begin{array}{r}20 \\
50 \\
10 \\
100 \\
100 \\
100\end{array}$ & $\begin{array}{c}3 \\
s \\
7 \\
n \\
5\end{array}$ & $\begin{array}{r}30 \\
20 \\
30 \\
620 \\
20\end{array}$ & $\begin{array}{l}15 \\
50 \\
<5 \\
30 \\
3\end{array}$ \\
\hline
\end{tabular}


Appendix 1... Pock analysis from the Mount Betknap caldera visinityo-cont inved

\begin{tabular}{|c|c|c|c|c|c|c|c|}
\hline vander & Po 1000 . & sn $1000 \mathrm{pm}$ & seroome & v $2000=$ & r 10000 & 20 snowe & Go 10000 \\
\hline $\begin{array}{lll}760 \\
3 n \\
307 \\
303 \\
304 \\
304\end{array}$ & $\begin{array}{l}30 \\
50 \\
50 \\
30 \\
30\end{array}$ & 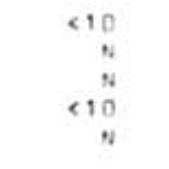 & $\begin{array}{r}n \\
n \\
5 n 0 \\
190 \\
n \\
n\end{array}$ & $\begin{array}{r}N \\
n \\
100 \\
100 \\
100\end{array}$ & $\begin{array}{r}50 \\
100 \\
30 \\
50 \\
30\end{array}$ & $\begin{array}{l}200 \\
100 \\
200 \\
200 \\
200\end{array}$ & $\begin{array}{l}30 \\
15 \\
20 \\
30 \\
30\end{array}$ \\
\hline $\begin{array}{l}305 \\
306 \\
307 \\
308 \\
300\end{array}$ & $\begin{array}{l}30 \\
30 \\
10 \\
10 \\
10\end{array}$ & $\begin{array}{l}n \\
n \\
n \\
n\end{array}$ & 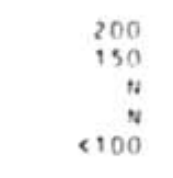 & $\begin{array}{r}200 \\
200 \\
50 \\
n \\
100\end{array}$ & $\begin{array}{r}30 \\
30 \\
10 \\
10 \\
30 \\
30\end{array}$ & $\begin{array}{l}300 \\
200 \\
200 \\
100 \\
200\end{array}$ & $\begin{array}{l}30 \\
30 \\
10 \\
N \\
10\end{array}$ \\
\hline $\begin{array}{l}3: 0 \\
311 \\
3: 2 \\
313 \\
314\end{array}$ & $\begin{array}{r}30 \\
30 \\
30 \\
30 \\
<10\end{array}$ & "n & $\begin{array}{r}200 \\
n \\
n \\
n \\
100\end{array}$ & $\begin{array}{r}100 \\
70 \\
v \\
N \\
n\end{array}$ & $\begin{array}{r}15 \\
410 \\
50 \\
20 \\
810\end{array}$ & $\begin{array}{l}200 \\
10 \\
200 \\
200 \\
200\end{array}$ & $\begin{array}{r}15 \\
410 \\
30 \\
10 \\
10 \\
n\end{array}$ \\
\hline 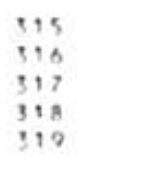 & $\begin{array}{r}50 \\
15 \\
100 \\
n \\
30\end{array}$ & $\begin{array}{l}n \\
n \\
n \\
n \\
n\end{array}$ & $\begin{array}{r}r 00 \\
n \\
150 \\
r 100 \\
N\end{array}$ & $\begin{array}{r}500 \\
N \\
n \\
n \\
N\end{array}$ & $\begin{array}{l}50 \\
n \\
20 \\
30 \\
30\end{array}$ & $\begin{array}{l}500 \\
850 \\
200 \\
200 \\
200\end{array}$ & $\begin{array}{r}50 \\
50 \\
10 \\
30 \\
15 \\
15\end{array}$ \\
\hline $\begin{array}{l}0,0, \\
80 ? \\
803 \\
806 \\
\text { nos }\end{array}$ & $\begin{array}{r}30 \\
30 \\
100 \\
50 \\
50\end{array}$ & $\begin{array}{c}n \\
n \\
30 \\
3 \\
n\end{array}$ & $\begin{array}{r}100 \\
3.000 \\
200 \\
<00 \\
n\end{array}$ & $\begin{array}{r}200 \\
100 \\
200 \\
40\end{array}$ & $\begin{array}{r}30 \\
30 \\
30 \\
10 \\
50\end{array}$ & $\begin{array}{l}200 \\
200 \\
200 \\
50 \\
200\end{array}$ & $\begin{array}{l}20 \\
15 \\
30 \\
n \\
20\end{array}$ \\
\hline $\begin{array}{l}801 \\
807 \\
808 \\
808 \\
817\end{array}$ & $\begin{array}{r}150 \\
15 \\
30 \\
50 \\
70\end{array}$ & $\begin{array}{l}n \\
n \\
n \\
n \\
n\end{array}$ & $\begin{array}{r}<100 \\
700 \\
100 \\
n 0 \\
300\end{array}$ & $\begin{array}{r}200 \\
200 \\
50 \\
50\end{array}$ & $\begin{array}{l}10 \\
31 \\
30 \\
30 \\
30\end{array}$ & $\begin{array}{l}100 \\
200 \\
200 \\
300 \\
300\end{array}$ & $\begin{array}{l}50 \\
30 \\
15 \\
15 \\
30\end{array}$ \\
\hline $\begin{array}{l}51, \\
812 \\
8,3 \\
51, \\
k 15\end{array}$ & $\begin{array}{l}30 \\
20 \\
50 \\
20 \\
20\end{array}$ & \begin{tabular}{r}
$n$ \\
$n$ \\
0 \\
\hdashline \\
0
\end{tabular} & $\begin{array}{r}1.000 \\
N \\
N \\
n \\
400\end{array}$ & $\begin{array}{r}500 \\
N \\
200 \\
N\end{array}$ & $\begin{array}{l}30 \\
15 \\
30 \\
20 \\
30\end{array}$ & $\begin{array}{l}300 \\
100 \\
200 \\
200 \\
200\end{array}$ & $\begin{array}{l}30 \\
10 \\
30 \\
20 \\
20\end{array}$ \\
\hline $\begin{array}{l}R 16 \\
817 \\
81, \\
810 \\
B=1\end{array}$ & $\begin{array}{r}10 \\
310 \\
70 \\
<10 \\
70\end{array}$ & $\begin{array}{l}* \\
4 \\
N \\
n \\
0\end{array}$ & $\begin{array}{r}100 \\
N \\
N \\
100 \\
100\end{array}$ & $\begin{array}{r}500 \\
N \\
N \\
20 \\
N\end{array}$ & $\begin{array}{l}30 \\
50 \\
30 \\
10 \\
50\end{array}$ & $\begin{array}{l}500 \\
200 \\
200 \\
200 \\
200\end{array}$ & $\begin{array}{r}30 \\
15 \\
15 \\
10 \\
50\end{array}$ \\
\hline $\begin{array}{l}822 \\
823 \\
8 \geq 6 \\
825 \\
826\end{array}$ & $\begin{array}{r}30 \\
20 \\
20 \\
30 \\
150\end{array}$ & $\begin{array}{l}n \\
n \\
n \\
n \\
n\end{array}$ & $\begin{array}{r}150 \\
100 \\
400 \\
150 \\
200\end{array}$ & $\begin{array}{l}20 \\
200 \\
100 \\
200 \\
100\end{array}$ & $\begin{array}{l}30 \\
30 \\
30 \\
30 \\
30\end{array}$ & $\begin{array}{l}100 \\
200 \\
500 \\
200 \\
500\end{array}$ & $\begin{array}{l}30 \\
20 \\
30 \\
30 \\
20\end{array}$ \\
\hline
\end{tabular}




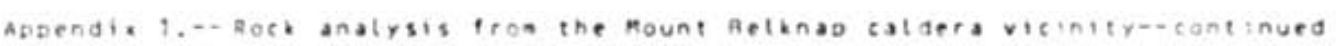

\begin{tabular}{|c|c|c|c|c|c|c|c|c|c|}
\hline$\ldots=1-$ & tasterese & Longutude & 2. . .052 & no . o z z & Cs. .0s: & " & mo $100 \mathrm{pm}$ & Ag. 5000 & B. 2000 as \\
\hline 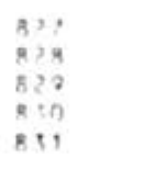 & $\begin{array}{llll}39 & 23 & 4 \\
38 & 28 & 42 \\
10 & 26 & 30 \\
18 & 28 & 31 \\
19 & 26 & 27\end{array}$ & 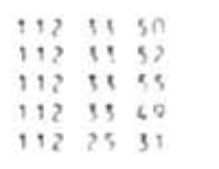 & $\begin{array}{l}1.00 \\
10.00 \\
.05 \\
.00\end{array}$ & $\begin{array}{l}.50 \\
0.02 \\
030 \\
90 \\
10 \\
10\end{array}$ & $\begin{array}{r}.05 \\
: 00 \\
200 \\
.05 \\
.05\end{array}$ & $\begin{array}{l}1.000 \\
\because, 002 \\
: 509 \\
: 100 \\
.200\end{array}$ & $\begin{array}{r}70 \\
20 \\
180 \\
20 \\
200\end{array}$ & $\begin{array}{r}: 7 \\
\because 5 \\
: 7\end{array}$ & $\begin{array}{r}1.500 \\
50 \\
2.000 \\
500 \\
50\end{array}$ \\
\hline $\begin{array}{l}839 \\
3: 3 \\
315 \\
815 \\
913\end{array}$ & $\begin{array}{llll}3 & 33 & 3 \\
3 * & 32 & 3 \\
34 & 22 & 32 \\
38 & 26 & 53 \\
10 & 36 & 31\end{array}$ & 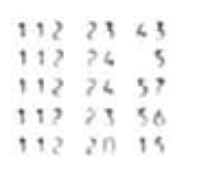 & $\begin{array}{l}? .00 \\
5.00 \\
2.00 \\
\because .00 \\
2.00\end{array}$ & $\begin{array}{l}2.00 \\
2.00 \\
.10 \\
.10 \\
.10\end{array}$ & $\begin{array}{l}3.00 \\
3.00 \\
\therefore .20 \\
\because 05 \\
.00\end{array}$ & $\begin{array}{l}1.000 \\
: 500 \\
: 5 n 0 \\
: 230 \\
.010\end{array}$ & $\begin{array}{r}500 \\
1,000 \\
1,000 \\
300 \\
150\end{array}$ & $\begin{array}{r}\because 5 \\
3: 0 \\
300.5\end{array}$ & $\begin{array}{r}1.500 \\
2.000 \\
100 \\
30 \\
2.000\end{array}$ \\
\hline $\begin{array}{l}860 \\
84 \\
8: 2 \\
8: 3 \\
866\end{array}$ & $\begin{array}{llll}38 & 24 & 48 \\
18 & 78 & 56 \\
18 & 28 & 5 \\
10 & 27 & 4 \\
3 \pi & 27 & 5\end{array}$ & 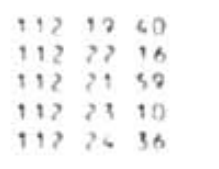 & $\begin{array}{r}10.00 \\
7.00 \\
7.00 \\
: 50 \\
1.00\end{array}$ & $\begin{array}{l}2.00 \\
\because .00 \\
500 \\
2.20 \\
200\end{array}$ & $\begin{array}{l}: 50 \\
: 50 \\
: 200 \\
: 50 \\
50\end{array}$ & $\begin{array}{l}.503 \\
\therefore, 000 \\
: 500 \\
: 000 \\
1.000\end{array}$ & $\begin{array}{r}1,5 n 0 \\
300 \\
500 \\
50 \\
100\end{array}$ & $\begin{array}{l}000 \\
\because: 0 \\
3: 0\end{array}$ & $\begin{array}{l}2.600 \\
1.500 \\
1.000 \\
1.500 \\
2.000\end{array}$ \\
\hline $\begin{array}{l}3<5 \\
3<5 \\
967 \\
968 \\
8<8\end{array}$ & $\begin{array}{ccc}13 & 28 & 60 \\
38 & 22 & 52 \\
38 & 27 & 28 \\
38 & 73 & 9 \\
31 & 25 & 9\end{array}$ & $\begin{array}{lll}112 & 26 & 3 \\
112 & 23 & 33 \\
112 & 22 & 23 \\
112 & 21 & 33 \\
112 & 26 & 32\end{array}$ & $\begin{array}{l}.70 \\
2.00 \\
7.00 \\
5.00 \\
1.00\end{array}$ & $\begin{aligned} .50 \\
.50 \\
.20 \\
.50 \\
.50 \\
.10\end{aligned}$ & $\begin{aligned} & \therefore 10 \\
& 100 \\
& 100 \\
& .05 \\
& .10\end{aligned}$ & $\begin{array}{r}.500 \\
1.000 \\
1.000 \\
: 500 \\
.100\end{array}$ & $\begin{array}{l}300 \\
150 \\
50 \\
500 \\
200\end{array}$ & $\begin{array}{l}3: 0 \\
i s \\
i s \\
i: 5 \\
i . s\end{array}$ & $\begin{array}{r}1.000 \\
2.000 \\
2.000 \\
300 \\
30\end{array}$ \\
\hline
\end{tabular}




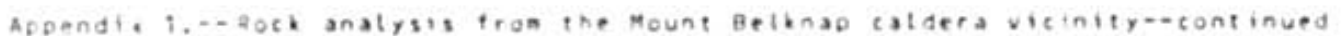

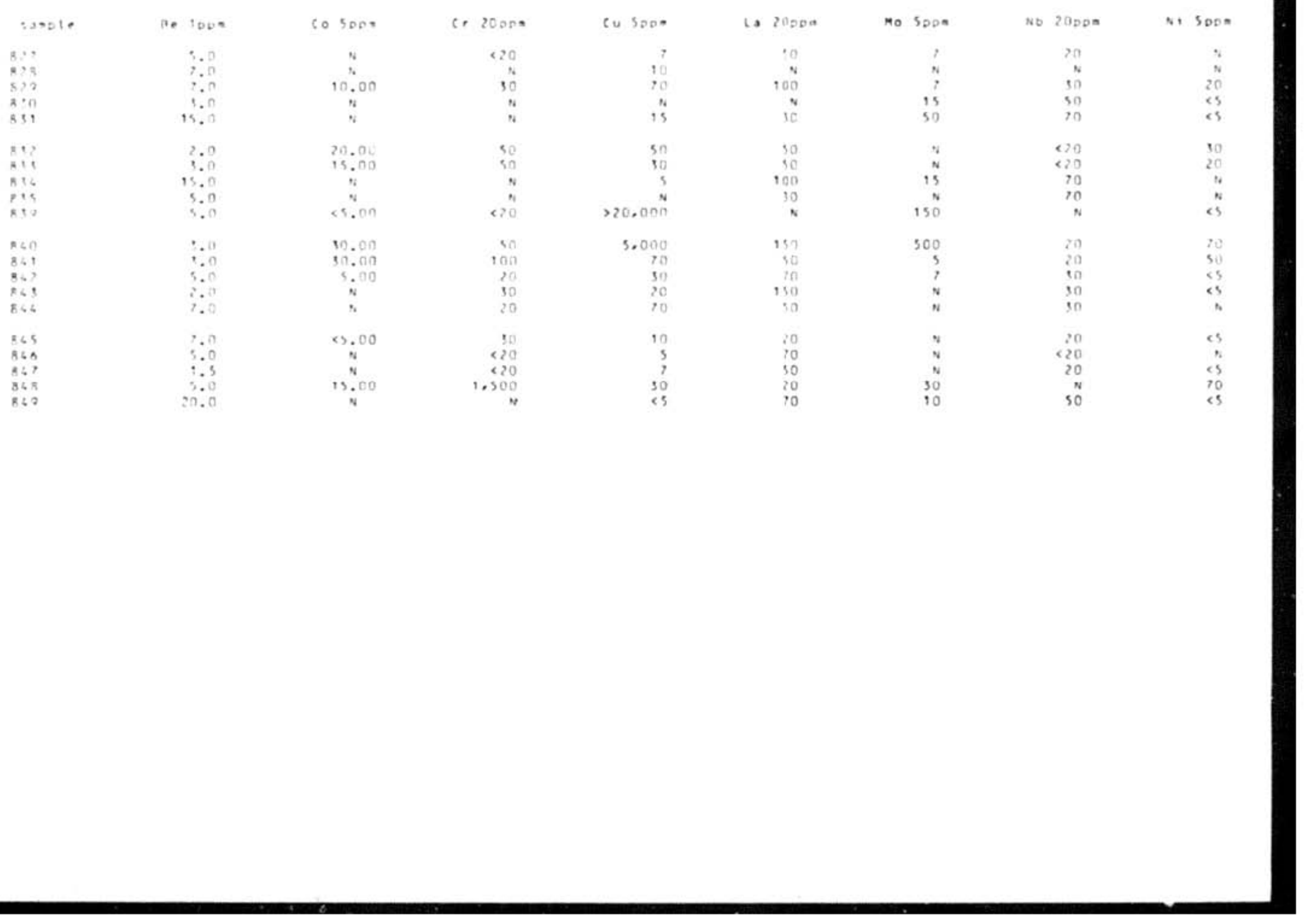




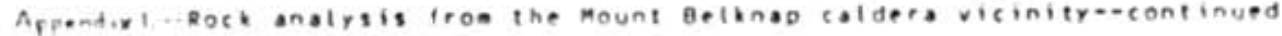

\begin{tabular}{|c|c|c|c|c|c|c|c|}
\hline 5,0010 & on 10000 & sn 10000 & stronoos & $\times 20000$ & , $10 \mathrm{~s}$ & $2+50000$ & 6. 10000 \\
\hline $\begin{array}{l}827 \\
8218\end{array}$ & 50 & 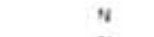 & 300 & 70 & $7 \pi$ & 200 & 20 \\
\hline $\begin{array}{l}82 \% \\
R>0\end{array}$ & $n$ & $N$ & $N$ & $n$ & $n$ & $n$ & $N$ \\
\hline 830 & 50 & $n$ & 700 & 200 & 90 & 500 & 20 \\
\hline 831 & 50 & 610 & 100 & $N$ & 10 & 200 & 15 \\
\hline $13 ?$ & 70 & $<10$ & $*$ & N & 10 & 300 & 10 \\
\hline 835 & $\begin{array}{l}20 \\
10\end{array}$ & $N$ & 100 & 100 & 20 & 100 & 20 \\
\hline $8 \times 6$ & $\begin{array}{r}50 \\
150\end{array}$ & $N$ & 500 & $2 n o$ & 20 & 200 & 20 \\
\hline 835 & $\begin{array}{r}150 \\
N\end{array}$ & 10 & סחו & $N$ & 50 & 300 & 50 \\
\hline 830 & 20.0000 & $n$ & $n$ & $n$ & is & $3 n \pi$ & 20 \\
\hline$A<\pi$ & & N & $N$ & $"$ & \% & N & 10 \\
\hline 861 & סצסח, 200 & 10 & «100 & 500 & 50 & 200 & 50 \\
\hline 862 & $\begin{array}{l}30 \\
30\end{array}$ & $N$ & 500 & 200 & 30 & 200 & 20 \\
\hline$A<3$ & $\begin{array}{l}30 \\
30\end{array}$ & N & 300 & 100 & 30 & 300 & 20 \\
\hline 166 & $\begin{array}{l}30 \\
70\end{array}$ & $n$ & 500 & 100 & 10 & 500 & 30 \\
\hline & & N & 500 & 100 & 30 & 300 & 30 \\
\hline 868 & $\begin{array}{l}20 \\
50\end{array}$ & N & 150 & $<20$ & 10 & 200 & $<10$ \\
\hline 867 & $\begin{array}{l}50 \\
30\end{array}$ & N & 500 & 100 & 20 & 200 & 20 \\
\hline 868 & $\begin{array}{l}30 \\
10\end{array}$ & N & 150 & 50 & 30 & 200 & 20 \\
\hline 10 & $\begin{array}{l}10 \\
70\end{array}$ & N & $<100$ & 200 & 10 & 200 & 20 \\
\hline & 70 & 10 & $N$ & $N$ & 30 & 200 & 20 \\
\hline
\end{tabular}


Aspendix 2,..E: ements nitr fewer than 15 reported values
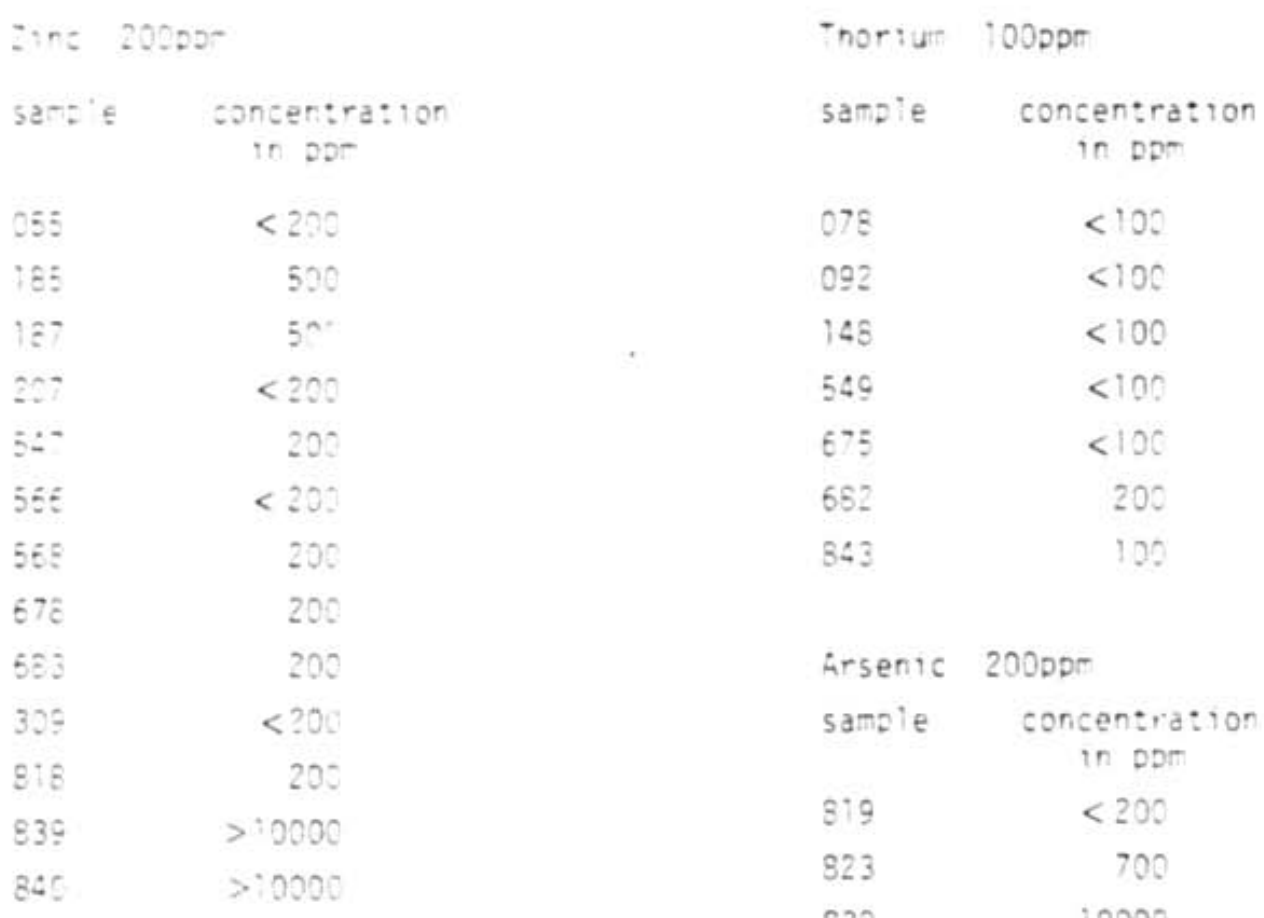

Arsenic 200Dpr

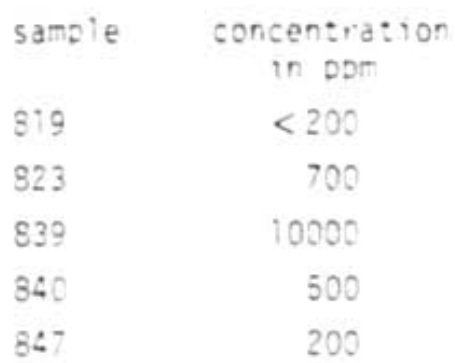

Sismush 1000

sansle concerisa:ior

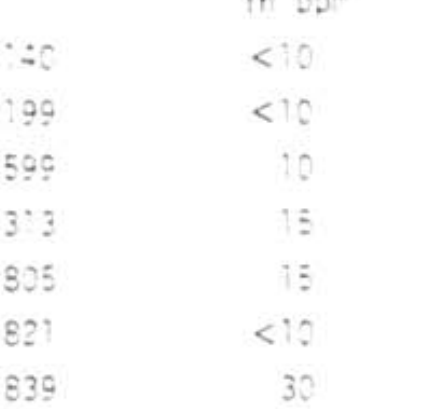

Turgster 50por

sample concentration
in DDM

$301<50$

823

50

839

$<50$

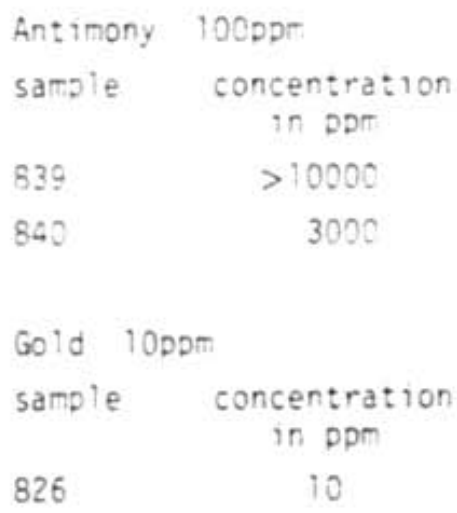

Cadriut 2000r

samile concentration

in DDF

sis $<20$

$842 \quad 500$

Sold iOpDT

in ppm

$826-10$ 